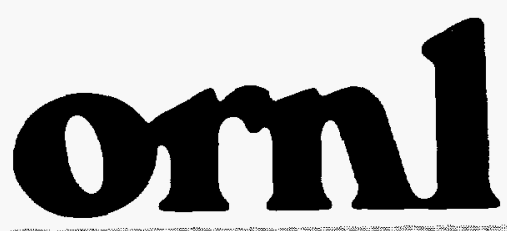

OAK RIDGE NATIONAL. LABORATORY

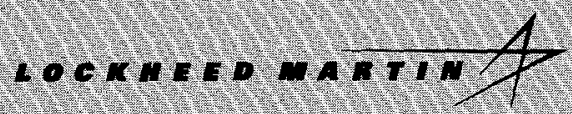
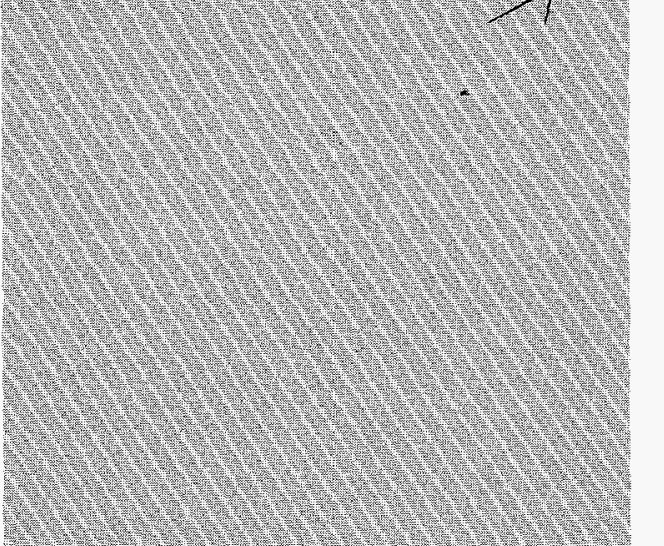

ORNL/TM-13026

\title{
Thermal Analysis to Support Decommissioning of the Molten Salt Reactor Experiment
}

\author{
Authors \\ C. D. Sulfredge \\ D. G. Morris \\ J. E. Park \\ P. T. Williams \\ Other Contributors \\ R. N. Borum \\ D. W. Ramey \\ G. L. Yoder

\section{MASTER}




\section{DISCLAIMER}

This report was prepared as an account of work sponsored by an agency of the United States Government. Neither the United States Government nor any agency thereof, nor any of their employees, makes any warranty. express or implied, or assumes any legal liability or responsibility for the accuracy, completeness, or usefulness of any information, apparatus, product, or process disclosed, or represents that its use would not infringe privately owned rights. Reference herein to any specific commercial product, process, or service by trade name, trademark, manufacturer, or otherwise, does not necessarily constitute or imply its endorsement,

recommendation, or favoring by the United States Government or any agency thereof. The views and opinions of authors expressed herein do not necessarily state or reflect those of the United States Government or any agency thereof. 


\section{DISCLAIMER}

Portions of this document may be illegible in electronic image products. Images are produced from the best available original document. 
ORNL/TM-13026

Dist. Category UC-902

Engineering Technology Division

\title{
THERMAL ANALYSIS TO SUPPORT DECOMMISSIONING OF THE MOLTEN SALT REACTOR EXPERIMENT
}

\author{
Authors \\ C. D. Sulfredge \\ D. G. Morris \\ J. E. Park \\ P. T. Williams \\ Other Contributors \\ R. N. Borum \\ D. W. Ramey \\ G. L. Yoder
}

Date Published: June 1996

\author{
Prepared by the \\ OAK RIDGE NATIONAL LABORATORY \\ Oak Ridge, Tennessee 37831 \\ managed by \\ LOCKHEED MARTIN ENERGY RESEARCH CORP. \\ for the \\ U.S. DEPARTMENT OF ENERGY \\ under contract DE-AC05-96OR22464
}


• 


\section{CONTENTS}

\section{Page}

LIST OF FIGURES $\ldots \ldots \ldots \ldots \ldots \ldots \ldots \ldots \ldots \ldots \ldots \ldots \ldots \ldots \ldots \ldots \ldots \ldots$

LIST OF TABLES $\ldots \ldots \ldots \ldots \ldots \ldots \ldots \ldots \ldots \ldots \ldots \ldots \ldots \ldots \ldots \ldots \ldots \ldots \ldots \ldots \ldots \ldots \ldots$

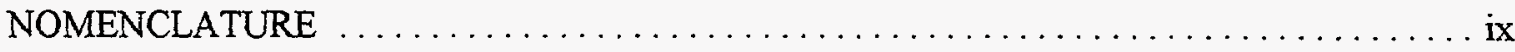

ACKNOWLEDGMENTS $\ldots \ldots \ldots \ldots \ldots \ldots \ldots \ldots \ldots \ldots \ldots \ldots \ldots \ldots \ldots \ldots \ldots \ldots$

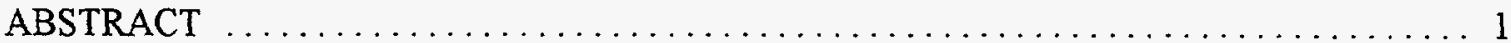

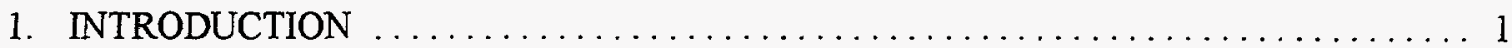

1.1 THE MOLTEN SALT REACTOR EXPERIMENT $\ldots \ldots \ldots \ldots \ldots \ldots \ldots \ldots \ldots$

1.2 BACKGROUND OF THE MSRE PROBLEM $\ldots \ldots \ldots \ldots \ldots \ldots \ldots \ldots \ldots \ldots \ldots$

1.3 DESCRIPTION OF THE ACB GEOMETRY $\ldots \ldots \ldots \ldots \ldots \ldots \ldots \ldots \ldots . \ldots$

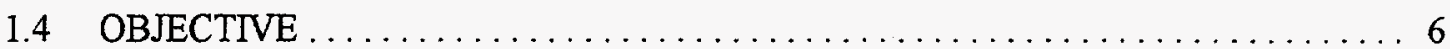

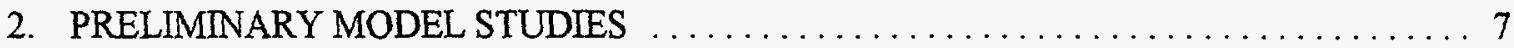

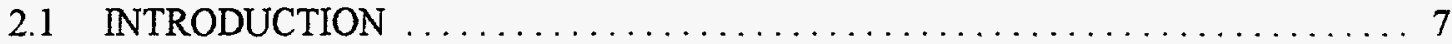

2.2 PRELIMINARY MODEL OF ACB ASSEMBLY $\ldots \ldots \ldots \ldots \ldots \ldots \ldots \ldots \ldots$

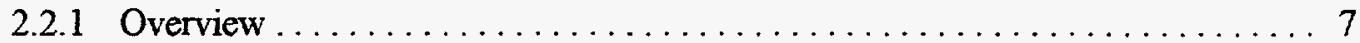

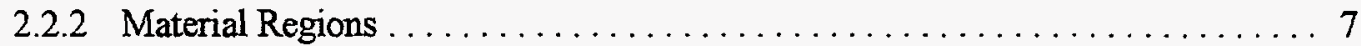

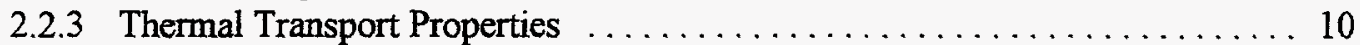

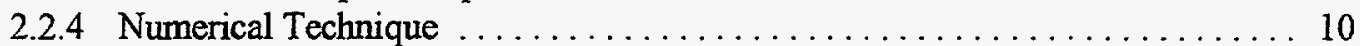

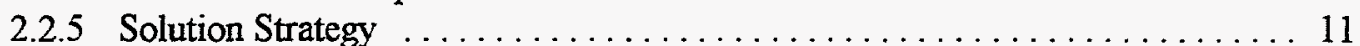

2.3 PRELIMINARY MSRE ACB 2-D THERMAL ANALYSIS RESULTS $\ldots \ldots \ldots \ldots 11$

2.4 UPDATE ON MSRE ACB PRELIMINARY THERMAL ANALYSIS $\ldots \ldots \ldots \ldots .12$

2.5 THERMAL CONDUCTIVITY OF STEEL MESH $\ldots \ldots \ldots \ldots \ldots \ldots \ldots \ldots \ldots$

2.6 USING MEASURED WATER TEMPERATURES AS BOUNDARY

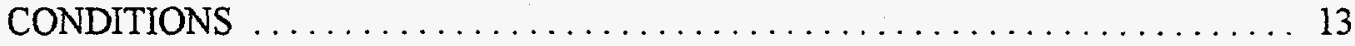

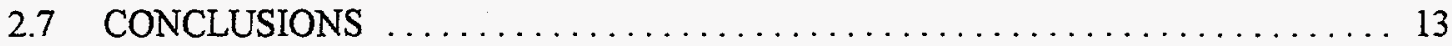

3. DEVELOPMENT AND TESTING OF THERMOCOUPLE PROBE FOR

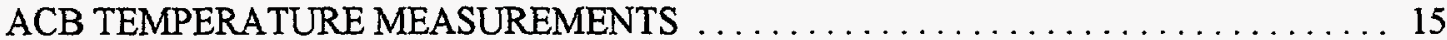

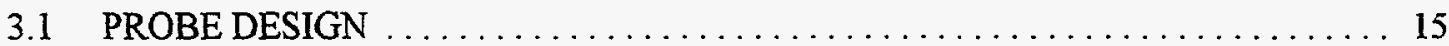

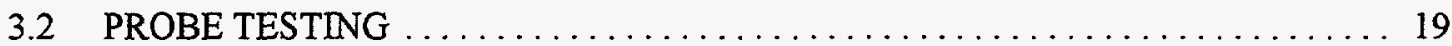

4. HEATING7 MODELS TO SUPPORT DRAINING OF THE CHARCOAL BED $\ldots \ldots \ldots 23$

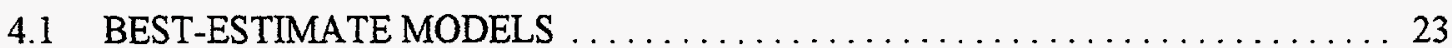

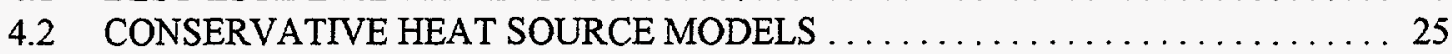

5. HEATING7 MODELS TO SUPPORT FILLING THE CHARCOAL BED CELL . . . . 39

5.1 REFINEMENT OF THE HEAT SOURCE ....................... 39

5.2 FILLING THE CBC WITH $\mathrm{CO}_{2}$ OR VERMICULITE $\ldots \ldots \ldots \ldots \ldots \ldots \ldots . \ldots 1$ 
6. VERIFICATION AND BENCHMARKING OF HEATING MODELS $\ldots \ldots \ldots \ldots \ldots .47$

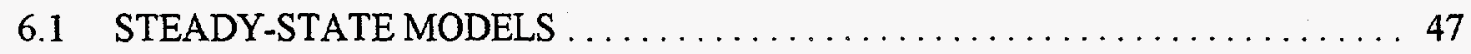

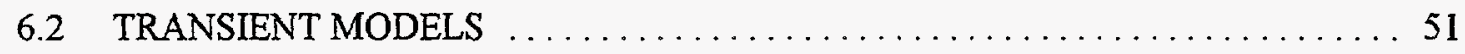

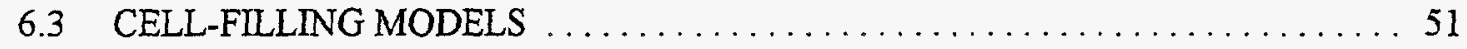

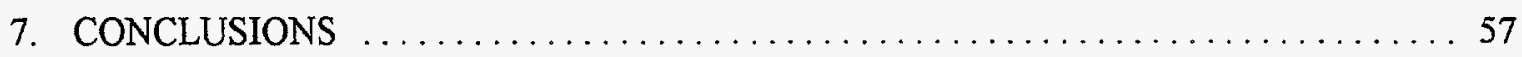

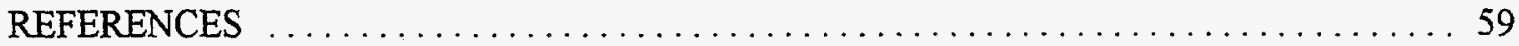

Appendix A. SAMPLE FINALIZED HEATING7.2 MODEL $\ldots \ldots \ldots \ldots \ldots \ldots \ldots \ldots \ldots$ 


\section{LIST OF FIGURES}

Figure

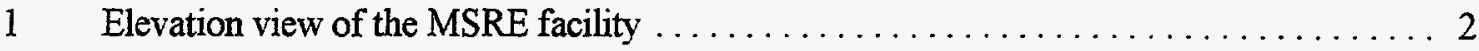

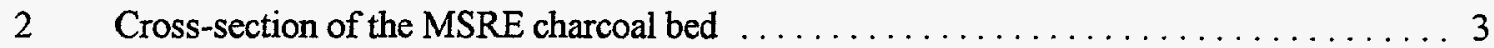

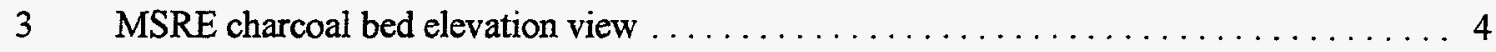

4 Schematic of the charcoal column contaminated with uranium $\ldots \ldots \ldots \ldots \ldots \ldots$

5 Temperature and radiation surveys of the MSRE charcoal bed $\ldots \ldots \ldots \ldots \ldots \ldots$

6 (a) Schematic of a typical HEATING7.2 model and thermal boundary conditions

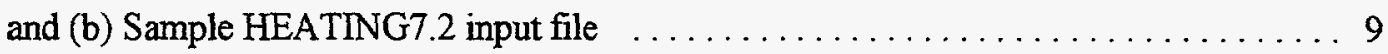

7 Bed centerline temperature for various mesh discretizations $\ldots \ldots \ldots \ldots \ldots \ldots \ldots \ldots$

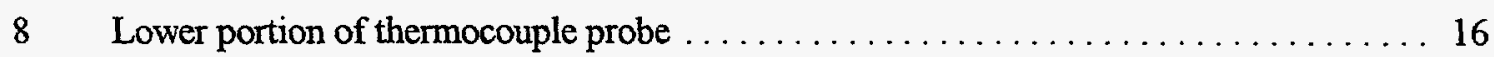

9 Application of thermocouple probe at the MSRE $\ldots \ldots \ldots \ldots \ldots \ldots \ldots \ldots \ldots \ldots$

10 Configuration of mock-up experiment .......................... 20

11 Selected water, pinged-wall, and probe thermocouple readings showing the significant offset error associated with the probe without pin insulation $\ldots \ldots \ldots 22$

12 Selected water, pinged-wall, and probe thermocouple readings showing the reduced offset error associated with the probe with suction cup insulation

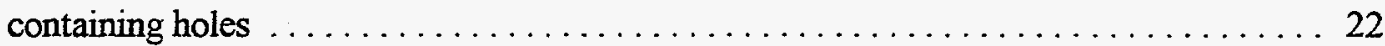

13 Comparison of the calculated best-estimate temperature profile to the raw

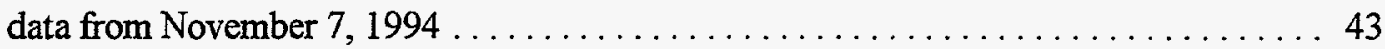

14 Comparison of the calculated best-estimate profile to the split junction data after bias and offset correction . . . . . . . . . . . . . . . . . . . 43

15 Schematic of the $\mathrm{CBC}$ geometry analyzed for the $\mathrm{CO}_{2}$ case $\ldots \ldots \ldots \ldots \ldots \ldots \ldots 4$

16 Schematic of the CBC geometry analyzed for the vermiculite case . . . . . . . . . . 44

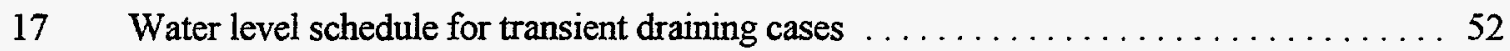

18 Comparison of HEATING7.2 and CFDS-FLOW3D best-estimate

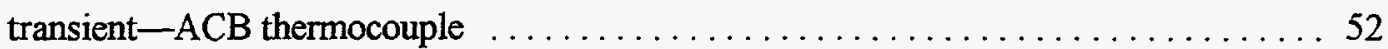

A.1 (a) Schematic of a finalized, best-estimate HEATING7.2 model showing the initial waterline and $\mathrm{ACB} 1-1$ thermowell $\ldots \ldots \ldots \ldots \ldots \ldots \ldots \ldots \ldots \ldots \ldots \ldots \ldots$

(b) HEATING7.2 input file for the model in Fig. A.1a $\ldots \ldots \ldots \ldots \ldots \ldots \ldots$ 
$\checkmark$ 


\section{LIST OF TABLES}

Table

Page

1 Summary of preliminary ACB 2-D thermal analysis results $\ldots \ldots \ldots \ldots \ldots \ldots \ldots 12$

2 Results of the October 7, 1994, ACB wall temperature measurements . . . . . . . . 23

3 Best-estimate steady-state temperatures at each state of draining the $\mathrm{ACB}$,

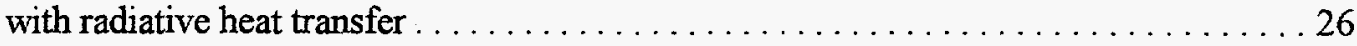

4 Best-estimate transient temperatures $1 \mathrm{~h}$ after reaching each state of draining the $A C B$, with radiative heat transfer $\ldots \ldots \ldots \ldots \ldots \ldots \ldots \ldots$

5 Best-estimate transient temperatures $2 \mathrm{~h}$ after reaching each state of

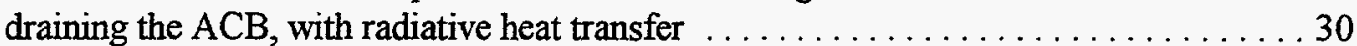

6 Conservative steady-state temperatures at each state of draining the $\mathrm{ACB}$, with radiative heat transfer [assumes a uniformly distributed heat generation rate $(54.4 \mathrm{~W})$ which results in reaching the $100^{\circ} \mathrm{C}$

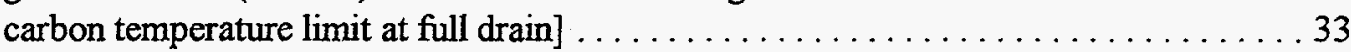

7 Conservative transient temperatures $\mathrm{i} \mathrm{h}$ after reaching each state of draining the $A C B$, with radiative heat transfer [assumes a uniformly distributed heat generation rate $(54.4 \mathrm{~W})$ which results in reaching the $100^{\circ} \mathrm{C}$ carbon temperature limit at full drain] . . . . . . . . . . . . . . . . . . . 35

8 Best-estimate steady-state temperatures at each state of draining the ACB, with radiative heat transfer based on temperature measurements during the drain . . . . . 37

9 ACB temperature profile as measured in air on November $7,1994 \ldots \ldots \ldots \ldots \ldots 40$

10 Creation of new best-estimate and conservative heat generation cases based on the November 7, 1994, temperature measurements . . . . . . . . . . . . . 42

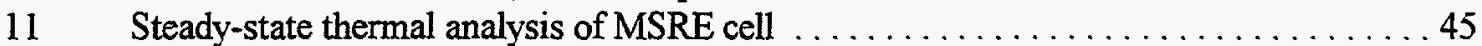

12 CFDS-FLOW3D best-estimate steady-state temperatures at each state of draining the ACB

13 CFDS-FLOW3D conservative steady-state temperatures at each state of

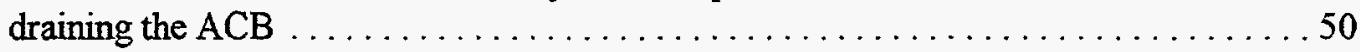

14 Maximum steady-state carbon temperature for $\mathrm{ACB}$ filled with air or $\mathrm{CO}_{2} \ldots \ldots \ldots 51$

15 CFDS-FLOW3D best-estimate transient temperatures at each state

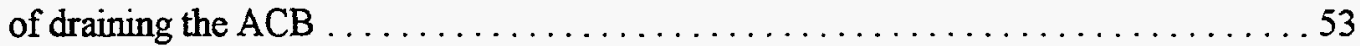

16 CFDS-FLOW3D conservative transient temperatures at each state of

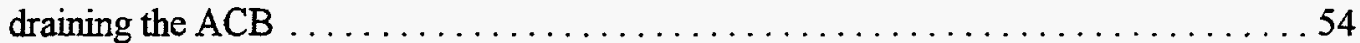

17 Comparison of HEATING7.2 and TOPAZ results for cell-filling models $\ldots \ldots \ldots \ldots 5$ 



\title{
NOMENCLATURE
}

\author{
$A \quad$ Surface area $\left(\mathrm{ft}^{2}\right)$ \\ $g \quad$ Acceleration due to gravity $\left(=32.2 \mathrm{ft} / \mathrm{s}^{2}\right)$ \\ $G r_{x} \quad$ Grashof number $\left[g \beta\left(T_{s}-T_{\infty}\right) x^{3} / v^{2}\right]$ \\ $h \quad$ Convective heat transfer coefficient $\left(\mathrm{Btu} / \mathrm{h}-\mathrm{ft}^{2}-{ }^{\circ} \mathrm{F}\right)$ \\ $k_{f} \quad$ Fluid thermal conductivity (Btu/h-ft- ${ }^{\circ} \mathrm{F}$ ) \\ $L \quad$ Heated length (ft) \\ $\mathrm{Nu} \quad$ Nusselt number $\left(h L / k_{f}\right)$ \\ $\operatorname{Pr} \quad$ Prandtl number $(v / \alpha)$ \\ $q \quad$ Heat transfer rate $(\mathrm{Btu} / \mathrm{h})$ \\ $Q \quad$ Internal volumetric heat generation $\left(\mathrm{Btu} / \mathrm{h}-\mathrm{ft}^{3}\right)$ \\ $R a_{L} \quad$ Rayleigh Number $\left[g \beta\left(T_{s}-T_{\infty}\right) L^{3} / \alpha v\right]$ \\ $T \quad$ Temperature $\left({ }^{\circ} \mathrm{F}\right)$ \\ $V \quad$ Volume $\left(\mathrm{ft}^{3}\right)$ \\ $x \quad$ Axial length coordinate (ft) \\ $y \quad$ Normal length coordinate $(\mathrm{ft})$ \\ Greek Symbols

$\begin{array}{ll}\alpha & \text { Thermal diffusivity }\left(\mathrm{ft}^{2} / \mathrm{h}\right) \\ \beta & \text { Thermal expansion coefficient }\left(1 /{ }^{\circ} \mathrm{R}\right) \\ \delta & \text { Thermal boundary layer thickness }(\mathrm{ft}) \\ \varepsilon & \text { Average surface emissivity } \\ \eta & \text { Natural convection similarity parameter } \\ \nu & \text { Kinematic viscosity }\left(\mathrm{ft}^{2} / \mathrm{h}\right)\end{array}$

Subscripts

av

gen

$L$

$s$

tot

$x$

$\infty$

Average

Generation rate

Heated length

Surface

Total

Axial location $\mathrm{x}$

Bulk fluid conditions

Superscripts

a

Air

w Water 



\section{ACKNOWLEDGMENTS}

This report is based on research supported by the Molten Salt Reactor Experiment Remediation Project at Oak Ridge National Laboratory. The assistance of Pamela Byrd, Ken Childs, Lara James, Charlene Patrick, Brad Patton, Mark Wendel, and other contributors who helped make the work possible is greatly appreciated. 


\title{
Thermal Analysis to Support Decommissioning of the Molten Salt Reactor Experiment
}

\author{
Authors \\ C. D. Sulfredge \\ D. G. Morris \\ J. E. Park \\ P. T. Williams
}

\author{
Other Contributors \\ R. N. Borum \\ D. W. Ramey \\ G. L. Yoder
}

\begin{abstract}
As part of the decommissioning process for the Molten Salt Reactor Experiment (MSRE) at Oak Ridge National Laboratory, several thermal-sciences issues were addressed. Apparently a mixture of $\mathrm{UF}_{6}$ and $\mathrm{F}_{2}$ had diffused into the upper portion of one charcoal column in the MSRE auxiliary charcoal bed (ACB), leading to radiative decay heating and possible chemical reaction sources. A proposed interim corrective action was planned to remove the water from the ACB cell to reduce criticality and reactivity concerns and then fill the ACB cell with an inert material. This report describes design of a thermocouple probe to obtain temperature measurements for mapping the uranium deposit, as well as development of steady-state and transient numerical models for the heat transfer inside the charcoal column. Additional numerical modeling was done to support filling of the ACB cell. Results from this work were used to develop procedures for meeting the goals of the MSRE Remediation Project without exceeding appropriate thermal limits.
\end{abstract}

\section{INTRODUCTION}

\subsection{THE MOLTEN SALT REACTOR EXPERIMENT}

The Molten Salt Reactor Experiment (MSRE) was operated at the Oak Ridge National Laboratory (ORNL) from 1965-1969. It utilized fuel based on ${ }^{235} \mathrm{U}$ initially; later a ${ }^{233} \mathrm{U}$ fuel cycle was used. The fuel was in the form of molten fluoride salts. Use of liquid fuel in a continuous flowing system allowed refueling and waste extraction without shutdown of the reactor. Also, the molten salt reactor (MSR) concept promised a high thermal efficiency and, using ${ }^{233} \mathrm{U}$ as a fuel, some fuel generation because of nuclear breeding. Finally, the configuration was inherently safe because a runaway nuclear excursion was not possible; a piping or reactor tank failure would lead to subcritical configurations.

The MSRE was shut down in 1969 due to increasing emphasis on other reactor technologies by the Atomic Energy Commission. The fuel, consisting of lithium, beryllium, and zirconium fluorides as well as $\mathrm{UF}_{4}$, was transferred into drain tanks. Figure 1 shows an elevation view of the MSRE complex. 


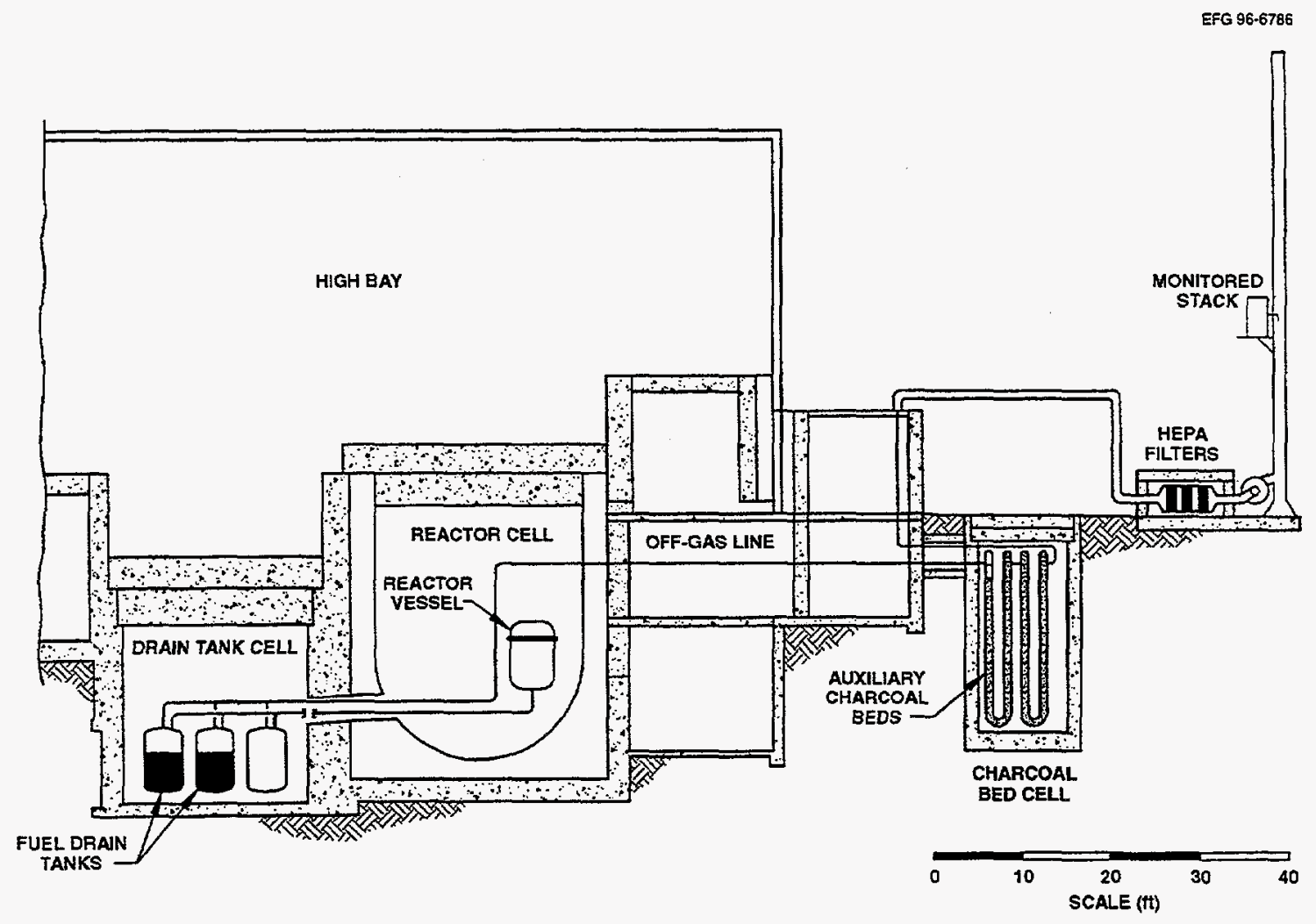

Fig. 1. Elevation view of the MSRE facility.

A charcoal bed system used to scrub off-gassing of various compounds was left in place near the storage tanks. The system consisted of 20 auxiliary charcoal beds (ACBs) fashioned from 6-in.diameter stainless steel 304 (SS304) pipes and located in an underground concrete cell $22.75 \mathrm{ft}$ deep and $10 \mathrm{ft}$ in diameter. The pipes were packed with activated carbon to absorb any off-gases from the holding tanks. To remove heat generated by radioactive decay or any reaction between the carbon and scrubbed gases, the cell was filled with water. The cell was covered by two 18-in.-thick concrete plugs with the top at ground level. A horizontal cross section of the cell is shown in Fig. 2. Figure 3 shows a vertical elevation view.

\subsection{BACKGROUND OF THE MSRE PROBLEM}

Unexpected radiation-induced chemical reactions produced volatile $\mathrm{UF}_{6}$ and $\mathrm{F}_{2}$, which migrated through a failed valve in the piping system connecting the storage tanks to the $A C B$ and allowed a quantity of uranium and accompanying fluorine compounds to enter the top of one of the ACBs. Subsequent measurement of the nuclear radiation field in the ACB cell indicated about $2.6 \mathrm{~kg}$ of uranium was present in the column. ${ }^{1}$

Chemical reactions between the mixture of fluorine, carbon, and metallic salts generate heat. At a sufficiently high temperature, fluorine reacts spontaneously with carbon in a violent fashion. Also, some potential for a reaction between fluorine and the iron in the stainless steel pipe exists if the temperature is sufficiently high. The water surrounding the ACB is valuable as a coolant to maintain the temperature of the bed below the initiation temperature for the carbon-fluorine reaction 


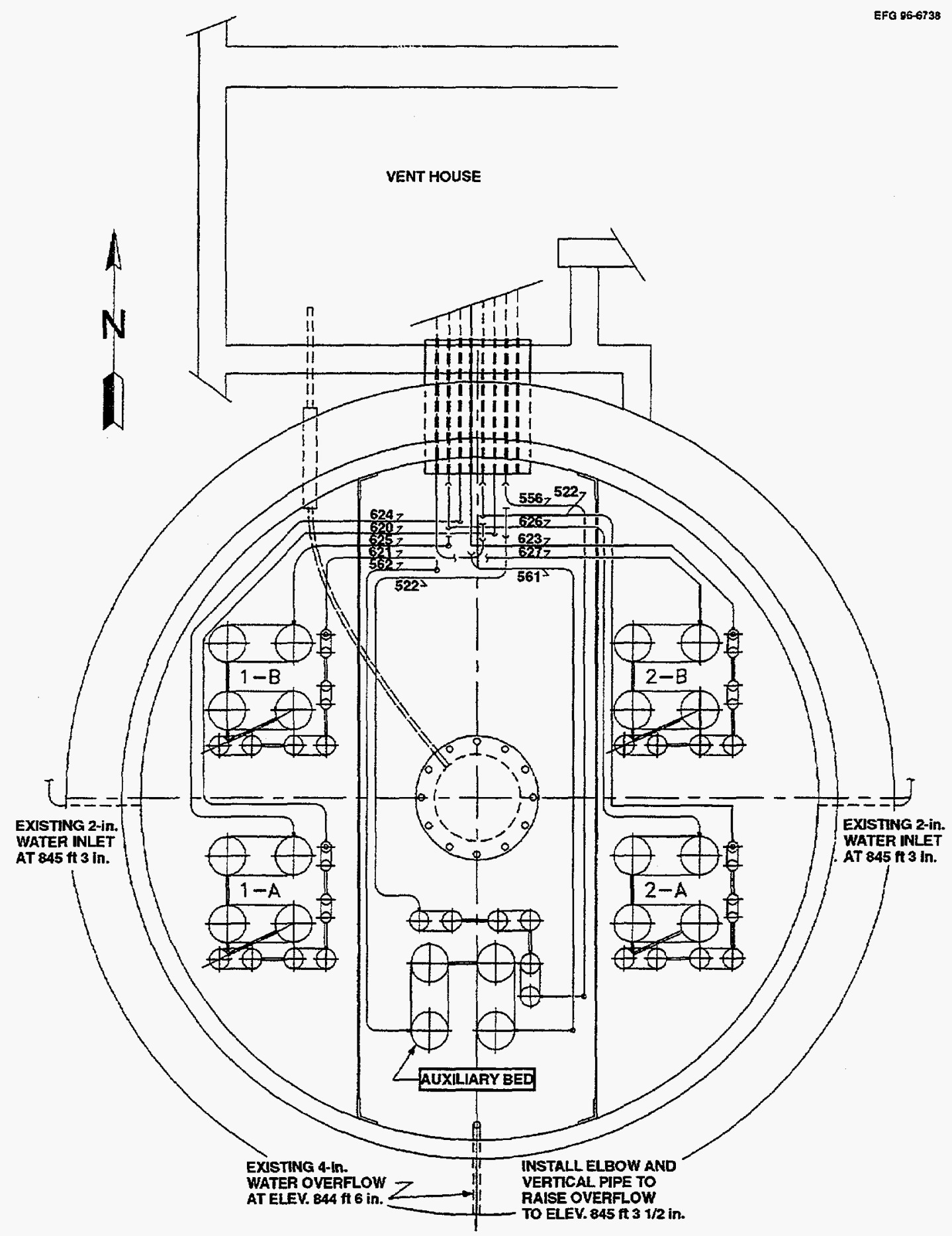

Fig. 2. Cross-section of the MSRE charcoal bed. 


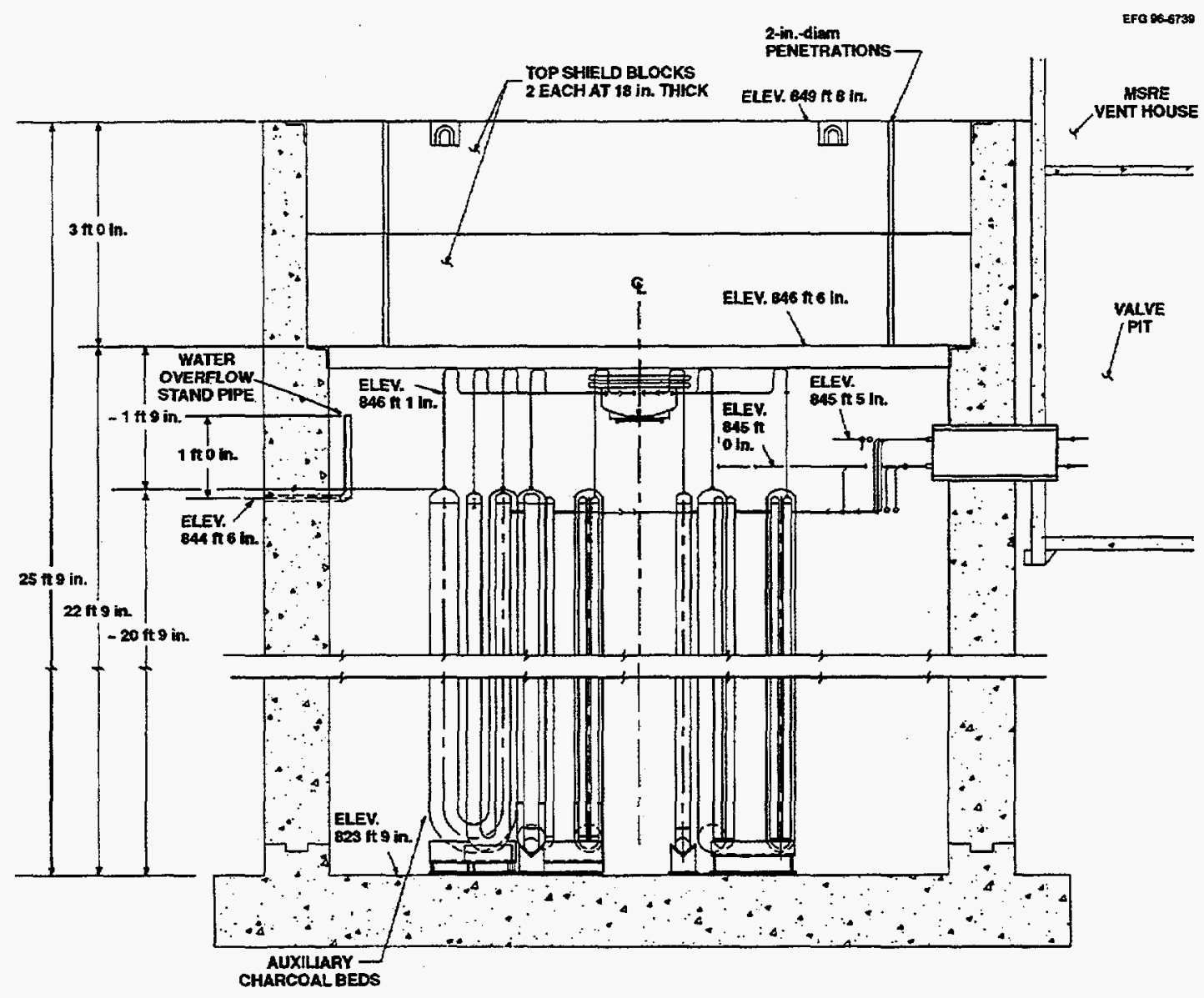

Fig. 3. MSRE charcoal bed elevation view.

and to remove the postfission decay heat from the ACB. At the same time, should any fluorine escape the piping or the $\mathrm{ACB}$, the potential for a reaction between fluorine and water would develop. That reaction is quite violent. Finally, the water surrounding the ACB is a moderator for neutrons. If it leaked into the $\mathrm{ACB}$, the probability of developing a critical configuration would be increased as additional uranium compounds migrate into the carbon bed.

Thus, the presence of water in the ACB cell is definitely a safety concern should the ACB leak. At the same time, the cooling effect of the water reduces the threat of a violent fluorine-carbon or fluorine-iron reaction occurring relative to the situation with air surrounding the pipe.

\subsection{DESCRIPTION OF THE ACB GEOMETRY}

The ACB containing the threatening material is shown in Fig. 4. The spent carbon in the vicinity of the uranium deposit is assumed to have completed any chemical reactions with the $F_{2}$ and $\mathrm{UF}_{6}$. Unspent carbon located below the deposit has not yet undergone any chemical reaction. The charcoal bed filters are constructed from schedule 10 stainless steel pipe $(65 / 8$-in. diam $\times 0.134$-in. wall thickness) $\sim 20 \mathrm{ft}$ long. The pipe is topped with a cap welded to the pipe. The pipe is packed with graphite to within 4.5-in. of the top of the cap. A 2.5 -in. layer of stainless steel wool (or mesh) 


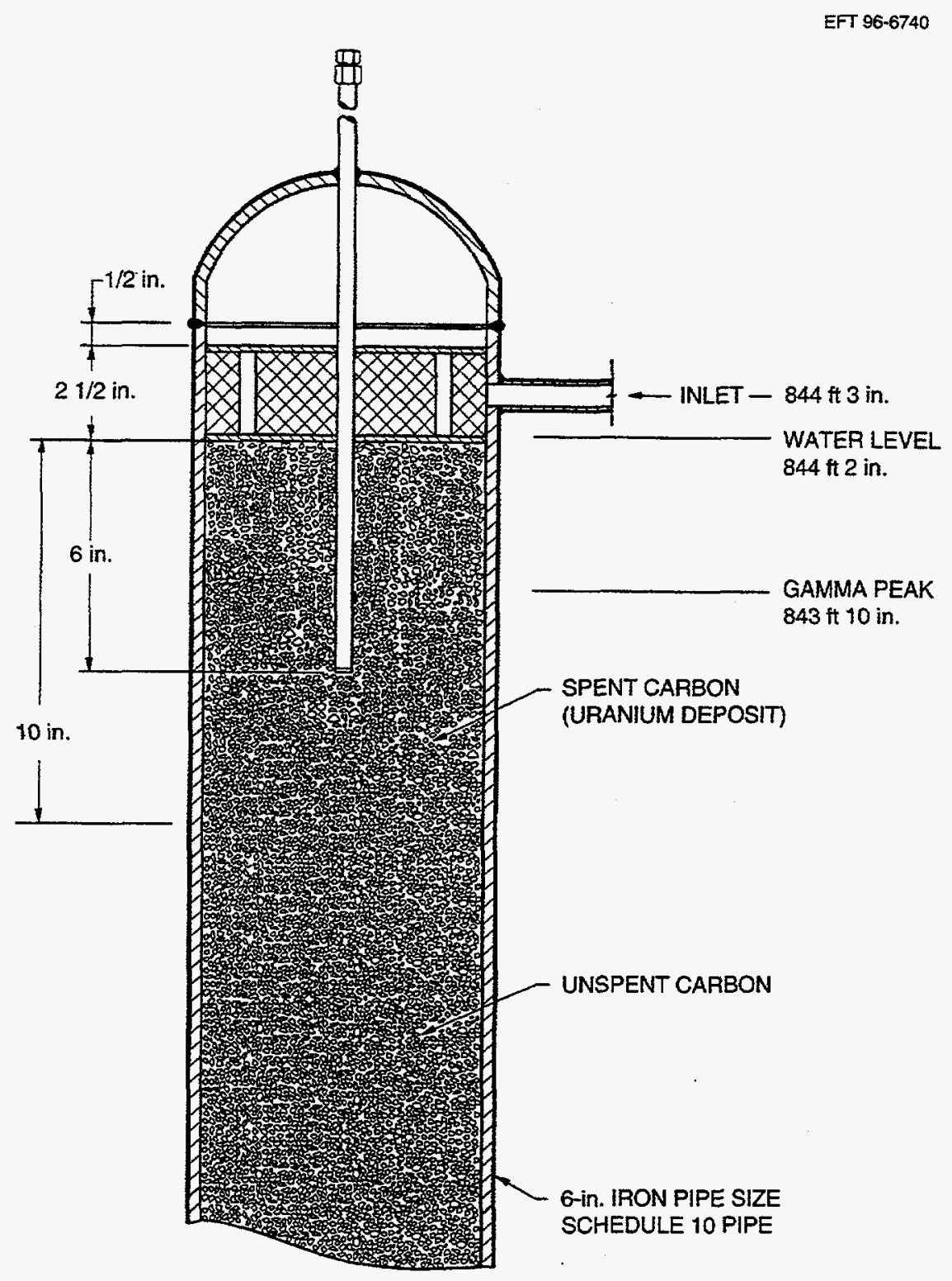

Fig. 4. Schematic of the charcoal column contaminated with uranium.

lies immediately above the graphite, while the top 2 in. within the cap is empty. A thermocouple well extends $\sim 19$ in. above the top of the cap and to a depth of $\sim 10.5$ in. below the top of the cap, 6 in. into the interior of the ACB. A 1/8-in. type K sheathed thermocouple is installed at the bottom of the thermowell. The inner and outer diameters of the thermowell are 0.269 and 0.405 in., respectively. The thermowell assembly in the contaminated column is designated ACB1-1 to distinguish it from the thermocouples mounted in other columns of the charcoal bed. 


\subsection{OBJECTIVE}

Overall, as stated in Ref. 1, the MSRE Remediation Project objective is to put the MSRE "in acceptable condition for long-term surveillance and maintenance." To support that goal, the remainder of this report describes a number of model studies and experiments designed to determine the changes in ACB temperature that might occur if the water in the cell were partly or completely drained. The information presented here was used by the MSRE Remediation Project to assess the thermal implications of interim corrective measures proposed for the ACBs. 


\section{PRELIMINARY MODEL STUDIES}

\subsection{INTRODUCTION}

At the time this study was initiated, very little thermal and radiation data in or around the ACB described in Chapter 1 were available. Temperature measurements were obtained from the thermocouple located within the ACB, but the reliability, accuracy, and quality of the thermal contact within the ACB were not known. Surveys of temperature vs depth and radiation level vs depth were performed periodically, as illustrated by Fig. 5, which records the thermal and radiation profiles after the water was removed from the charcoal bed. Finally, temperatures were available from other locations within the cell containing the ACBs .

During the course of this study (July 1994 to April 1995), fundamental information was being located or developed regarding the potential chemical reactions involving fluorine and the other materials in the ACB. The objective was to identify the most hazardous reactions and, if possible, to define a "safe temperature" below which these reactions would not occur. Thermophysical properties for the activated charcoal packing material in the ACB were not well documented. The location of reaction products within the ACB was defined only approximately by the vertical surveys of temperature and radiation levels. Scientists and engineers who had worked on the MSRE contributed their knowledge of the as-built specifications of the cell containing the ACBs and the ACBs themselves. All of this information, reported elsewhere, was used to enhance or modify the thrust of the investigation reported here. However, during the time these preliminary studies were done, much of the information described in this paragraph was simply not available.

As fundamental information about the contaminated system was being developed, the preliminary model studies exploited the readings from thermocouple ACB1-1 to identify the sensitivity of the maximum temperature predicted by the model to changes in various unknown quantities needed for the model.

In this section, a fundamental thermal model of the ACB assembly is presented, and several sensitivity studies and their results are described. HEATING 7.2 (Ref. 2), a thermal analysis code developed at ORNL, was used for this work.

\subsection{PRELIMINARY MODEL OF ACB ASSEMBLY}

\subsubsection{Overview}

A model of the carbon-packed pipe was constructed for the finite difference thermal analyzer, HEATING 7.2. The model described an axisymmetric problem with adiabatic surfaces at the ends of the cylindrical region; heat transfer coefficients for natural convection to water or air were specified over the appropriate portions of the surface of the cylinder. Figure 6(a) shows the regions and boundary conditions of a typical HEATING 7.2 model used in this stage of the analysis, and the corresponding input file is presented in Fig. 6(b).

\subsubsection{Material Regions}

The SS304 pipe was filled with four zones of material that were stacked axially. The bottom zone was carbon without heat generation due to radioactive decay or chemical reaction. The thickness of this unaffected zone was initially taken to be $1.5 \mathrm{ft}$. Just above the unaffected zone was a shallow (assumed to be $1 \mathrm{in}$. thick) disk of carbon-uranium-fluorine components in which decay heating and 


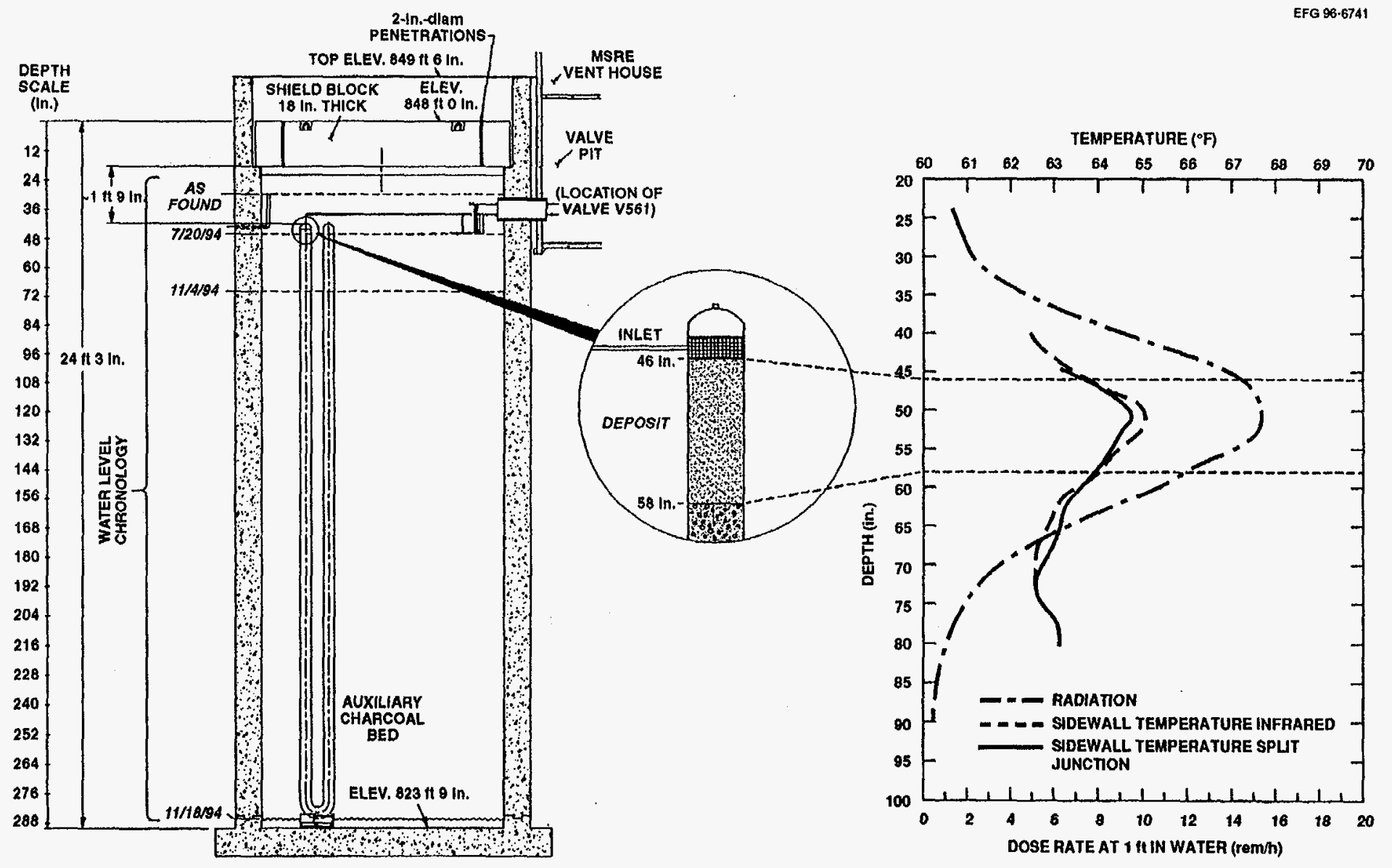

Fig. 5. Temperature and radiation surveys of the MSRE charcoal bed. 


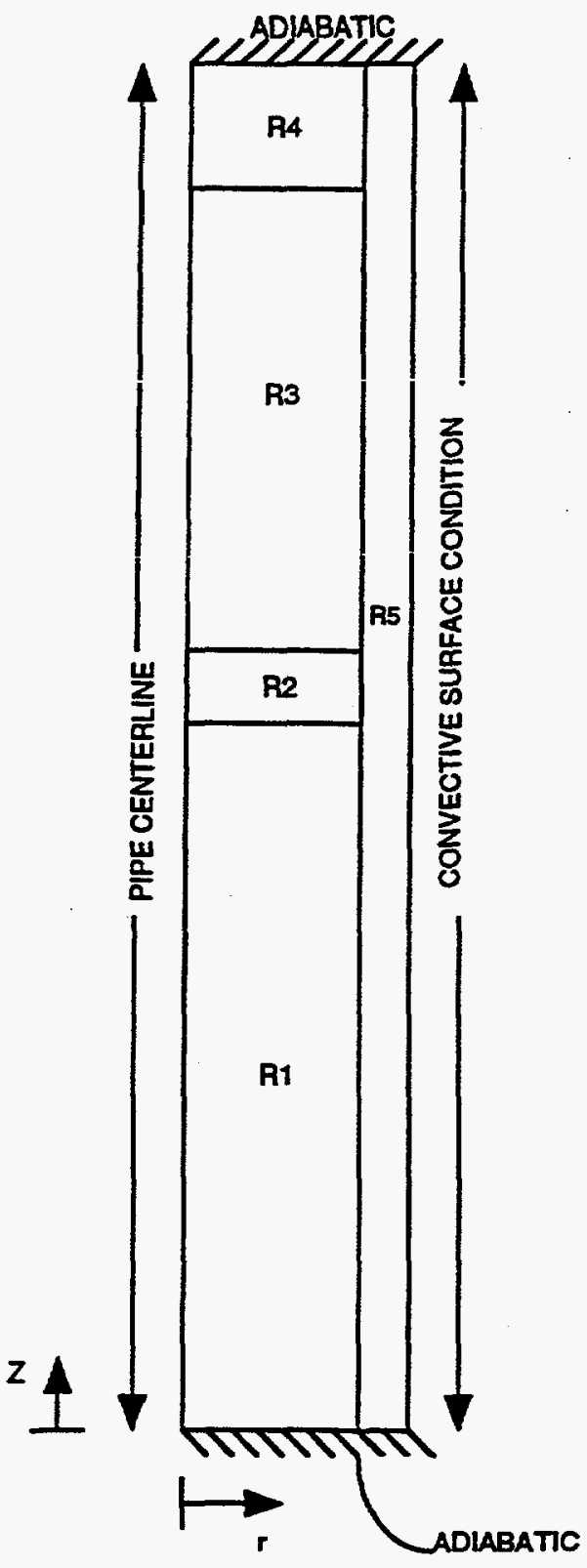

Molter Salt - Water cooled, $k=0.25$

- A vertical pipe packed with graphite is surrounded by water.

- Over a period of time, some combination of uranium, fluorine,

* and graphite has reacted (inhomogereously), creating heat

- generation due to the chemical reactions and additional heat

* from radioactive decay. The distribution of these heat

- sources is not known, so some plausible alternatives will

* be tested.

- The intent is to remove the water from outside the pipe,

- lessening the nuclear criticality problem but making the

* heat removal problem more difficult, because the heat

- previously removed by natural convection of water must

- now be removed by natural convection of air.

- "Customary Units" - BTU, F, FT, HR, LBm

50030

REGIONS

* carbon bed below contaminants = mat1. 4

$\begin{array}{llllllll}1 & 1 & 0.0 & 0.2649 & 0.0 & 0.0 & 0.0 & 1.5\end{array}$

1000000010

* carbon containing chemical reactions = matl. 1

$\begin{array}{llllllll}2 & 1 & 0.0 & 0.2649 & 0.0 & 0.0 & 1.5 & 1.5833\end{array}$

1200000000

* carbon containing decay heat = mat 1.1

$\begin{array}{llllllll}3 & 1 & 0.0 & 0.2649 & 0.0 & 0.0 & 1.5833 & 2.4167\end{array}$

11

* steel mesh above the carbon bed = mat 1.2

$\begin{array}{llllllll}4 & 2 & 0.0 & 0.2649 & 0.0 & 0.0 & 2.41672 .6250\end{array}$

$\begin{array}{llllllll}1 & 0 & 0 & 0 & 0 & 0 & 0 & 1\end{array}$

- steel pipe outside the bed materials = mat1. 3

$\begin{array}{llllllll}5 & 3 & 0.2649 & 0.2760 & 0.0 & 0.0 & 0.0 & 2.6250\end{array}$

$\begin{array}{lllllllll}1 & 0 & 0 & 2 & 0 & 0 & 1 & 1\end{array}$

BOUNDARY

1176.0

$\begin{array}{lllllll}1.0 \mathrm{e}-6 & 0.0 & 0.0 & 0.0 & 0.0 & 0\end{array}$

2176.0

$\begin{array}{llllllllll}30.0 & 0.0 & 0.0 & 0.0 & 0.0 & 0\end{array}$

MATERIALS

carbon $0.25 \quad 33.072 \quad 0.17$

2 steelwol $0.62 \quad 5.0 \quad 0.001$

$3 * 31333$

4 carbon $0.25 \quad 33.0720 .17$

INITIAL

184.0

HEAT

142.209

$2 \quad 4357.8$

XGRID

$\begin{array}{lll}0.0 & 0.2649 & 0.2760\end{array}$

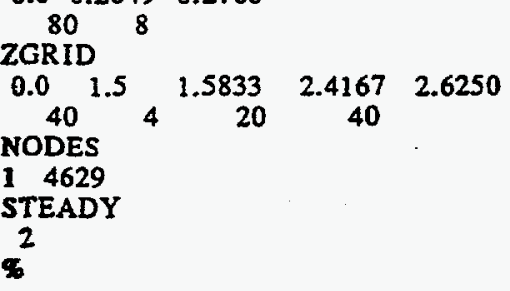

(b)

Charcoal with decay heat

Stainiess steel wool

Stainless steel pipe wall

(a)

Fig. 6. (a) Schematic of a typical HEATING7.2 model and thermal boundary conditions and (b) Sample HEATING7.2 input file. 
chemical heating were specified. Next was a plug of the same material (10 in. thick) in which the chemical reaction has ceased but the decay heating continued. Finally, at the top of the column, a plug of steel mesh ( 2.5 in. thick) of very low thermal conductivity completed the model. The thermowell extended through the steel mesh and 6 in. into the 10-in.-thick plug from above.

\subsubsection{Thermal Transport Properties}

The thermal transport properties of SS304, taken from the HEATING 7.2 library (material number 3133), were treated as temperature dependent. The properties of the contaminated graphite materials and the steel mesh were not known. These were estimated based on assumptions about the composition of the materials.

\subsubsection{Numerical Technique}

The system of unknown temperatures was solved directly using Gaussian elimination. A preliminary problem was solved using three finite difference meshes: $(89 \times 105) 9345$ nodes, $(23 \times$ 28) 644 nodes, and $(53 \times 45) 2385$ nodes. A plot of the centerline temperature calculated using each of these discretizations (Fig. 7) showed that peak temperature determined using the coarse mesh was within $1^{\circ} \mathrm{F}$ of that calculated using the refined meshes. The solutions from the two high-density meshes were virtually identical. Using an IBM system/6000-320 workstation, a minute or less was required to obtain the steady-state temperature distribution throughout the modeled portion of the ACB.

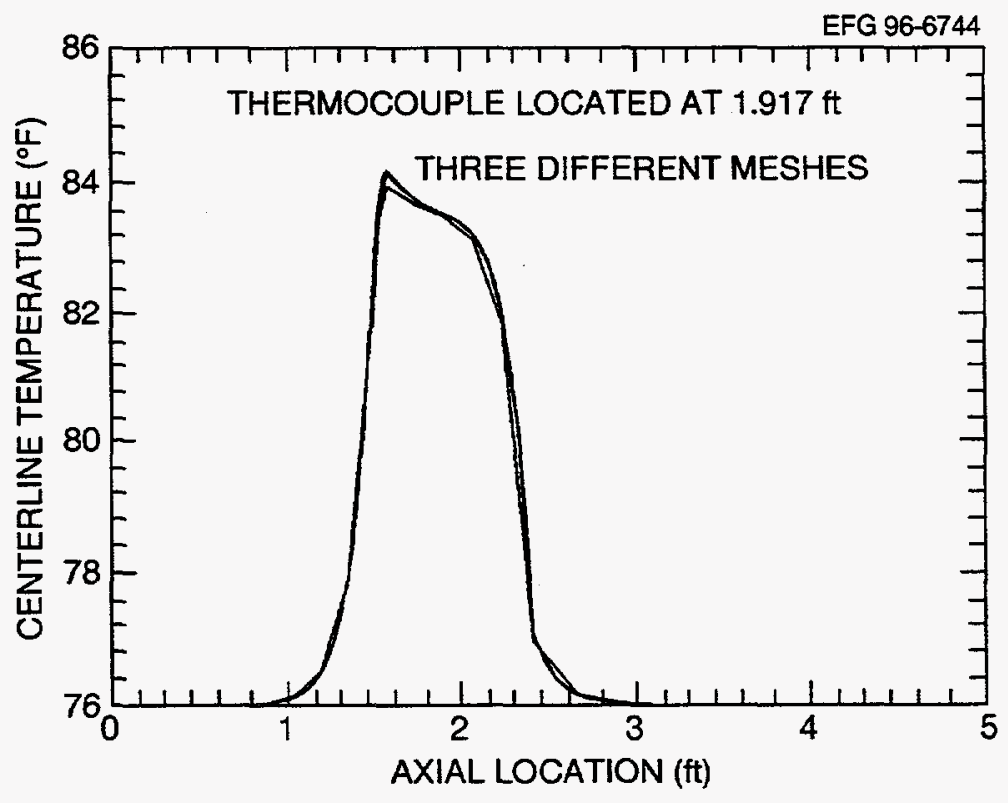

Fig. 7. Bed centerline temperature for various mesh discretizations. 


\subsubsection{Solution Strategy}

For most of the preliminary studies, the temperature recorded by the thermowell thermocouple was assumed to be accurate. That temperature was assigned to a point on the centerline of the ACB at a depth of 6 in. into the ACB filler material. In the various studies summarized below, one or more of the unknown parameters in the model was varied systematically until the calculated thermowell temperature matched the assumed value. For most of these studies, the desired information was the value and location of the maximum temperature within the $A C B$. To estimate the effect of draining the ACB cell, companion cases were also run in which unknown model parameters were manipulated to match the observed thermocouple temperatures with water cooling. The model parameters were then held fixed, and the maximum temperature that would be obtained with air cooling was calculated.

\subsection{PRELIMINARY MSRE ACB 2-D THERMAL ANALYSIS RESULTS}

Results from four primary cases are presented. The cases were designed to account for some of the uncertainties in heat source location and strength and uncertainties in physical properties. For these cases, the natural-convection coefficients used were $\mathrm{h}=30 \mathrm{Btu} / \mathrm{h}-\mathrm{ft}^{2}{ }^{\circ}{ }^{\circ} \mathrm{F}$ for water on the outside of the pipe and $\mathrm{h}=1 \mathrm{Btu} / \mathrm{h}-\mathrm{ft}^{2}-{ }^{\circ} \mathrm{F}$ for air on the outside of the pipe. Total decay heating was assumed to be $2.5 \mathrm{~W}$, distributed uniformly over a portion of the carbon matrix, as suggested by surveys of the radiation emitting from the $\mathrm{ACB}$, as documented in Fig. 5. Thermal conductivity for the various portions of the carbon bed was assigned values from 0.1 to $0.5 \mathrm{Btu} / \mathrm{h}-\mathrm{ft}-{ }^{\circ} \mathrm{F}$, spanning the range of data obtained from the literature. ${ }^{3-5}$ The results are summarized in Table 1.

Cases A, C, E, and $\mathrm{G}$ analyzed the impact of two different distributions of the $2.5 \mathrm{~W}$ of decay heating and several values of the thermal conductivity of the carbon when the ACB was surrounded with water. For each of these cases, the total heating due to chemical reaction was varied systematically until the temperature calculated at the thermocouple location matched the recorded value for the thermocouple, $84^{\circ} \mathrm{F}$. The bulk water temperature was assumed to be $76^{\circ} \mathrm{F}$. The companion cases, $\mathrm{B}$, $\mathrm{D}, \mathrm{F}$, and $\mathrm{H}$, maintained the heat source required with water cooling but switched to air cooling. For each case, the maximum temperature on the inner surface of the pipe and the maximum temperature at the centerline of the ACB are recorded. The pipe wall temperature is important because of possible fluorine-iron reactions; the centerline temperature is of concern because of possible reactions between fluorine, uranium, and carbon.

The case pairs A-B and C-D indicate the effect of increasing the thermal conductivity of the carbon. If the conductivity of the carbon in the ACB is higher than expected, the heating due to chemical reactions must be greater to maintain the thermocouple temperature at $84^{\circ} \mathrm{F}$. As a result, more heat must be removed overall, and the maximum centerline and pipe wall temperatures are higher than in the base case (A). The increased temperature difference required to remove the heat by convection to air gives rise to much higher centerline and pipe wall temperatures after removal of the water.

Examining the results of case pair E-F, in which the conductivity of the carbon below the chemical reaction is reduced to $0.25 \mathrm{Btu} / \mathrm{h}-\mathrm{ft}-{ }^{\circ} \mathrm{F}$, the maximum centerline and pipe wall temperatures are not reduced substantially. This indicates that the carbon below the reaction and decay heat zones is not an important path for removal of the heat. 
Table 1. Summary of preliminary ACB 2-D thermal analysis results

\begin{tabular}{|l|c|c|c|c|c|c|}
\hline \multicolumn{1}{|c|}{ Water temperature $=76^{\circ} \mathrm{F}$} & $\begin{array}{c}\mathrm{k} \text { for } \mathrm{C} \\
\text { below } \\
\text { reaction } \\
\text { zone }\end{array}$ & $\begin{array}{c}\mathrm{k} \text { for } \mathrm{C} \text { in } \\
\text { and above } \\
\text { reaction } \\
\text { zone }\end{array}$ & $\begin{array}{c}\text { Chemical } \\
\text { heating } \\
(\mathrm{W})\end{array}$ & $\begin{array}{c}\text { Decay } \\
\text { heating } \\
(\mathrm{W})\end{array}$ & $\begin{array}{c}\text { Peak C/L } \\
\text { temperature } \\
\left({ }^{\circ} \mathrm{F}\right)\end{array}$ & $\begin{array}{c}\text { Peak } \\
\text { temperature, } \\
\text { inner pipe wall } \\
\left({ }^{\circ} \mathrm{F}\right)\end{array}$ \\
\hline $\begin{array}{l}\text { Case A: Water cooled, decay } \\
\text { heat in and above reaction } \\
\text { zone }\end{array}$ & 0.1 & 0.1 & 1.20 & 2.5 & 92.35 & 76.20 \\
\hline $\begin{array}{l}\text { Case B: A with air cooling, } \\
\text { decay heat in and above } \\
\text { reaction zone }\end{array}$ & 0.1 & 0.1 & 1.20 & 2.5 & 97.16 & 81.83 \\
\hline $\begin{array}{l}\text { Case C: Water cooled, decay } \\
\text { heat in and above reaction } \\
\text { zone }\end{array}$ & 0.5 & 0.5 & 51.81 & 2.5 & 180.92 & 87.88 \\
\hline $\begin{array}{l}\text { Case D: C with air cooling, } \\
\text { decay heat in and above } \\
\text { reaction zone }\end{array}$ & 0.5 & 0.5 & 51.81 & 2.5 & 265.88 & 186.72 \\
\hline $\begin{array}{l}\text { Case E: Water cooled, decay } \\
\text { heat in and above reaction } \\
\text { zone }\end{array}$ & 0.25 & 0.5 & 45.20 & 2.5 & 186.42 & 87.18 \\
\hline $\begin{array}{l}\text { Case F: E with air cooling, } \\
\text { decay heat in and above } \\
\text { reaction zone }\end{array}$ & 0.25 & 0.5 & 45.20 & 2.5 & 265.26 & 178.25 \\
\hline $\begin{array}{l}\text { Case G: Water cooled, decay } \\
\text { heat above reaction zone }\end{array}$ & 0.1 & 0.1 & -0.049 & 2.5 & 84.04 & 76.19 \\
\hline $\begin{array}{l}\text { Case H: G with air cooling, } \\
\text { decay heat above reaction } \\
\text { zone }\end{array}$ & 0.1 & 0.1 & -0.049 & 2.5 & 87.55 & 80.00 \\
\hline
\end{tabular}

For the case pair $\mathrm{G}-\mathrm{H}$, the decay heat is deposited only above the reaction zone (top $10 \mathrm{in}$. of the carbon bed). With this slight additional concentration of decay heating, some heat removal from the reaction zone is required to match the model prediction of the temperature at the thermocouple with the observed temperature.

\subsection{UPDATE ON MSRE ACB PRELIMINARY THERMAL ANALYSIS}

For this analysis, a more detailed HEATING 7.2 model was used. This model included the thermowell structure and corrected some minor discrepancies in the previous model. The major conclusions of the study follow:

1. Introducing a variable heat transfer coefficient over the pipe surface leads to slightly higher aircooling temperatures than the constant coefficient cases. 
2. The uncertainty in reaction zone thickness does not seem to be a serious concern. Reducing the assumed thickness of the reaction zone from 1 in. to $0.5 \mathrm{in} ., 0.25 \mathrm{in}$., or $0.03 \mathrm{in}$. increases the maximum water-cooling temperatures on the inner surface of the stainless steel pipe by no more than $5.86^{\circ} \mathrm{F}$, and the corresponding air-cooling temperature changes were less than $51.3^{\circ} \mathrm{F}$.

3. Moving the assumed location of the chemical reaction plane further down below the thermocouple leads to a drastic increase in the maximum temperatures observed. A 2-in. displacement corresponds to a maximum stainless steel temperature of $525.44^{\circ} \mathrm{F}$, while a 4-in. shift yields $1593.2^{\circ} \mathrm{F}$ under air cooling. Apparently the reaction location must be known precisely to obtain a meaningful boundary on the temperatures that might be encountered.

4. A table was compiled showing the expected temperature difference between the convective surface and the pool water under each set of conditions. Appreciable differences were only observed for the lower reaction zone cases. However, a convective temperature drop of at least $5^{\circ} \mathrm{F}$ was always present in cases that would lead to high temperatures for air cooling.

5. The ACB thermowell has been incorporated in the computer model and its impact assessed in a few initial calculations. It was found to have a significant effect on results; however, compared to other uncertainties, its effect is of lesser concern.

\subsection{THERMAL CONDUCTIVITY OF STEEL MESH}

The conductivity used for the steel mesh above the carbon column in the ACB was varied between 0.01 and 0.10 of that used for the stainless steel pipe wall of the ACB with a constant value for the decay heating $(2.5 \mathrm{~W})$. The temperature forecast for the centerline thermocouple location changed $<0.25^{\circ} \mathrm{F}$. Therefore, the uncertainty in the mesh conductivity is probably not a major concern.

\subsection{USING MEASURED WATER TEMPERATURES AS BOUNDARY CONDITIONS}

Periodically, the temperature of the water in the ACB cell was measured vs depth. Using the default model assumptions except for the water boundary conditions, a series of cases was run with the measured temperature profile instead of the constant value of $76^{\circ} \mathrm{F}$ as a boundary condition. Higher temperatures were calculated for the ACB centerline and for the inner wall of the steel pipe, indicating a greater overall system thermal resistance. Use of the measured temperatures was recommended for any additional studies.

\subsection{CONCLUSIONS}

As a result of the studies summarized in this section, it was concluded that the information from the single thermocouple within the ACB was not adequate to build HEATING models capable of assessing the relative risks of draining the water from the cell vs taking no action. Design, calibration, and application of a split junction thermocouple traversing probe to obtain additional temperature data is described in subsequent chapters. 



\section{DEVELOPMENT AND TESTING OF THERMOCOUPLE PROBE FOR ACB TEMPERATURE MEASUREMENTS}

Because of uncertainties in the heat source strength and distribution and in the bed thermal conductivity, it was necessary to collect sufficient temperature data to characterize the system thermally prior to draining water from the $A C B$ cell. Temperature data were obtained from the thermocouple (ACB 1-1) located in the top of the column where the uranium was deposited. In addition, ACB cell air and water bulk temperatures were obtained. Unfortunately, these data were not sufficient to model the system adequately. Given that it was not possible to obtain internal ACB temperatures at any additional axial locations, it was decided that temperatures would be measured along the length of the column surface. These temperatures, along with bulk water (or air) temperature measurements, would allow a calculation to be made of the heat flow from the column. To determine the column surface and bulk fluid (water or air) temperatures, a thermocouple probe was developed.

Based on ACB analysis using the HEATING7 computer code, it was determined that a column surface-to-water temperature difference of just a few degrees Fahrenheit could indicate a potential temperature problem after draining the water from the ACB cell. Although absolute temperature measurements with Type $\mathrm{K}$ thermocouples like those used in the probe are only accurate to within $\sim 2^{\circ} \mathrm{F}$, the quantity of interest here is the temperature difference. By establishing any initial thermocouple bias under isothermal conditions, temperature differences accurate to within tenths of a degree Fahrenheit can be measured. As discussed below, there were other concerns (beyond thermocouple accuracy itself) about whether the probe would provide a "true" measurement of the column surface temperature. Therefore, probe experimental testing was performed in a mock-up of the ACB column and cooling environment; these tests and the design of the probe are discussed in this section.

\subsection{PROBE DESIGN}

Given the significant radiation field near the top of column, it was necessary to develop a thermocouple probe that could be lowered into the ACB cell through a hole in the shield blocks. D. W. Ramey and R. N. Borum of the Chemical Technology Division led the design of such a probe, which utilized a split junction thermocouple to measure the column surface temperature. A standard thermocouple was used to measure the bulk fluid temperature. After the probe tests discussed here were performed, an infrared thermometer (for measuring column surface temperature in air only) was installed on the probe prior to performing the ACB temperature measurements. The lower end of the probe is pictured in Fig. 8. "Suction cups" are positioned on the probe pins of the split junction thermocouple and, as discussed in the next section, were added during probe testing to provide more accurate column surface temperature measurements. The application of the probe at the MSRE is shown in Fig. 9. In the monitor, the lower portion of the probe is shown positioned against the column to obtain temperature measurements under water. The pole pictured is $\sim 10 \mathrm{ft}$. long. A split junction thermocouple was used so that it would be known that the column surface temperature was being measured. That is, until good contact is made between the split junctions and the column surface, no temperature reading can be obtained.

The bulk fluid temperature thermocouple was placed so that it would be 4 in. from the column surface and at the same elevation as the split junction thermocouple. The 4-in. distance from the column surface was chosen to ensure the thermocouple would be outside of the thermal boundary layer so that the true free-steam (bulk) fluid temperature was measured. Conservative calculations of the boundary layer thickness (that is, calculations that provide the maximum possible thickness) were 


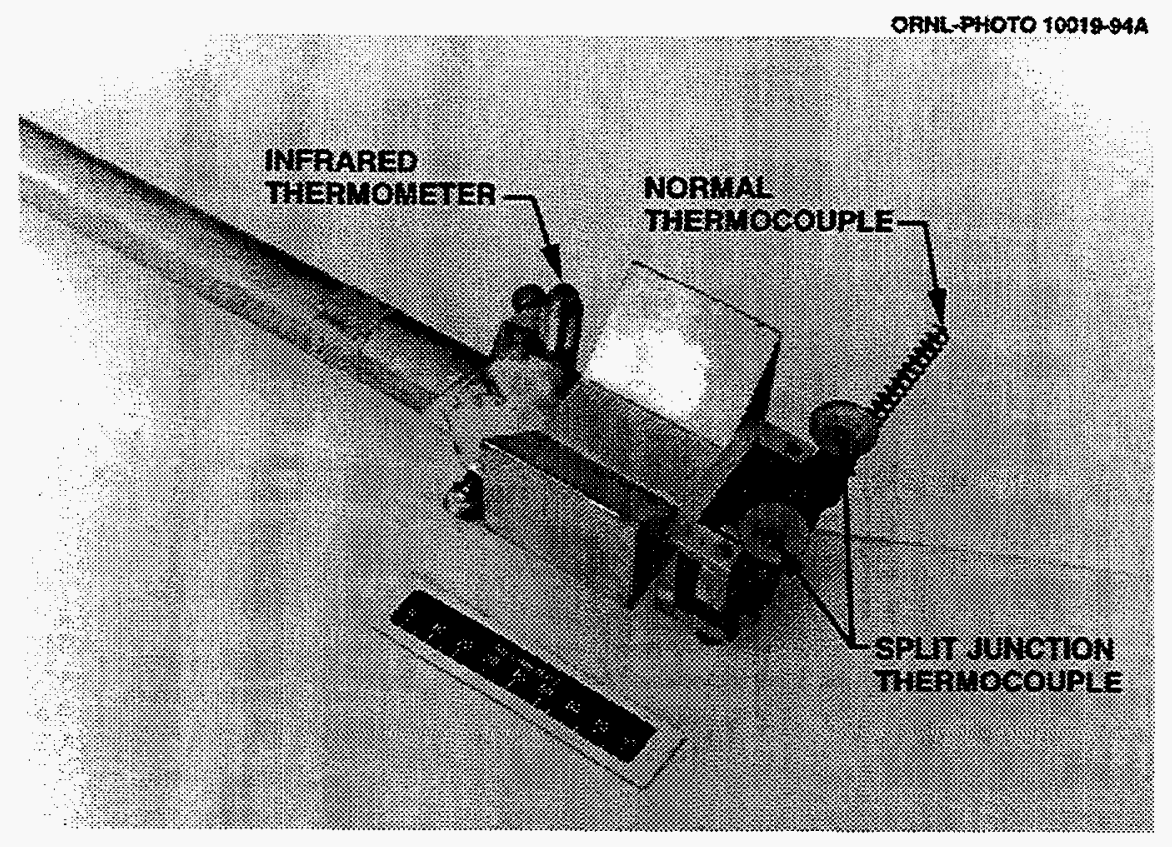

Fig. 8. Lower portion of thermocouple probe.

performed for air and water under laminar and turbulent conditions. Laminar boundary layer calculations were made using results given by Schlichting ${ }^{6}$ and by Incropera and DeWitt ${ }^{7}$. Results in both references are provided in plotted form, showing the temperature profile in the thermal boundary layer as a function of the parameter $\eta$, defined as:

$$
\eta=\frac{y}{x}\left(\frac{G r_{x}}{4}\right)^{1 / 4}
$$

where

$$
\begin{aligned}
y & =\text { perpendicular distance from vertical wall, } \\
x & =\text { distance along vertical wall, } \\
G r_{x} \text { (Grashof number) } & =\frac{g \beta\left(T_{s}-T_{\infty}\right) x^{3}}{v^{2}} \\
g & =\text { gravitational acceleration, } \\
\beta & =\text { thermal expansion coefficient, } \\
T_{s} & =\text { wall surface temperature, } \\
T_{\infty} & =\text { bulk fluid temperature, } \\
v & =\text { kinematic viscosity. }
\end{aligned}
$$




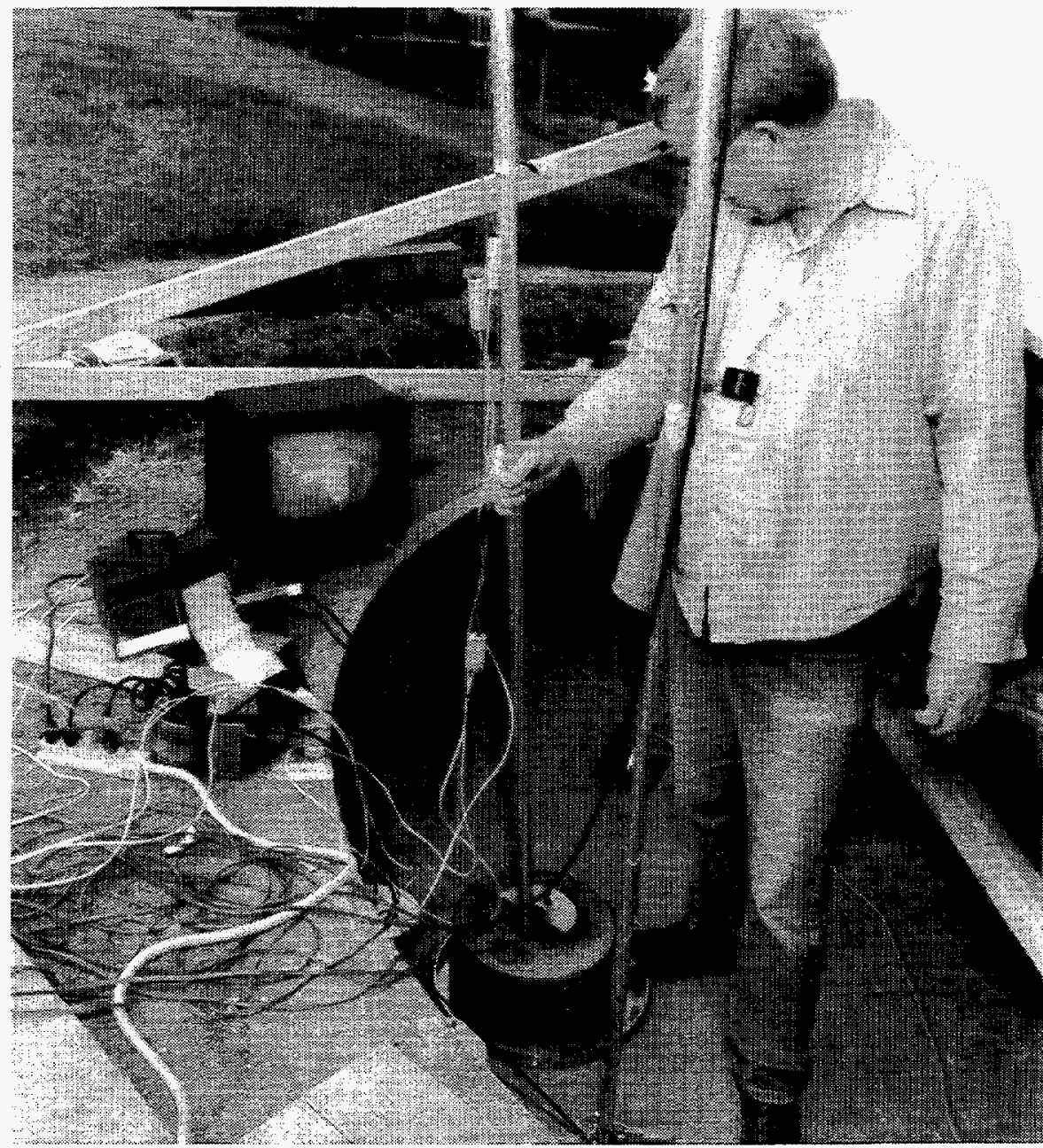

Fig. 9. Application of thermocouple probe at the MSRE. Monitor shows lower portion of probe against column under water.

To define the thermal boundary layer thickness, $\delta_{x}$, $\eta$ was set equal to 4 , so that at least $95 \%$ of the convective temperature difference $\left(T_{s}-T_{\infty}\right)$ will occur within a distance $y=\delta_{x}$ of the wall, whether the fluid is water or air. It can be seen from Eq. (1) that $y=\delta_{x}$ increases with increasing $x$ and decreasing $\left(T_{s}-T_{\infty}\right)$. Therefore, the largest thermal boundary layer thickness that could be encountered will be associated with the maximum possible heated length and the minimum temperature difference expected in the ACB. For both water and air calculations, $x$ was taken to be $L=2.625 \mathrm{ft}$, the full heated height expected for the ACB column. For water, the lower bounding value of $\left(T_{s}-T_{\infty}\right)$ was taken to be $0.1^{\circ} \mathrm{F}$, while for air a value of $5^{\circ} \mathrm{F}$ was chosen as the smallest wall temperature difference that could lead to significant boundary layer formation or indicate thermal problems in the ACB. Using these values, along with a $T_{\infty}$ of $76^{\circ} \mathrm{F}, \delta_{L}{ }^{w}$ (water) and $\delta_{L}{ }^{a}$ (air) were calculated to be

$$
\begin{aligned}
& \delta_{L}^{w}=1.93 \mathrm{in.}, \\
& \delta_{L}{ }^{a}=1.50 \mathrm{in} .
\end{aligned}
$$


Turbulent boundary layer calculations were made using the following equation given in Rohsenow and Choi: ${ }^{8}$

$$
\frac{\delta}{x}=0.565 G r_{x}^{-0.1} \operatorname{Pr}^{-8 / 15}\left[1+0.494 \operatorname{Pr}^{2 / 3}\right]^{0.1}
$$

where

$\delta=$ boundary layer thickness (with the velocity and temperature layer thickness assumed equal),

$\operatorname{Pr}=$ Prandtl number,

$G r_{x}$ and $x$ are as defined previously.

By examining Eq. (2), it can be seen that $\delta$ increases with increasing $x$ and with decreasing $G r_{x}$. To have a turbulent flow $R a_{x}$ (Rayleigh number) $=G r_{x} P r$ must be $>10^{9}$, so the maximum thermal boundary layer thickness obtainable from Eq. (2) occurs at the transition to turbulence, with $G r_{x}=$ $10^{9} / \mathrm{Pr}$. This result, along with $P r=6.42$ (water) and 0.709 (air) at $T_{\infty}=76^{\circ} \mathrm{F}$ gives for $G r_{x}{ }^{w}$ (water) and $G r_{x}^{a}$ (air):

$$
G r_{x}^{w}=1.56 \times 10^{8}
$$

and

$$
G r_{x}^{a}=1.41 \times 10^{9}
$$

Using these values and $x=L=2.625 \mathrm{ft}$ in Eq. (2) yields for $\delta_{L}{ }^{w}$ (water) and $\delta_{L}{ }^{a}$ (air):

$$
\delta_{L}^{w}=1.106 \text { in., }
$$

and

$$
\delta_{L}^{a}=2.69 \mathrm{in}
$$

Hence, it follows that a 4-in. separation between the column surface and the bulk fluid thermocouple will place the thermocouple in the free steam regardless of whether the natural circulation flow is laminar or turbulent.

Several aspects of the probe design were of concern regarding its functionality in measuring the wall surface temperature.

1. The effect of the aluminum "V-block" on natural-convection flow along the column and columnto-V-block heat conduction.

2. Conduction/convection heat transfer along the split junction pins that contact the column. 
3. Does the split junction thermocouple provide a true measurement of the column surface temperature or is it significantly influenced by the lower fluid temperatures in the adjacent thermal boundary layer?

An analytical assessment of these concerns would require significant effort (e.g., for item 1, a multidimensional conduction/convection calculation involving contact resistances would be required). On the other hand, experimental testing of the probe in a small mock-up facility would require less effort and be more reliable. This approach was chosen to verify the probe and is described in the following section.

\subsection{PROBE TESTING}

Testing of the thermocouple probe was performed in a mock-up facility that closely simulated the configuration of the ACB column. A schematic diagram of the mock-up is provided in Fig. 10. A section of piping identical to that in the charcoal bed was placed in an open tank containing water. The inside of the pipe, which was sealed at the bottom, also contained water that was circulated through a constant-temperature bath manufactured by the NESLAB company. The temperature of the bath was controlled so that it was a few degrees Fahrenheit warmer than the water outside the pipe, thereby providing a heat source on the inside of the pipe. Thermocouples were taped on the inside and outside surface of the pipe, and one was "pinged" into the wall of the pipe and located at about the midpoint of the wall thickness. Because of concerns about their contact with the wall, the data from the thermocouples taped to the wall were only used qualitatively. The probe was suspended from $\sim 8 \mathrm{ft}$ above the pipe/tank assembly through a hole in an overhead scaffold. This set-up simulates the situation present at the MSRE, where the probe must be lowered through a hole in the shield blocks to measure ACB column and fluid temperatures as shown in Fig. 9. During testing, the probe was often positioned against the pipe wall by hand from below the platform and secured with clamps. Although different from actual operating conditions, this technique expedited the testing process.

Testing was also performed using a light bulb heat source $(300 \mathrm{~W})$ in place of the water bath heat source. The first set of tests was performed in this configuration and included tests with air outside the pipe in addition to those with water. More uniform heating of the pipe was achieved with the water bath than with the light bulb, so it provided the better testing configuration of the two.

Some simple scoping hand calculations were done to determine the expected temperature drops through the pipe wall and from the outer pipe surface to the water in the tank. It was found that the drop through the pipe wall was approximately $10 \%$ of that from the wall to the fluid. Because the pinged thermocouple was located at the midpoint of the wall thickness, the implied error in interpreting the pinged-thermocouple temperature measurement as a surface measurement introduced only $\sim 5 \%$ error when comparing probe-thermocouple-to-fluid vs pinged-thermocouple-to-fluid temperature difference measurements. It is this temperature difference that is the data of interest since it allows an estimate of the heat source present in the ACB. Because the relative temperature drop from the pipe surface to air vs the drop through the wall is very large, the corresponding error in air is much less than $5 \%$.

The first tests performed were with water in the tank and the light bulb heat source. It was found that with the probe as originally constructed (i.e., no suction cups on the probe pins), there was a significant offset error between the probe-to-water and pinged-thermocouple-to-water temperature difference measurements. The offset error observed was $\sim 28 \%$ (i.e., the probe-to-water temperature difference was $28 \%$ less than the pinged-thermocouple value). This offset error was larger than 
EFG $96-6745$

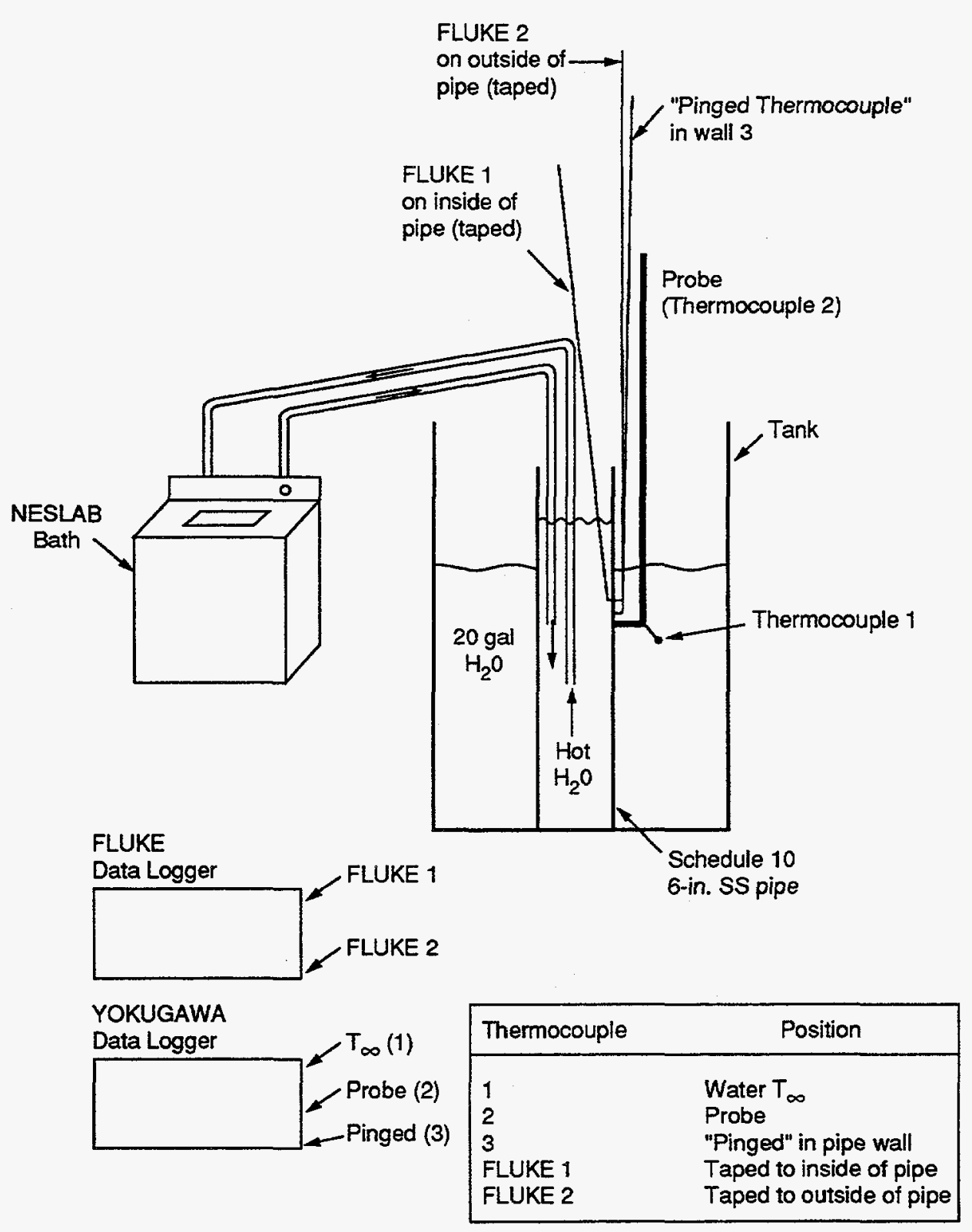

Fig. 10. Configuration of mock-up experiment. 
desired, so it was decided to try insulating the probe pins with Teflon tape. It was found that adding the Teflon tape had little effect on the offset error. Next, the position of the light bulb was adjusted to determine if its positioning affected the error. Unfortunately, it did not. Checks were also made for possible thermocouple channel calibration differences and thermocouple bias errors. However, none were found, and the offset error remained.

With the offset in water still unexplained, it was decided to perform some tests with air outside the pipe instead of water. The probe was first tested without the Teflon tape on the pins, and it was found that the relative offset error was about the same as that observed in the water tests. In an effort to reduce the error, rubber tubing was placed on the probe pins. A snug fit was obtained, with the tubing actually extending a little beyond the tip of the probe pins. Again, no significant reduction in the offset error occurred.

With the rubber tubing on the probe pins, the probe was tested in water. It was found that the offset error was reduced by about a factor of 2 (i.e., to $\sim 16 \%$ ). Because of concerns that the rubber tubing might make it difficult to establish good probe contact with the ACB column, the tubing was trimmed back from the tip of the probe pins to expose the tip portion. Unfortunately, tests with the trimmed tubing showed that the offset error increased, and was only a little less than that observed without the tubing.

Further testing was performed using the water bath as the heat source (and water in the tank). In the first test performed in this configuration, no insulation was placed on the probe pins. As expected, the resulting offset error was about the same as before when the light bulb heat source was used (i.e., $\sim 30 \%$ ). A portion of the temperature data recorded for this test with the Yokugawa data logger is provided in Fig. 11 and shows the significant offset error. Another type of probe pin insulation was then tried, which consisted of rubber suction cups with a cup diameter of $<1$ in. With the suction cups on the probe pins, the offset error was reduced to $\sim 10$ to $20 \%$. To reduce the problem of the suction cups sticking to the pipe wall, small holes were cut in the cups. No significant differences in test results were observed for the cups with holes vs without holes. A portion of the temperature data for the test in which suction cups with holes were used is provided in Fig. 12 and shows the reduced offset error. During this test, the probe was removed from the pipe surface for $\sim 10$ min to determine if its presence was affecting the pinged-thermocouple reading. No change in the pinged-thermocouple reading was observed. Within $\sim 1$ min after the probe was placed back against the pipe surface, the probe split junction thermocouple returned to the same reading it provided before the probe was moved. This test indicates that the presence of the probe does not significantly affect the pipe surface temperature after equilibrium conditions are established.

At this point, it was felt that a suitable correction factor could be applied to the measured ACB column surface-to-fluid temperature difference to obtain accurate data for finalized HEATING7 models. The necessary temperature measurements at the MSRE charcoal bed were completed on October 7, 1994, using the thermocouple probe fitted with suction cups. 
ORNL-DWG 95-3018R ETD

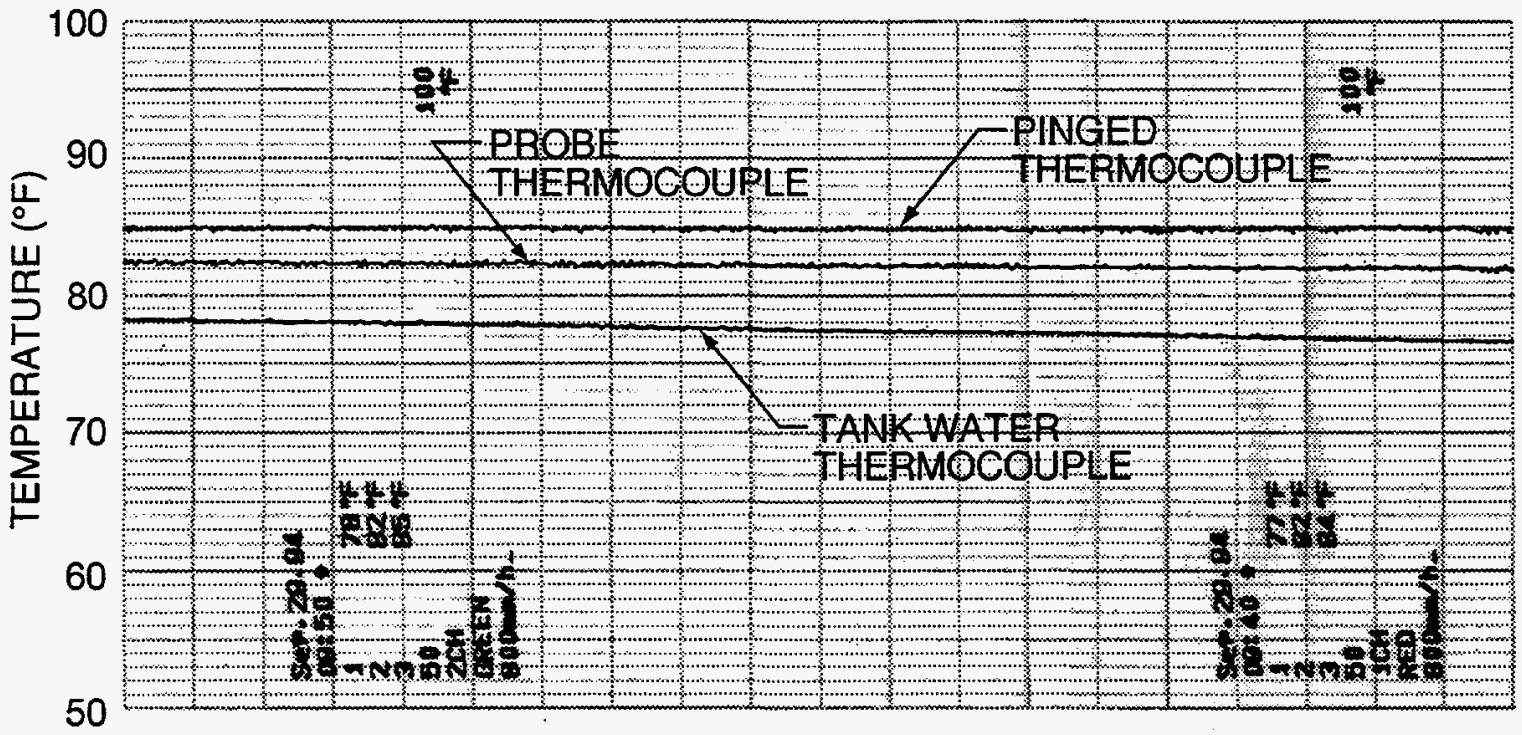

Fig. 11. Selected water, pinged-wall, and probe thermocouple readings showing the significant offset error associated with the probe without pin insulation.

ORNL-DWG 95-3017R ETD

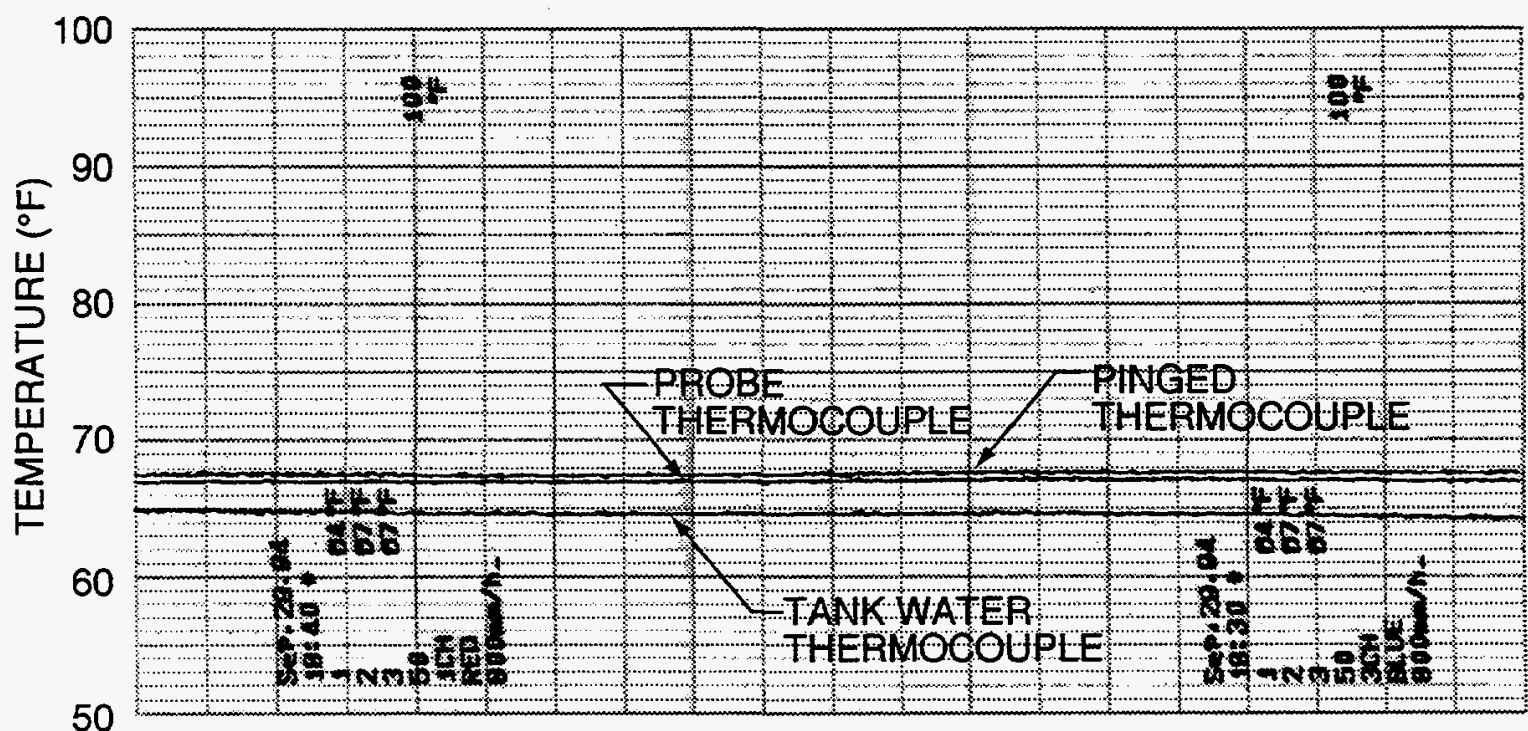

Fig. 12. Selected water, pinged-wall, and probe thermocouple readings showing the reduced offset error associated with the probe with suction cup insulation containing holes. 


\section{HEATING7 MODELS TO SUPPORT DRAINING OF THE CHARCOAL BED}

\subsection{BEST-ESTIMATE MODELS}

After shakedown testing of the probe was completed using the mock-up, temperature difference measurements were made at the ACB pipe on October 7, 1994. These thermocouple probe results are summarized in Table 2 . As shown in the table, the measurements were taken at 6-in. intervals for $\sim 5 \mathrm{ft}$ down the pipe. The temperature difference between the wall and the water appeared to decrease smoothly from $0.5^{\circ} \mathrm{F}$ at the top of the carbon column to $0.1^{\circ} \mathrm{F}$ at a location $2.5 \mathrm{ft}$ down. However, little information could be deduced about the possible presence of a plane heat source because of the wide measurement spacing.

Table 2. Results of the October 7, 1994, ACB wall temperature measurements ${ }^{a}$

\begin{tabular}{|c|c|c|c|}
\hline $\begin{array}{c}\text { Depth } \\
\text { (in.) }\end{array}$ & $\begin{array}{c}\text { Wall temperature } \\
\left({ }^{\circ} \mathrm{F}\right)\end{array}$ & $\begin{array}{c}\text { Ambient temperature } \\
\text { near pipe } \\
\left({ }^{\circ} \mathrm{F}\right)\end{array}$ & $\begin{array}{c}\text { Water temperature far from } \\
\text { pipe } \\
\left({ }^{\circ} \mathrm{F}\right)\end{array}$ \\
\hline 46 & 70.1 & 67.0 & 68.4 \\
48 & 68.5 & 68.0 & \\
52 & 68.3 & 68.0 & 68.4 \\
58 & 68.2 & 68.0 & \\
60 & 68.2 & 68.0 & 68.4 \\
64 & & 68.0 & \\
70 & 68.1 & 68.0 & 68.4 \\
72 & 68.1 & 68.0 & \\
76 & & 68.0 & 68.0 \\
82 & 68.1 & 68.0 & \\
84 & 68.1 & 67.9 & \\
88 & 68.1 & 67.9 & \\
94 & 68.0 & 68.0 & \\
96 & 68.0 & & \\
100 & & & \\
106 & & & \\
108 & & & \\
112 & & & \\
120 & & & \\
\hline
\end{tabular}

${ }^{a} \mathrm{ACB}$ thermocouple reading $=77.0^{\circ} \mathrm{F}$ on October $7,1994$.

A HEATING7.2 (Ref. 2) model was created to provide a "best-estimate" of the temperature changes associated with draining the ACB, based on the October 7,1994 , temperature measurements. The model was constructed in $\mathrm{r}-\mathrm{z}$ coordinates assuming azimuthal symmetry. It also assumed that the internal heat generation rate does not increase with rising temperature due to acceleration of any chemical reactions. According to B. D. Patton and D. W. Ramey from the Chemical Technology Division, this second condition should be satisfied as long as the centerline temperature does not exceed the prescribed maximum of $100^{\circ} \mathrm{C}$. The average heat transfer coefficients for natural convection in water and air were evaluated from McAdams's correlation ${ }^{7}$ for the Nusselt number in laminar flow: 


$$
N u_{a v}=\frac{h L}{k_{f}}=0.59 R a_{L}^{1 / 4}
$$

where $R a_{L}=\frac{g \beta\left(T_{s}-T_{\infty}\right) L^{3}}{\alpha v}$ is the Rayleigh number. The term " $L$ " in the correlation represents the heated length exposed to water or air cooling and varies over the course of the drain. Using $L=$ 30 in. gives a natural-convection coefficient of the form

$$
h=C\left(T_{\text {suface }}-T_{\text {ambient }}\right)^{1 / 4}
$$

where $C=19.0850$ for water cooling and $C=0.2494$ for cooling in air when $h$ is in units of $\mathrm{Btu} / \mathrm{h}-\mathrm{ft}^{2}-{ }^{\circ} \mathrm{F}$. An ambient temperature of $T_{\infty}=68^{\circ} \mathrm{F}$ was used for the water surrounding the pipe, and the air above the waterline was assumed to be at $T_{\infty}=70^{\circ} \mathrm{F}$. Heat transfer coefficients for natural convection in air tend to be so low that the heat transfer by thermal radiation is of comparable magnitude, even near room temperature. Thus, radiation effects were included on the portion of the pipe exposed to air using an average emissivity of $\varepsilon=0.50$, which was chosen as a reasonable average value for moderately oxidized stainless steel surfaces.

The internal heat generation incorporated into the best-estimate model was calculated by integrating the heat removal implied by the temperature measurements in Table 2 over the top $2.5 \mathrm{ft}$ of the carbon column using

$$
q_{\text {tot }}=\sum h_{i} A_{i} \Delta T_{i}
$$

The internal volumetric generation was then given by

$$
Q_{\text {gen }}=\frac{q_{\text {tot }}}{V_{\text {carbon }}}
$$

Carrying out these calculations yielded $q_{\text {tot }}=15.99 \mathrm{Btu} / \mathrm{h}(4.686 \mathrm{~W})$ for the total generation and $Q_{g e n}=29.043 \mathrm{Btu} / \mathrm{h}-\mathrm{ft}^{3}$ for the (uniform) volumetric rate. This value for the heat generation, together with the known $\mathrm{ACB}$ thermocouple reading of $77^{\circ} \mathrm{F}$, also allows an estimate to be made of the carbon thermal conductivity. Running the best-estimate model with $\mathrm{k}_{\text {charcoal }}$ treated as a parameter showed that a conductivity of $0.05 \mathrm{Btu} / \mathrm{h}-\mathrm{ft}-{ }^{\circ} \mathrm{F}$ was needed to match the known $\mathrm{ACB}$ reading. Although this conductivity is somewhat below the lowest numbers obtained from the literature ${ }^{3-5}$ it was used in all the best-estimate and limiting calculations because low conductivities lead to a conservatively high centerline temperature.

The best-estimate HEATING7.2 solution involved a set of 31 separate steady-state runs corresponding to the waterline in its original position and then lowering it in 1-in. increments during a total drain of 30 in. Heat transfer coefficients for water and air were scaled using 


$$
h=19.085\left(\frac{30 \text { in. }}{30 \text { in. }- \text { distance drained }}\right)^{1 / 4}\left(T_{s}-T_{\infty}\right)^{1 / 4} \quad \text { (water) }
$$

and

$$
h=0.2494\left(\frac{30 \text { in. }}{2.5 \text { in. }+ \text { distance drained }}\right)^{1 / 4}\left(T_{s}-T_{\infty}\right)^{1 / 4} \quad \text { (air) }
$$

The value for $h_{\text {water }}$ after draining $29 \mathrm{in}$. was also used at $30 \mathrm{in}$. to prevent a singularity problem. A schematic of the best-estimate model geometry and the HEATING input file for the initial water level prior to draining are presented in Appendix A to illustrate the modeling approach. Results from these calculations are summarized in Table 3 , which includes the maximum centerline temperature and its location, the maximum surface temperature and its location, the ACB thermocouple reading, and the surface temperatures 1 in. on either side of the waterline. Predictions for all these quantities are tabulated at 1-in. intervals over the entire course of the draining process, with both natural convection and radiative heat transfer taken into account. Based on the best-estimate calculations from Table 3 , one would expect the maximum surface temperatures to rise by $\sim 5^{\circ} \mathrm{F}$ and the centerline temperatures to go up by $\sim 6^{\circ} \mathrm{F}$ after draining. Thus, the best-estimate solution does not indicate any problems with exceeding the $100^{\circ} \mathrm{C}$ temperature limitation during draining of the ACB.

Because all these calculations were steady-state results, they show the maximum best-estimate temperatures that could be present at each level of the drain. However, it is still necessary to examine how much thermal lag would be introduced relative to the steady-state temperatures by the proposed procedure for draining the water. The proposed drain scheme involves pumping down the water level $1 \mathrm{in}$. over a 15 -min period, then waiting $1 \mathrm{~h}$ for the temperatures to equilibrate before draining another inch. Temperature measurements are planned $1 \mathrm{~h}$ into the waiting period for comparison with those predicted by the steady-state table. No more than a 6-in. decrease in water level will be attempted each day. A subroutine containing this algorithm for water level as a function of time, and including a conservative 4-h overnight wait, was incorporated into the HEATING7.2 model for transient calculations. These results are presented in Table 4 over the full 5-day period necessary to drain the water completely. Apparently, the largest thermal lag introduced by this drain scheme is $\sim 0.5^{\circ} \mathrm{F}$ relative to the best-estimate steady-state temperatures on the pipe centerline and $0.2^{\circ} \mathrm{F}$ on the convective surface. Such transient delays can be allowed for by comparing to both the best-estimate transient and steady-state tables as the water level is lowered. Some additional calculations that assumed a 2-h waiting period were also performed, and the results are collected in Table 5. They showed little reduction in the thermal lag relative to the $1-\mathrm{h}$ wait already proposed.

\subsection{CONSERVATIVE HEAT SOURCE MODELS}

Another set of HEATING simulations was carried out to provide a conservative limit for the pipe surface temperatures that would indicate an approach to the $100^{\circ} \mathrm{C}$ centerline limit. So that the new results would represent the maximum wall temperature differences that could lead to trouble if 
Table 3. Best-estimate steady-state temperatures at each state of draining the ACB, with radiative heat transfer ${ }^{a}$

\begin{tabular}{|c|c|c|c|c|c|c|c|c|c|}
\hline $\begin{array}{l}\text { Distance } \\
\text { drained } \\
\text { (in.) }\end{array}$ & $\begin{array}{l}\text { Maximum } \\
\text { centerline } \\
\text { temperature } \\
\left({ }^{\circ} \mathrm{F}\right)\end{array}$ & $\begin{array}{l}\text { Distance } \\
\text { below top } \\
\text { of charcoal } \\
\text { (in.) }\end{array}$ & $\begin{array}{l}\text { Location } \\
\text { relative to } \\
\text { current } \\
\text { waterline } \\
\text { (in.) }\end{array}$ & $\begin{array}{l}\text { Maximum } \\
\text { surface } \\
\text { temperature } \\
\left.\text { ( }{ }^{\circ} \mathrm{F}\right)\end{array}$ & $\begin{array}{l}\text { Distance } \\
\text { relative to } \\
\text { top of } \\
\text { charcoal } \\
\text { (in.) }\end{array}$ & $\begin{array}{c}\text { Distance } \\
\text { above } \\
\text { current } \\
\text { waterline } \\
\text { (in.) } \\
\end{array}$ & $\begin{array}{c}\mathrm{ACB} \\
\text { thermocouple } \\
\text { reading } \\
\left({ }^{\circ} \mathrm{F}\right)\end{array}$ & $\begin{array}{c}\text { Surface } \\
\text { temperature } \\
1 \text { in. above } \\
\text { waterline } \\
\left({ }^{\circ} \mathrm{F}\right)\end{array}$ & $\begin{array}{c}\text { Surface } \\
\text { temperature } \\
1 \text { in. below } \\
\text { waterline } \\
\left({ }^{\circ} \mathrm{F}\right)\end{array}$ \\
\hline 0 & 78.46 & 16.5 & -16.5 & 68.99 & +2.5 & 2.5 & 77.02 & 68.87 & 68.33 \\
\hline 1 & 78.46 & 16.5 & -15.5 & 69.47 & +2.5 & 3.5 & 77.13 & 69.18 & 68.38 \\
\hline 2 & 78.46 & 16.5 & -14.5 & 69.96 & +2.5 & 4.5 & 77.27 & 69.40 & 68.42 \\
\hline 3 & 78.46 & 16.0 & -13.0 & 70.44 & +2.5 & 5.5 & 77.50 & 69.61 & 68.45 \\
\hline 4 & 78.45 & 12.5 & -8.5 & 70.85 & +2.5 & 6.5 & 77.81 & 69.77 & 68.48 \\
\hline 5 & 78.57 & 7.0 & -2.0 & 71.19 & +1.0 & 6.0 & 78.22 & 69.90 & 68.49 \\
\hline 6 & 78.92 & 6.5 & -0.5 & 71.49 & +0.5 & 6.5 & 78.71 & 70.00 & 68.50 \\
\hline 7 & 79.43 & 6.5 & +0.5 & 71.76 & -1.0 & 6.0 & 79.24 & 70.07 & 68.50 \\
\hline 8 & 80.01 & 6.5 & +1.5 & 72.02 & -1.5 & 6.5 & 79.76 & 70.13 & 68.51 \\
\hline 9 & 80.57 & 6.5 & +2.5 & 72.25 & -2.0 & 7.0 & 80.21 & 70.17 & 68.51 \\
\hline 10 & 81.10 & 7.0 & +3.0 & 72.46 & -3.0 & 7.0 & 80.60 & 70.20 & 68.51 \\
\hline 11 & 81.59 & 7.0 & +4.0 & 72.65 & -3.5 & 7.5 & 80.92 & 70.23 & 68.50 \\
\hline 12 & 82.00 & 7.0 & +5.0 & 72.82 & -4.0 & 8.0 & 81.17 & 70.24 & 68.50 \\
\hline 13 & 82.36 & 7.5 & +5.5 & 72.97 & -4.5 & 8.5 & 81.38 & 70.26 & 68.50 \\
\hline 14 & 82.66 & 7.5 & +6.5 & 73.11 & -5.0 & 9.0 & 81.54 & 70.26 & 68.49 \\
\hline 15 & 82.91 & 8.0 & +7.0 & 73.23 & -5.5 & 9.5 & 81.67 & 70.27 & 68.49 \\
\hline
\end{tabular}


Table 3. (continued)

\begin{tabular}{|c|c|c|c|c|c|c|c|c|c|}
\hline $\begin{array}{l}\text { Distance } \\
\text { drained } \\
\text { (in.) }\end{array}$ & $\begin{array}{c}\text { Maximum } \\
\text { centerline } \\
\text { temperature } \\
\left({ }^{\circ} \mathrm{F}\right)\end{array}$ & $\begin{array}{l}\text { Distance } \\
\text { below top of } \\
\text { charcoal } \\
\text { (in.) }\end{array}$ & $\begin{array}{l}\text { Location } \\
\text { relative to } \\
\text { current } \\
\text { waterline } \\
\text { (in.) }\end{array}$ & $\begin{array}{l}\text { Maximum } \\
\text { surface } \\
\text { temperature } \\
\left({ }^{\circ} \mathrm{F}\right)\end{array}$ & $\begin{array}{l}\text { Distance } \\
\text { relative to } \\
\text { top of } \\
\text { charcoal } \\
\text { (in.) }\end{array}$ & $\begin{array}{c}\text { Distance } \\
\text { above } \\
\text { current } \\
\text { waterline } \\
\text { (in.) }\end{array}$ & $\begin{array}{l}\mathrm{ACB} \\
\text { thermocouple } \\
\text { reading }\left({ }^{\circ} \mathrm{F}\right)\end{array}$ & $\begin{array}{c}\text { Surface } \\
\text { temperature } \\
1 \text { in. above } \\
\text { waterline } \\
\left({ }^{\circ} \mathrm{F}\right)\end{array}$ & $\begin{array}{c}\text { Surface } \\
\text { temperature } \\
1 \text { in. below } \\
\text { waterline } \\
\left({ }^{\circ} \mathrm{F}\right)\end{array}$ \\
\hline 16 & 83.13 & 8.0 & +8.0 & 73.34 & -6.0 & 10.0 & 81.78 & 70.27 & 68.48 \\
\hline 17 & 83.31 & 8.5 & +8.5 & 73.44 & -6.5 & 10.5 & 81.86 & 70.27 & 68.47 \\
\hline 18 & 83.46 & 8.5 & +9.5 & 73.53 & -7.0 & 11.0 & 81.93 & 70.27 & 68.47 \\
\hline 19 & 83.60 & 9.0 & +10.0 & 73.61 & -7.5 & 11.5 & 81.98 & 70.27 & 68.46 \\
\hline 20 & 83.71 & 9.5 & +10.5 & 73.69 & -8.0 & 12.0 & 82.03 & 70.26 & 68.45 \\
\hline 21 & 83.81 & 9.5 & +11.5 & 73.75 & -8.5 & 12.5 & 82.07 & 70.26 & 68.44 \\
\hline 22 & 83.89 & 10.0 & +12.0 & 73.81 & -9.0 & 13.0 & 82.10 & 70.25 & 68.43 \\
\hline 23 & 83.97 & 10.5 & +12.5 & 73.87 & -9.5 & 13.5 & 82.12 & 70.24 & 68.42 \\
\hline 24 & 84.03 & 11.0 & +13.0 & 73.91 & -10.0 & 14.0 & 82.15 & 70.23 & 68.40 \\
\hline 25 & 84.09 & 11.0 & +14.0 & 73.96 & -10.5 & 14.5 & 82.17 & 70.21 & 68.39 \\
\hline 26 & 84.14 & 11.5 & +14.5 & 74.00 & -11.0 & 15.0 & 82.19 & 70.19 & 68.36 \\
\hline 27 & 84.18 & 12.0 & +15.0 & 74.04 & -11.5 & 15.5 & 82.20 & 70.16 & 68.33 \\
\hline 28 & 84.22 & 12.5 & +15.5 & 74.07 & -12.0 & 16.0 & 82.22 & 70.11 & 68.29 \\
\hline 29 & 84.26 & 13.5 & +15.5 & 74.10 & -12.5 & 16.5 & 82.23 & 70.02 & 68.22 \\
\hline 30 & 84.29 & 13.0 & +17.0 & 74.13 & -13.0 & 17.0 & 82.24 & 69.95 & 68.19 \\
\hline
\end{tabular}

${ }^{a}$ Results calculated using a uniform decay heat source $2.5 \mathrm{ft}$ long and $\mathrm{k}_{\text {charcoal }}=0.05 \mathrm{Btu} / \mathrm{h}-\mathrm{ft}-{ }^{\circ} \mathrm{F}$, based on the October 7 temperature measurements. (Four significant figures were used to show differences between the temperatures at each water level.) $\mathrm{T}_{\text {water }}=68^{\circ} \mathrm{F}, \mathrm{T}_{\text {air }}=70^{\circ} \mathrm{F}$. 
Table 4. Best-estimate transient temperatures $1 \mathrm{~h}$ after reaching each state of draining the ACB, with radiative heat transfer ${ }^{a}$

\begin{tabular}{|c|c|c|c|c|c|c|c|c|c|}
\hline $\begin{array}{l}\text { Distance } \\
\text { drained } \\
\text { (in.) }\end{array}$ & $\begin{array}{l}\text { Maximum } \\
\text { centerline } \\
\text { temperature } \\
\left({ }^{\circ} \mathrm{F}\right)\end{array}$ & $\begin{array}{c}\text { Distance } \\
\text { below top } \\
\text { of charcoal } \\
\text { (in.) }\end{array}$ & $\begin{array}{l}\text { Location } \\
\text { relative to } \\
\text { current } \\
\text { waterline } \\
\text { (in.) } \\
\end{array}$ & $\begin{array}{c}\text { Maximum } \\
\text { surface } \\
\text { temperature } \\
\left({ }^{\circ} \mathrm{F}\right)\end{array}$ & $\begin{array}{l}\text { Distance } \\
\text { relative to } \\
\text { top of } \\
\text { charcoal } \\
\text { (in.) } \\
\end{array}$ & $\begin{array}{l}\text { Distance } \\
\text { above } \\
\text { current } \\
\text { waterline } \\
\text { (in.) } \\
\end{array}$ & $\begin{array}{l}\mathrm{ACB} \\
\text { thermocouple } \\
\text { reading } \\
\left({ }^{\circ} \mathrm{F}\right)\end{array}$ & $\begin{array}{c}\text { Surface } \\
\text { temperature } \\
1 \text { in. above } \\
\text { waterline } \\
\left({ }^{\circ} \mathrm{F}\right) \\
\end{array}$ & $\begin{array}{c}\text { Surface } \\
\text { temperature } \\
1 \text { in. below } \\
\text { waterline } \\
\left({ }^{\circ} \mathbf{F}\right) \\
\end{array}$ \\
\hline 1 & 78.46 & 16.5 & -15.5 & 69.37 & +2.5 & 3.5 & 77.07 & 69.06 & 68.34 \\
\hline 2 & 78.46 & 16.5 & -14.5 & 69.81 & +2.5 & 4.5 & 77.13 & 69.24 & 68.37 \\
\hline 3 & 78.46 & 16.5 & -13.5 & 70.26 & +2.5 & 5.5 & 77.24 & 69.42 & 68.40 \\
\hline 4 & 78.46 & 16.5 & -12.5 & 70.65 & +2.5 & 6.5 & 77.43 & 69.57 & 68.41 \\
\hline 5 & 78.45 & 16.5 & -11.5 & 70.99 & +1.0 & 6.0 & 77.72 & 69.69 & 68.42 \\
\hline 6 & 78.45 & 16.0 & -10.0 & 71.36 & 0 & 6.0 & 78.13 & 70.14 & 68.57 \\
\hline 7 & 79.18 & 6.5 & +0.5 & 71.72 & -1.0 & 6.0 & 78.95 & 70.28 & 68.59 \\
\hline 8 & 79.56 & 6.5 & +1.5 & 71.94 & -2.0 & 6.0 & 79.30 & 70.32 & 68.59 \\
\hline 9 & 80.04 & 6.5 & +2.5 & 72.16 & -2.5 & 6.5 & 79.70 & 70.36 & 68.59 \\
\hline 10 & 80.53 & 7.0 & +3.0 & 72.36 & -3.0 & 7.0 & 80.10 & 70.40 & 68.59 \\
\hline 11 & 81.02 & 7.0 & +4.0 & 72.55 & -3.5 & 7.5 & 80.45 & 70.42 & 68.59 \\
\hline 12 & 81.45 & 7.0 & +5.0 & 72.72 & -4.0 & 8.0 & 80.75 & 70.44 & 68.59 \\
\hline 13 & 82.10 & 7.5 & +5.5 & 72.92 & -4.5 & 8.5 & 81.22 & 70.49 & 68.59 \\
\hline 14 & 82.29 & 7.5 & +6.5 & 73.03 & -5.0 & 9.0 & 81.31 & 70.48 & 68.58 \\
\hline 15 & 82.52 & 7.5 & +7.5 & 73.14 & -5.5 & 9.5 & 81.43 & 70.48 & 68.57 \\
\hline
\end{tabular}


Table 4. (continued)

\begin{tabular}{|c|c|c|c|c|c|c|c|c|c|}
\hline $\begin{array}{l}\text { Distance } \\
\text { drained } \\
\text { (in.) }\end{array}$ & $\begin{array}{l}\text { Maximum } \\
\text { centerline } \\
\text { temperature } \\
\left({ }^{\circ} \mathrm{F}\right)\end{array}$ & $\begin{array}{l}\text { Distance } \\
\text { below top of } \\
\text { charcoal } \\
\text { (in.) }\end{array}$ & $\begin{array}{c}\text { Location } \\
\text { relative to } \\
\text { current } \\
\text { waterline } \\
\text { (in.) }\end{array}$ & $\begin{array}{l}\text { Maximum } \\
\text { surface } \\
\text { temperature } \\
\left({ }^{\circ} \mathrm{F}\right)\end{array}$ & $\begin{array}{l}\text { Distance } \\
\text { relative to } \\
\text { top of } \\
\text { charcoal } \\
\text { (in.) }\end{array}$ & $\begin{array}{l}\text { Distance } \\
\text { above } \\
\text { current } \\
\text { waterline } \\
\text { (in.) }\end{array}$ & $\begin{array}{l}\mathrm{ACB} \\
\text { thermocouple } \\
\text { reading } \\
\left({ }^{\circ} \mathrm{F}\right)\end{array}$ & $\begin{array}{c}\text { Surface } \\
\text { temperature } \\
1 \text { in. above } \\
\text { waterline } \\
\left({ }^{\circ} \mathrm{F}\right)\end{array}$ & $\begin{array}{c}\text { Surface } \\
\text { temperature } \\
1 \text { in. below } \\
\text { waterline } \\
\left({ }^{\circ} \mathrm{F}\right) \\
\end{array}$ \\
\hline 16 & 82.74 & 8.0 & +8.0 & 73.25 & -6.0 & 10.0 & 81.55 & 70.48 & 68.57 \\
\hline 17 & 82.95 & 8.0 & +9.0 & 73.35 & -6.5 & 10.5 & 81.65 & 70.48 & 68.56 \\
\hline 18 & 83.13 & 8.5 & +9.5 & 73.44 & -7.0 & 11.0 & 81.75 & 70.48 & 68.55 \\
\hline 19 & 83.48 & 9.0 & +10.0 & 73.57 & -7.5 & 11.5 & 81.92 & 70.51 & 68.55 \\
\hline 20 & 83.53 & 9.0 & +11.0 & 73.63 & -8.0 & 12.0 & 81.95 & 70.49 & 68.54 \\
\hline 21 & 83.61 & 9.0 & +12.0 & 73.69 & -8.5 & 12.5 & 81.98 & 70.48 & 68.53 \\
\hline 22 & 83.70 & 9.5 & +12.5 & 73.74 & -9.0 & 13.0 & 82.01 & 70.47 & 68.51 \\
\hline 23 & 83.78 & 9.5 & +13.5 & 73.80 & -9.0 & 14.0 & 82.05 & 70.46 & 68.50 \\
\hline 24 & 83.86 & 10.0 & +14.0 & 73.85 & -9.5 & 14.5 & 82.08 & 70.45 & 68.49 \\
\hline 25 & 84.03 & 11.0 & +14.0 & 73.93 & -10.5 & 14.5 & 82.14 & 70.47 & 68.47 \\
\hline 26 & 84.05 & 11.0 & +15.0 & 73.96 & -10.5 & 15.5 & 82.15 & 70.43 & 68.45 \\
\hline 27 & 84.08 & 11.0 & +16.0 & 73.99 & -11.0 & 16.0 & 82.17 & 70.40 & 68.41 \\
\hline 28 & 84.12 & 11.5 & +16.5 & 74.03 & -11.5 & 16.5 & 82.18 & 70.35 & 68.36 \\
\hline 29 & 84.16 & 12.0 & +17.0 & 74.06 & -12.0 & 17.0 & 82.20 & 70.27 & 68.29 \\
\hline 30 & 84.20 & 12.0 & +18.0 & 74.09 & -12.5 & 17.5 & 82.21 & 70.17 & 68.25 \\
\hline
\end{tabular}

${ }^{a}$ Results calculated using a uniform decay heat source $2.5 \mathrm{ft}$ long and $\mathrm{k}_{\text {charcoal }}=0.05 \mathrm{Btu} / \mathrm{h}-\mathrm{ft}-{ }^{\circ} \mathrm{F}$, based on the October 7 temperature measurements. (Four significant figures were used to show differences between the temperatures at each water level.) $T_{\text {water }}=68^{\circ} \mathrm{F}, \mathrm{T}_{\text {air }}=70^{\circ} \mathrm{F}$. 
Table 5. Best-estimate transient temperatures $2 \mathrm{~h}$ after reaching each state of draining the $\mathrm{ACB}$, with radiative heat transfer ${ }^{a}$

\begin{tabular}{|c|c|c|c|c|c|c|c|c|c|}
\hline $\begin{array}{l}\text { Distance } \\
\text { drained } \\
\text { (in.) }\end{array}$ & $\begin{array}{l}\text { Maximum } \\
\text { centerline } \\
\text { temperature } \\
\left({ }^{\circ} \mathrm{F}\right)\end{array}$ & $\begin{array}{c}\text { Distance } \\
\text { below top } \\
\text { of charcoal } \\
\text { (in.) }\end{array}$ & $\begin{array}{l}\text { Location } \\
\text { relative to } \\
\text { current } \\
\text { waterline } \\
\text { (in.) }\end{array}$ & $\begin{array}{c}\text { Maximum } \\
\text { surface } \\
\text { temperature } \\
\left({ }^{\circ} \mathrm{F}\right)\end{array}$ & $\begin{array}{l}\text { Distance } \\
\text { relative to } \\
\text { top of } \\
\text { charcoal } \\
\text { (in.) }\end{array}$ & $\begin{array}{l}\text { Distance } \\
\text { above } \\
\text { current } \\
\text { waterline } \\
\text { (in.) }\end{array}$ & $\begin{array}{c}\mathrm{ACB} \\
\text { thermocouple } \\
\text { reading } \\
\left({ }^{\circ} \mathrm{F}\right)\end{array}$ & $\begin{array}{c}\text { Surface } \\
\text { temperature } \\
1 \text { in.above } \\
\text { waterline } \\
\left({ }^{\circ} \mathrm{F}\right)\end{array}$ & $\begin{array}{c}\text { Surface } \\
\text { temperature } \\
1 \text { in. below } \\
\text { waterline } \\
\left({ }^{\circ} \mathrm{F}\right)\end{array}$ \\
\hline 1 & 78.46 & 16.5 & -15.5 & 69.38 & +2.5 & 3.5 & 77.09 & 69.07 & 68.34 \\
\hline 2 & 78.46 & 16.5 & -14.5 & 69.86 & +2.5 & 4.5 & 77.19 & 69.26 & 68.38 \\
\hline 3 & 78.46 & 16.5 & -13.5 & 70.33 & +2.5 & 5.5 & 77.35 & 69.46 & 68.40 \\
\hline 4 & 78.46 & 16.5 & -12.5 & 70.74 & +2.5 & 6.5 & 77.60 & 69.61 & 68.42 \\
\hline 5 & 78.45 & 15.0 & -10.0 & 71.09 & +1.0 & 6.0 & 77.97 & 69.73 & 68.43 \\
\hline 6 & 78.78 & 6.5 & -0.5 & 71.49 & 0 & 6.0 & 78.53 & 70.22 & 68.59 \\
\hline 7 & 79.33 & 6.5 & +0.5 & 71.78 & -1.0 & 6.0 & 79.10 & 70.31 & 68.60 \\
\hline 8 & 79.89 & 6.5 & +1.5 & 72.03 & -2.0 & 6.0 & 79.60 & 70.37 & 68.60 \\
\hline 9 & 80.48 & 6.5 & +2.5 & 72.27 & -2.5 & 6.5 & 80.10 & 70.43 & 68.60 \\
\hline 10 & 80.95 & 7.0 & +3.0 & 72.46 & -3.0 & 7.0 & 80.44 & 70.46 & 68.60 \\
\hline 11 & 81.41 & 7.0 & +4.0 & 72.64 & -3.5 & 7.5 & 80.75 & 70.49 & 68.60 \\
\hline 12 & 81.81 & 7.0 & $\begin{array}{r}+5.0 \\
\end{array}$ & 72.81 & -4.0 & 8.0 & 81.01 & 70.51 & 68.60 \\
\hline 13 & 82.23 & 7.5 & +5.5 & 72.97 & -4.5 & 8.5 & 81.29 & 70.53 & 68.60 \\
\hline 14 & 82.49 & 7.5 & +6.5 & 73.09 & -5.0 & 9.0 & 81.42 & 70.54 & 68.59 \\
\hline 15 & 82.74 & 8.0 & +7.0 & 73.21 & -5.5 & 9.5 & 81.56 & 70.54 & 68.59 \\
\hline
\end{tabular}




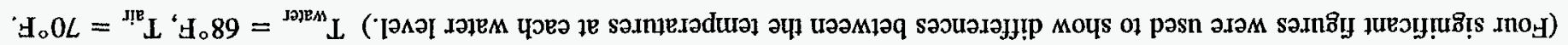

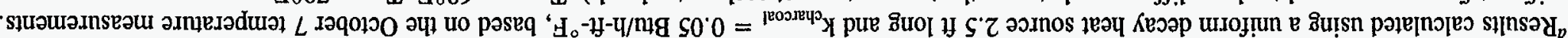

\begin{tabular}{|c|c|c|c|c|c|c|c|c|c|}
\hline $9 z^{\prime} 89$ & $\varepsilon Z^{\prime} 0 L$ & $\varepsilon z^{\prime} z 8$ & $0 \angle I$ & $0^{\circ} \varepsilon I^{-}$ & $I I^{\circ} t L$ & $0^{\circ} \angle I+$ & $0^{\prime} \varepsilon I$ & $9 Z^{\circ} \triangleright 8$ & $0 \varepsilon$ \\
\hline 6289 & $\nabla \varepsilon^{\circ} 0 L$ & 2728 & $S 9 I$ & s'zI- & $60^{\circ} \triangleright L$ & s'9It & $S Z I$ & $\varepsilon Z^{\circ} \downarrow 8$ & 62 \\
\hline$\angle E^{\prime} 89$ & $\overline{Z t^{\prime} 0 L}$ & $0 z^{\prime} 28$ & $0.9 I$ & $0^{\circ} \mathrm{ZI}^{-}$ & $s 0 \div L$ & $0^{\circ} 9 I+$ & $02 \mathrm{Zl}$ & $\angle I^{\circ} \triangleright 8$ & 82 \\
\hline 2789 & $9 \nabla^{\circ} 0 L$ & $81^{\prime} 78$ & $\overline{S^{\prime} \mathrm{SI}}$ & S'II- $^{-}$ & $20^{\circ} \nabla L$ & S.SIt & S'II & $\varepsilon I^{\prime} \downarrow 8$ & $\overline{L Z}$ \\
\hline St' 89 & $6 t^{\prime} 0 L$ & LI'Z8 & $0 . S I$ & $0^{\circ} \mathrm{II}^{-}$ & $86^{\circ} \varepsilon L$ & $0^{\circ} S I t$ & $0 . \mathrm{II}$ & $60^{\circ} 78$ & 92 \\
\hline $87^{\prime} 89$ & $Z S^{\prime} 0 L$ & SI'Z8 $^{\prime}$ & $S^{\prime} \triangleright I$ & $\mathrm{~S}^{\circ} 0 \mathrm{I}^{-}$ & $S 6 . \varepsilon L$ & $0 t+I+$ & 0.11 & SO't8 & $\mathcal{S Z}$ \\
\hline $0 S^{\prime} 89$ & $\overline{Z S^{\circ} 0 L}$ & $2 I^{\prime} Z 8$ & $0 \forall I$ & $0^{\circ} 0 \mathrm{I}^{-}$ & $68^{\circ} \varepsilon L$ & $\mathrm{~S}^{\prime} \varepsilon I+$ & S'0I & $96^{\circ} \varepsilon 8$ & $\overline{t z}$ \\
\hline IS'89 & $\overline{\varepsilon S^{\prime} 0 L}$ & $60^{\circ} \mathrm{z8}$ & $\bar{S} \mathcal{E} \mathrm{EI}$ & $s^{\prime} 6^{-}$ & $t 8^{\circ} \varepsilon L$ & $0^{\circ} \varepsilon I+$ & 0.01 & $68^{\circ} \varepsilon 8$ & $\mathcal{E Z}$ \\
\hline ES'89 & $\nabla S^{\prime} 0 L$ & $90^{\prime} 28$ & $0^{\prime} \varepsilon I$ & $0^{\circ} 6^{-}$ & $6 L \mathcal{E} L$ & $0^{\circ} \mathrm{ZI}+$ & $0^{\circ} 0 \mathrm{I}$ & $18^{\circ} \mathrm{EB}$ & $2 z$ \\
\hline$t S^{\prime} 89$ & $S S^{\prime} 0 L$ & $70^{\circ} z 8$ & $\bar{s} Z I$ & $S^{\prime} 8^{-}$ & $\nabla L^{\prime} \mathcal{E} L$ & SIIt & 5.6 & $\overline{S L^{\prime} \mathfrak{E} 8}$ & $I 2$ \\
\hline $\mathcal{S S}^{\circ} 89$ & $S S^{\circ} 0 L$ & $\angle 6^{\prime} 18$ & $0.2 I$ & $0.8-$ & $99^{\circ} \varepsilon L$ & $0^{\circ}$ IIt & 0.6 & $09^{\prime} \varepsilon 8$ & 02 \\
\hline $9 S^{\prime} 89$ & $S S^{\prime} 0 L$ & 26.18 & SII & $S^{\prime} L^{-}$ & $6 S^{\prime} \varepsilon L$ & $0^{\circ} 0 \mathrm{I}+$ & 06 & $\angle t^{\circ} \varepsilon 8$ & $6 \mathrm{I}$ \\
\hline$\angle S 89$ & $S S^{\prime} 0 L$ & 98' I8 & 0.II & $0^{\circ} L^{-}$ & $\mathfrak{I S}^{\prime} \varepsilon L$ & $5.6+$ & 58 & $\nabla \varepsilon^{\circ} \varepsilon 8$ & 81 \\
\hline$\angle S^{\prime} 89$ & $9 S^{\circ} 0 L$ & I8' 18 & $\overline{S ' 0 I}$ & $\varsigma^{*} 9^{-}$ & $\varepsilon b^{\prime} \varepsilon L$ & $58+$ & 58 & $Z Z^{\prime} \varepsilon 8$ & $L I$ \\
\hline 8589 & $\overline{S S^{\circ} 0 L}$ & $\angle 9^{\prime}$ I8 & $0.0 \mathrm{I}$ & $0^{\circ} 9^{-}$ & $Z E^{\prime} \mathcal{E} L$ & $08+$ & 0.8 & $\angle 6.28$ & 9 9I \\
\hline 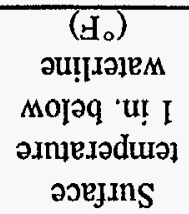 & 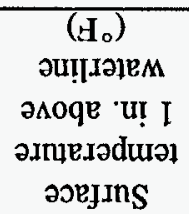 & 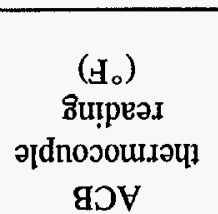 & 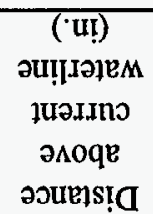 & 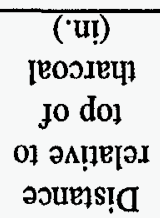 & 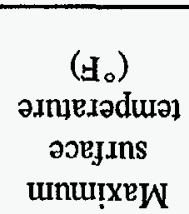 & 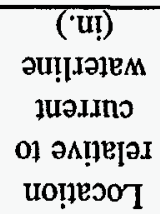 & 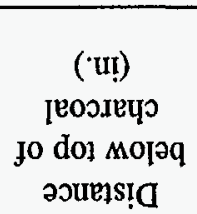 & 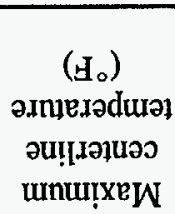 & 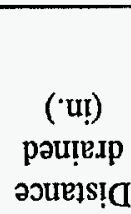 \\
\hline
\end{tabular}

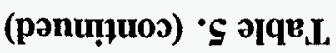


they were exceeded, the natural-convection heat transfer coefficients from McAdams's correlation were increased $30 \%$, and the radiation emissivity was changed to $\varepsilon=1.0$. Some initial scoping calculations assuming a planar heat source to be present between the 6-in. spacing of the October 7, 1994, measurements showed that this data separation was too wide to rule out a concentrated heat source that could exceed the allowable temperatures. Therefore, additional temperature measurements were taken with a 1 -in. axial spacing using the split junction thermocouple probe. According to $B$. D. Patton, the new closer spaced temperature measurements showed only small $\Delta T$ s between the pipe wall and water, so that concern about planar heat sources could be eliminated.

After the possibility of a plane source was discounted, the only limiting case that remained to be considered involved higher-than-expected homogeneous heat generation. First, the uniform internal heat generation rate that corresponded to a centerline temperature of $212^{\circ} \mathrm{F}\left(100^{\circ} \mathrm{C}\right)$ after fully draining the bed was determined, using conservative natural convection and radiation heat transfer parameters. The corresponding heat generation rate turned out to be $337.15 \mathrm{Btu} / \mathrm{h}-\mathrm{ft}^{3}$ with a total heat release rate of $54.40 \mathrm{~W}$. Using this level of heat generation, the steady-state temperature distribution for each inch of the drain was calculated as had already been done for the best-estimate case. Table 6 presents these homogeneous limiting results for comparison with the best estimate from Table 3. For the first few inches of the drain, the steady-state surface temperatures are not greatly different, but the limiting case predictions then increase rapidly. Use of the thermocouple probe should certainly be capable of distinguishing between the best-estimate situation and a homogeneous generation case that approaches the temperature limit. Transient temperature results using the limiting generation rate and conservative heat transfer coefficients are outlined in Table 7. The maximum centerline thermal lag relative to steady state seems to be $\sim 2^{\circ} \mathrm{F}$ with a 1 -h waiting period. Thus, heat-up delays apparently would not interfere with detection of unacceptably high heat generation inside the carbon column provided it is distributed homogeneously.

A peer review of both the best-estimate and limiting sets of calculations was performed by P. T. Williams and G. L. Yoder. Williams constructed an independent numerical model using the CFDS-FLOW3D code ${ }^{9}$ to verify selected HEATING cases, while Yoder checked all the input files for the HEATING7.2 models and performed some one-dimensional hand calculations to verify the code results. No discrepancies in the input files were detected. The CFDS-FLOW3D solution indicated almost the same thermal lag relative to the steady state that was calculated by HEATING. Full details of how the HEATING models were verified are given in Chapter 6 of this report.

Based on the thermal models summarized in this chapter, procedures were developed for removing the water from the $\mathrm{ACB}$, and draining commenced on October 25,1994 , following the schedule with a 1-h waiting period. A further set of calculations was also done in support of actual draining of the MSRE carbon bed. All the earlier transient and steady-state drain tables were based on an air temperature of $70^{\circ} \mathrm{F}$ above the water. With the onset of fall, the measured air temperature had fallen to $59^{\circ} \mathrm{F}$. Hence, the new set of steady-state results presented in Table 8 was prepared to guide the initial stages of the drain based on true air temperatures. Somewhat lower convective surface temperatures are predicted under the new conditions, but the conclusions detailed earlier remain essentially unchanged. 
Table 6. Conservative ${ }^{a}$ steady-state temperatures at each state of draining the $\mathrm{ACB}$, with radiative heat transfer [assumes a uniformly distributed heat generation rate $(54.4 \mathrm{~W})$ which results in reaching the $100^{\circ} \mathrm{C}$ carbon temperature limit at full drain] $]^{b}$

\begin{tabular}{|c|c|c|c|c|c|c|c|c|c|}
\hline $\begin{array}{l}\text { Distance } \\
\text { drained } \\
\text { (in.) }\end{array}$ & $\begin{array}{c}\text { Maximum } \\
\text { centerline } \\
\text { temperature } \\
\left({ }^{\circ} \mathrm{F}\right)\end{array}$ & $\begin{array}{l}\text { Distance } \\
\text { below top of } \\
\text { charcoal } \\
\text { (in.) }\end{array}$ & $\begin{array}{l}\text { Location } \\
\text { relative to } \\
\text { current } \\
\text { waterline } \\
\text { (in.) } \\
\end{array}$ & $\begin{array}{l}\text { Maximum } \\
\text { surface } \\
\text { temperature } \\
\left({ }^{\circ} \mathrm{F}\right)\end{array}$ & $\begin{array}{l}\text { Distance } \\
\text { relative to } \\
\text { top of } \\
\text { charcoal } \\
\text { (in.) } \\
\end{array}$ & $\begin{array}{c}\text { Distance } \\
\text { above } \\
\text { current } \\
\text { waterline } \\
\text { (in.) } \\
\end{array}$ & $\begin{array}{l}\mathrm{ACB} \\
\text { thermocouple } \\
\text { reading } \\
\left({ }^{\circ} \mathrm{F}\right)\end{array}$ & $\begin{array}{c}\text { Surface } \\
\text { temperature } \\
1 \text { in. above } \\
\text { waterline } \\
\left({ }^{\circ} \mathrm{F}\right)\end{array}$ & $\begin{array}{c}\text { Surface } \\
\text { temperature } \\
1 \text { in. below } \\
\text { waterline } \\
\left({ }^{\circ} \mathrm{F}\right)\end{array}$ \\
\hline 0 & 187.9 & 16.5 & -16.5 & 72.34 & +2.5 & 2.5 & 169.4 & 71.91 & 69.44 \\
\hline 1 & 187.9 & 16.5 & -15.5 & 74.42 & +2.5 & 3.5 & 169.8 & 73.39 & 69.69 \\
\hline 2 & 187.9 & 16.5 & -14.5 & 76.27 & +1.0 & 3.0 & 170.4 & 74.49 & 69.85 \\
\hline 3 & 187.8 & 16.5 & -13.5 & 78.02 & +0.5 & 3.5 & 171.3 & 75.64 & 69.96 \\
\hline 4 & 187.8 & 16.5 & -12.5 & 79.56 & -0.5 & 3.5 & 172.6 & 76.59 & 70.03 \\
\hline 5 & 187.8 & 16.0 & -11.0 & 81.24 & -1.5 & 3.5 & 174.4 & 77.34 & 70.07 \\
\hline 6 & 187.8 & 9.0 & -3.0 & 82.81 & -2.0 & 4.0 & 176.6 & 77.88 & 70.10 \\
\hline 7 & 189.3 & 7.5 & -0.5 & 84.20 & -2.5 & 4.5 & 179.0 & 78.29 & 70.11 \\
\hline 8 & 191.9 & 7.5 & +0.5 & 85.43 & -3.0 & 5.0 & 181.1 & 78.61 & 70.12 \\
\hline 9 & 194.8 & 7.5 & +1.5 & 86.52 & -4.0 & 5.0 & 183.0 & 78.84 & 70.11 \\
\hline 10 & 197.6 & 7.5 & +2.5 & 87.48 & -4.5 & 5.5 & 184.5 & 79.02 & 70.10 \\
\hline 11 & 200.0 & 8.0 & +3.0 & 88.30 & -5.0 & 6.0 & 185.6 & 79.15 & 70.09 \\
\hline 12 & 202.2 & 8.0 & +4.0 & 89.03 & -5.5 & 6.5 & 186.4 & 79.24 & 70.07 \\
\hline 13 & 204.0 & 8.5 & +4.5 & 89.66 & -6.0 & 7.0 & 187.1 & 79.31 & 70.05 \\
\hline 14 & 205.4 & 8.5 & +5.5 & 90.21 & -6.5 & 7.5 & 187.5 & 79.35 & 70.03 \\
\hline 15 & 206.6 & 9.0 & +6.0 & 90.69 & -7.0 & 8.0 & 187.9 & 79.38 & 70.00 \\
\hline
\end{tabular}


Table 6. (continued)

\begin{tabular}{|c|c|c|c|c|c|c|c|c|c|}
\hline $\begin{array}{c}\text { Distance } \\
\text { drained } \\
\text { (in.) }\end{array}$ & $\begin{array}{l}\text { Maximum } \\
\text { centerline } \\
\text { temperature } \\
\left({ }^{\circ} \mathrm{F}\right)\end{array}$ & $\begin{array}{l}\text { Distance } \\
\text { below top } \\
\text { of charcoal } \\
\text { (in.) }\end{array}$ & $\begin{array}{l}\text { Location } \\
\text { relative to } \\
\text { current } \\
\text { waterline } \\
\text { (in.) }\end{array}$ & $\begin{array}{c}\text { Maximum } \\
\text { surface } \\
\text { temperature } \\
\left({ }^{\circ} \mathrm{F}\right)\end{array}$ & $\begin{array}{l}\text { Distance } \\
\text { relative to } \\
\text { top of } \\
\text { charcoal } \\
\text { (in.) }\end{array}$ & $\begin{array}{l}\text { Distance } \\
\text { above } \\
\text { current } \\
\text { waterline } \\
\text { (in.) }\end{array}$ & $\begin{array}{c}\mathrm{ACB} \\
\text { thermocouple } \\
\text { reading } \\
\left({ }^{\circ} \mathrm{F}\right)\end{array}$ & $\begin{array}{c}\text { Surface } \\
\text { temperature } \\
1 \text { in. above } \\
\text { waterline } \\
\left({ }^{\circ} \mathrm{F}\right)\end{array}$ & $\begin{array}{c}\text { Surface } \\
\text { temperature } \\
1 \text { in. below } \\
\text { waterline } \\
\left({ }^{\circ} \mathrm{F}\right)\end{array}$ \\
\hline 16 & 207.6 & 9.5 & +6.5 & 91.11 & -7.5 & 8.5 & 188.1 & 79.40 & 69.97 \\
\hline 17 & 208.4 & 9.5 & +7.5 & 91.47 & -8.0 & 9.0 & 188.4 & 79.41 & 69.94 \\
\hline 18 & 209.0 & 10.0 & +8.0 & 91.80 & -8.5 & 9.5 & 188.5 & 79.41 & 69.91 \\
\hline 19 & 209.5 & 10.5 & +8.5 & 92.08 & -9.5 & 9.5 & 188.7 & 79.41 & 69.88 \\
\hline 20 & 210.0 & 11.0 & +9.0 & 92.33 & -10.0 & 10.0 & 188.8 & 79.40 & 69.84 \\
\hline 21 & 210.3 & 11.0 & +10.0 & 92.56 & -10.5 & 10.5 & 188.9 & 79.38 & 69.80 \\
\hline 22 & 210.7 & 11.5 & +10.5 & 92.75 & -11.0 & 11.0 & 189.0 & 79.35 & 69.75 \\
\hline 23 & 210.9 & 12.0 & +11.0 & 92.93 & -11.5 & 11.5 & 189.1 & 79.32 & 69.70 \\
\hline 24 & 211.1 & 12.5 & +11.5 & 93.08 & -12.0 & 12.0 & 189.1 & 79.27 & 69.64 \\
\hline 25 & 211.3 & 13.0 & +12.0 & 93.22 & -12.5 & 12.5 & 189.2 & 79.21 & 69.56 \\
\hline 26 & 211.5 & 13.0 & +13.0 & 93.35 & -13.0 & 13.0 & 189.3 & 79.11 & 69.47 \\
\hline 27 & 211.7 & 13.5 & +13.5 & 93.46 & -13.5 & 13.5 & 189.3 & 78.97 & 69.33 \\
\hline 28 & 211.8 & 14.0 & +14.0 & 93.57 & -13.5 & 14.5 & 189.4 & 78.72 & 69.13 \\
\hline 29 & 211.9 & 14.5 & +14.5 & 93.67 & -14.0 & 15.0 & 189.4 & 78.27 & 68.77 \\
\hline 30 & 212.0 & 14.5 & +15.5 & 93.75 & -14.5 & 15.5 & 189.5 & 77.69 & 68.57 \\
\hline
\end{tabular}

${ }^{a}$ Conservative means high effective heat transfer coefficients used, which reduces pipe surface-to-air and -water temperature differences. If it is assumed that the ACB thermocouple is not reliable, then exceeding these temperature differences could result in the carbon centerline temperature exceeding the $100^{\circ} \mathrm{C}$ temperature limit.

${ }^{b}$ Results calculated using a uniform decay heat source $2.5 \mathrm{ft}$ long and $\mathrm{k}_{\text {charcoal }}=0.05 \mathrm{Btu} / \mathrm{h}-\mathrm{ft}-^{\circ} \mathrm{F}$, based on the October 7 temperature measurements.

(Four significant figures were used to show differences between the temperatures at each water level.) $\mathrm{T}_{\text {water }}=68^{\circ} \mathrm{F}, \mathrm{T}_{\text {air }}=70^{\circ} \mathrm{F}$. 
Table 7. Conservative ${ }^{a}$ transient temperatures $1 \mathrm{~h}$ after reaching each state of draining the ACB, with radiative heat transfer [assumes a uniformly distributed heat generation rate $(54.4 \mathrm{~W})$ which results in reaching the

$100^{\circ} \mathrm{C}$ carbon temperature limit at full drain] $]^{b}$

\begin{tabular}{|c|c|c|c|c|c|c|c|c|c|}
\hline $\begin{array}{l}\text { Distance } \\
\text { drained } \\
\text { (in.) }\end{array}$ & $\begin{array}{l}\text { Maximum } \\
\text { centerline } \\
\text { temperature } \\
\left({ }^{\circ} \mathrm{F}\right)\end{array}$ & $\begin{array}{l}\text { Distance } \\
\text { below top of } \\
\text { charcoal } \\
\text { (in.) }\end{array}$ & $\begin{array}{l}\text { Location } \\
\text { relative to } \\
\text { current } \\
\text { waterline } \\
\text { (in.) }\end{array}$ & $\begin{array}{l}\text { Maximum } \\
\text { surface } \\
\text { temperature } \\
\left({ }^{\circ} \mathrm{F}\right)\end{array}$ & $\begin{array}{l}\text { Distance } \\
\text { relative to } \\
\text { top of } \\
\text { charcoal } \\
\text { (in.) }\end{array}$ & $\begin{array}{l}\text { Distance } \\
\text { above } \\
\text { current } \\
\text { waterline } \\
\text { (in.) } \\
\end{array}$ & $\begin{array}{c}\mathrm{ACB} \\
\text { thermocouple } \\
\text { reading } \\
\left({ }^{\circ} \mathrm{F}\right)\end{array}$ & $\begin{array}{c}\text { Surface } \\
\text { temperature } \\
1 \text { in. above } \\
\text { waterline } \\
\left({ }^{\circ} \mathrm{F}\right)\end{array}$ & $\begin{array}{c}\text { Surface } \\
\text { temperature } \\
1 \text { in. below } \\
\text { waterline } \\
\left({ }^{\circ} \mathrm{F}\right)\end{array}$ \\
\hline 1 & 187.87 & 16.5 & -15.5 & 74.08 & +2.5 & 3.5 & 169.62 & 72.93 & 69.56 \\
\hline 2 & 187.87 & 16.5 & -14.5 & 75.92 & +1.5 & 3.5 & 169.89 & 73.93 & 69.70 \\
\hline 3 & 187.86 & 16.5 & -13.5 & 77.65 & +0.5 & 3.5 & 170.40 & 74.99 & 69.78 \\
\hline 4 & 187.85 & 16.5 & -12.5 & 79.18 & 0 & 4.0 & 171.22 & 75.87 & 69.84 \\
\hline 5 & 187.83 & 16.5 & -11.5 & 80.80 & -1.5 & 3.5 & 172.48 & 76.56 & 69.87 \\
\hline 6 & 187.82 & 16.5 & -10.5 & 82.93 & -2.5 & 3.5 & 174.45 & 79.07 & 70.44 \\
\hline 7 & 188.53 & 8.0 & -1.0 & 84.41 & -3.0 & 4.0 & 177.87 & 79.62 & 70.48 \\
\hline 8 & 190.32 & 7.5 & +0.5 & 85.55 & -3.5 & 4.5 & 179.50 & 79.95 & 70.49 \\
\hline 9 & 192.81 & 7.5 & +1.5 & 86.57 & -4.0 & 5.0 & 181.27 & 80.21 & 70.49 \\
\hline 10 & 195.41 & 7.5 & +2.5 & 87.48 & -4.5 & 5.5 & 182.86 & 80.41 & 70.48 \\
\hline 11 & 197.82 & 7.5 & $\begin{array}{r}+3.5 \\
\end{array}$ & 88.27 & -5.0 & 6.0 & 184.19 & 80.56 & 70.47 \\
\hline 12 & 200.09 & 8.0 & +4.0 & 88.96 & -5.5 & 6.5 & 185.24 & 80.67 & 70.45 \\
\hline 13 & 202.96 & 8.0 & $\begin{array}{r}+5.0 \\
\end{array}$ & 89.66 & -6.0 & 7.0 & 186.64 & 80.81 & 70.44 \\
\hline 14 & 203.99 & 8.5 & $\begin{array}{r}+5.5 \\
\end{array}$ & 90.15 & -6.5 & 7.5 & 186.94 & 80.83 & 70.41 \\
\hline 15 & 205.12 & 8.5 & +6.5 & 90.60 & -7.0 & 8.0 & 187.31 & 80.87 & 70.38 \\
\hline
\end{tabular}


Table 7. (continued)

\begin{tabular}{|c|c|c|c|c|c|c|c|c|c|}
\hline $\begin{array}{c}\text { Distance } \\
\text { drained } \\
\text { (in.) }\end{array}$ & $\begin{array}{l}\text { Maximum } \\
\text { centerline } \\
\text { temperature } \\
\left({ }^{\circ} \mathrm{F}\right)\end{array}$ & $\begin{array}{l}\text { Distance } \\
\text { below top of } \\
\text { charcoal } \\
\text { (in.) }\end{array}$ & $\begin{array}{l}\text { Location } \\
\text { relative to } \\
\text { current } \\
\text { waterline } \\
\text { (in.) }\end{array}$ & $\begin{array}{l}\text { Maximum } \\
\text { surface } \\
\text { temperature } \\
\left({ }^{\circ} \mathrm{F}\right)\end{array}$ & $\begin{array}{l}\text { Distance } \\
\text { relative } \\
\text { to top of } \\
\text { charcoal } \\
\text { (in.) }\end{array}$ & $\begin{array}{l}\text { Distance } \\
\text { above } \\
\text { current } \\
\text { waterline } \\
\text { (in.) }\end{array}$ & $\begin{array}{l}\mathrm{ACB} \\
\text { thermocouple } \\
\text { reading } \\
\left({ }^{\circ} \mathrm{F}\right)\end{array}$ & $\begin{array}{c}\text { Surface } \\
\text { temperature } \\
1 \mathrm{in.} \text { above } \\
\text { waterline } \\
\left({ }^{\circ} \mathrm{F}\right)\end{array}$ & $\begin{array}{c}\text { Surface } \\
\text { temperature } \\
1 \text { in. below } \\
\text { waterline } \\
\left({ }^{\circ} \mathrm{F}\right)\end{array}$ \\
\hline 16 & 206.2 & 9 & +7.0 & 91.01 & -7.5 & 8.5 & 187.65 & 80.9 & 70.35 \\
\hline 17 & 207.11 & 9.5 & +7.5 & 91.37 & -8.0 & 9.0 & 187.94 & 80.92 & 70.32 \\
\hline 18 & 207.93 & 9.5 & +8.5 & 91.69 & -8.5 & 9.5 & 188.18 & 80.93 & 70.29 \\
\hline 19 & 209.15 & 10.0 & +9.0 & 92.04 & -9.5 & 9.5 & 188.54 & 81.00 & 70.26 \\
\hline 20 & 209.40 & 10.5 & +9.5 & 92.26 & -9.5 & 10.5 & 188.61 & 80.96 & 70.21 \\
\hline 21 & 209.74 & 10.5 & +10.5 & 92.47 & -10.0 & 11.0 & 188.71 & 80.95 & 70.16 \\
\hline 22 & 210.08 & 11.0 & +11.0 & 92.67 & -10.5 & 11.5 & 188.81 & 80.93 & 70.11 \\
\hline 23 & 210.39 & 11.5 & +11.5 & 92.84 & -11.0 & 12.0 & 188.91 & 80.92 & 70.05 \\
\hline 24 & 210.68 & 11.5 & +12.5 & 93.01 & -11.5 & 12.5 & 188.99 & 80.89 & 69.99 \\
\hline 25 & 211.17 & 12.5 & +12.5 & 93.19 & -12.0 & 13.0 & 189.13 & 80.91 & 69.91 \\
\hline 26 & 211.27 & 12.5 & +13.5 & 93.30 & -12.0 & 14.0 & 189.17 & 80.79 & 69.80 \\
\hline 27 & 211.40 & 13.0 & +14.0 & 93.41 & -13.0 & 14.0 & 189.23 & 80.65 & 69.65 \\
\hline 28 & 211.53 & 13.0 & +15.0 & 93.52 & -13.5 & 14.5 & 189.29 & 80.41 & 69.43 \\
\hline 29 & 211.67 & 13.5 & +15.5 & 93.62 & -14.0 & 15.0 & 189.35 & 79.94 & 69.04 \\
\hline 30 & 211.79 & 14.0 & +16.0 & 93.71 & -14.0 & 16.0 & 189.41 & 79.14 & 68.81 \\
\hline
\end{tabular}

${ }^{a}$ Conservative means high effective heat transfer coefficients used, which reduces pipe surface-to-air and -water temperature differences. If it is assumed that the $\mathrm{ACB}$ thermocouple is not reliable, then exceeding these temperature differences could result in the carbon centerline temperature exceeding the $100^{\circ} \mathrm{C}$ temperature limit.

${ }^{b}$ Results calculated using a heat source $2.5 \mathrm{ft}$ long and $\mathrm{k}_{\text {charcoal }}=0.05 \mathrm{Btu} / \mathrm{h}-\mathrm{ft}-{ }^{\circ} \mathrm{F}$, based on the October 7 temperature measurements. (Five significant figures were used to show differences between the temperatures at each water level.) $\mathrm{T}_{\text {water }}=68^{\circ} \mathrm{F}, \mathrm{T}_{\text {air }}=70^{\circ} \mathrm{F}$. 
Table 8. Best-estimate steady-state temperatures at each state of draining the ACB, with radiative heat transfer based on temperature measurements during the drain ${ }^{a}$

\begin{tabular}{|c|c|c|c|c|c|c|c|c|c|}
\hline $\begin{array}{c}\text { Distance } \\
\text { drained } \\
\text { (in.) }\end{array}$ & $\begin{array}{c}\text { Maximum } \\
\text { centerline } \\
\text { temperature } \\
\left({ }^{\circ} \mathrm{F}\right)\end{array}$ & $\begin{array}{c}\text { Distance } \\
\text { below top } \\
\text { of charcoal } \\
\text { (in.) }\end{array}$ & $\begin{array}{c}\text { Location } \\
\text { relative to } \\
\text { current } \\
\text { waterline } \\
\text { (in.) }\end{array}$ & $\begin{array}{c}\text { Maximum } \\
\text { surface } \\
\text { temperature } \\
\left({ }^{\circ} \mathrm{F}\right)\end{array}$ & $\begin{array}{c}\text { Distance } \\
\text { relative to } \\
\text { top of } \\
\text { charcoal } \\
\text { (in.) }\end{array}$ & $\begin{array}{c}\text { Distance } \\
\text { above } \\
\text { current } \\
\text { waterline } \\
\text { (in.) }\end{array}$ & $\begin{array}{c}\text { ACB } \\
\text { thermocouple } \\
\text { reading } \\
\left({ }^{\circ} \mathrm{F}\right)\end{array}$ & $\begin{array}{c}\text { Surface } \\
\text { temperature } \\
1 \text { in. above } \\
\text { waterline } \\
\left({ }^{\circ} \mathrm{F}\right)\end{array}$ & $\begin{array}{c}\text { Surface } \\
\text { temperature } \\
1 \text { in. below } \\
\text { waterline } \\
\left({ }^{\circ} \mathrm{F}\right)\end{array}$ \\
\hline 12 & 78.43 & 20.5 & -8.5 & 68.24 & -21.0 & -9.0 & 71.83 & 66.16 & 67.89 \\
\hline 13 & 78.42 & 21.0 & -8.0 & 68.24 & -21.5 & -8.5 & 71.68 & 66.19 & 67.90 \\
\hline 14 & 78.41 & 21.5 & -7.5 & 68.24 & -22.0 & -8.0 & 71.58 & 66.22 & 67.90 \\
\hline 15 & 78.40 & 22.0 & -7.0 & 68.23 & -22.5 & -7.5 & 71.50 & 66.24 & 67.91 \\
\hline 16 & 78.38 & 22.5 & -6.5 & 68.23 & -23.0 & -7.0 & 71.44 & 66.26 & 67.91 \\
\hline 17 & 78.36 & 23.0 & -6.0 & 68.23 & -23.5 & -6.5 & 71.40 & 66.28 & 67.92 \\
\hline 18 & 78.33 & 23.5 & -5.5 & 68.22 & -24.0 & -6.0 & 71.38 & 66.30 & 67.92 \\
\hline 19 & 78.28 & 24.0 & -5.0 & 68.22 & -24.5 & -5.5 & 71.36 & 66.32 & 67.92 \\
\hline 20 & 78.23 & 24.5 & -4.5 & 68.21 & -25.5 & -5.5 & 71.35 & 66.34 & 67.93 \\
\hline
\end{tabular}

${ }^{a}$ Results calculated using a uniform decay heat source $2.5 \mathrm{ft}$ long and $\mathrm{k}_{\text {charcoal }}=0.05 \mathrm{Btu} / \mathrm{h}-\mathrm{ft}{ }^{\circ} \mathrm{F}$, based on the October 7 temperature measurements. (Five significant figures were used to show differences between the temperatures at each water level.) $\mathrm{T}_{\text {water }}=68^{\circ} \mathrm{F}, \mathrm{T}_{\text {air }}=59^{\circ} \mathrm{F}$. 



\section{HEATING7 MODELS TO SUPPORT FILLING THE CHARCOAL BED CELL}

Once all the water had been drained from the MSRE charcoal bed, final comparisons could be made between the temperature increases calculated by the HEATING7 code ${ }^{2}$ and those actually measured in the charcoal bed cell (CBC). Two good areas for comparison are the ACB thermocouple reading on the charcoal centerline and the maximum temperature present on the outer surface of the pipe. The HEATING7 code predicted that the ACB temperature difference $T_{A C B}-T_{\infty}$ should increase from $7^{\circ} \mathrm{F}$ to $\sim 12^{\circ} \mathrm{F}$ upon completing the drain, with a maximum surface temperature difference of $4^{\circ} \mathrm{F}$. According to the actual measurements, $T_{A C B}-T_{\infty}$ increased from an initial value of $9^{\circ} \mathrm{F}$ to the 12 to $14^{\circ} \mathrm{F}$ range. The maximum surface temperature difference observed was $4.5^{\circ} \mathrm{F}$. Thus, the HEATNG7 models provided a good indication of the thermal effects associated with removing the water from the MSRE CBC.

Although removal of the water from the $\mathrm{CBC}$ eliminated the chances of a criticality accident, destructive fluorine reactions with the charcoal were still a serious concern. One possible way to avoid this problem involves filling the $\mathrm{CBC}$ with $\mathrm{CO}_{2}$ or vermiculite insulation to provide a chemically inert environment. However, changing the material in the cell would also alter the heat transport within the $\mathrm{CBC}$. These effects need to be addressed prior to the filling operation. Because the surface temperature differences for any given heat flux are larger and more easily measured in air, the new air $\Delta$ Ts are a more sensitive indication of the true heat source present in the charcoal. In particular, a source length of only 12 in. now seems more likely instead of the 30 -in. length inferred from the thermocouple data in water. This shorter source is also more consistent with the distribution determined independently from the nuclear radiation measurements and will be used in all the new thermal calculations.

\subsection{REFINEMENT OF THE HEAT SOURCE}

A new set of best-estimate and conservative cases for the heat generation in the MSRE ACB was developed based on the temperature measurements taken November 7,1994, and presented in Table 9. The measured surface-to-air temperature differences were integrated over the surface of the charcoal column using the McAdams natural-convection correlation for heated vertical surfaces ${ }^{7}$ :

$$
N u_{\alpha v}=\frac{h L}{k_{f}}=0.59 R a_{L}^{1 / 4}
$$

allowing a better estimate of the heat being rejected to the environment by convection. The radiative heat transfer was then obtained by a similar summation process. For the best-estimate case, the apparent $0.5^{\circ} \mathrm{F}$ bias in the November 7,1994 , temperature data was subtracted off, and the $\Delta \mathrm{Ts}$ were then increased by $30 \%$ to correct for the thermocouple measurement offset seen in mockup tests with the split junction thermocouple probe. The best-estimate radiation calculations were based on an overall emissivity value of $\varepsilon=0.7$ to provide the closest possible match to the new temperature data. The conservative calculations differed from the best estimate in that the assumed $0.5^{\circ} \mathrm{F}$ bias was not deducted, the heat transfer coefficients were increased $30 \%$ to account for uncertainty in the McAdams correlation, and $\varepsilon$ was assumed equal to 1.0 . 
Table 9. ACB temperature profile as measured in air on November 7, 1994

\begin{tabular}{|c|c|c|c|}
\hline $\begin{array}{c}\text { Depth } \\
\text { (in.) }\end{array}$ & $\begin{array}{c}\text { ACB sidewall } \\
\text { temperature from split } \\
\text { junction thermocouple } \\
\left({ }^{\circ} \mathrm{F}\right)\end{array}$ & $\begin{array}{c}\text { ACB sidewall estimated } \\
\text { infrared temperature } \\
\left({ }^{\circ} \mathrm{F}\right)\end{array}$ & $\begin{array}{c}\text { Ambient air } \\
\text { temperature } \\
\left({ }^{\circ} \mathrm{F}\right)\end{array}$ \\
\hline 44.5 & 63.1 & 62.5 & 61.4 \\
\hline 47 & 64.0 & 63.1 & 61.5 \\
\hline 49 & 64.5 & 63.6 & 61.6 \\
\hline 51 & 64.8 & 64.2 & 61.8 \\
\hline 53 & 64.5 & 65.0 & 61.8 \\
\hline 56 & 64.2 & 65.0 & 61.9 \\
\hline 59 & 63.8 & 64.4 & 62.0 \\
\hline 62 & 63.2 & 64.0 & 62.0 \\
\hline 65 & 63.1 & 63.1 & 62.1 \\
\hline 68 & 62.9 & 62.9 & 62.1 \\
\hline 71 & 62.6 & 62.6 & 62.1 \\
\hline 74 & 62.6 & 62.6 & 62.1 \\
\hline 77 & 63.0 & 62.6 & 62.6 \\
\hline 80 & 63.1 & 62.9 & 62.6 \\
\hline 81 & 63.1 & & 6 \\
\hline
\end{tabular}

The best-estimate calculations just described indicated that a total heat source of $2.36 \mathrm{~W}$ is present in the charcoal column, providing some independent corroboration of the $2.23-\mathrm{W}$ source expected from the amount of uranium implied by the nuclear radiation measurements. Using the conservative assumptions for the heat transfer parameters placed an upper limit on the source of $3.93 \mathrm{~W}$ based on thermal considerations. Finite difference 2-D r-z models were created using the HEATING7 code ${ }^{2}$ with both the best-estimate and the conservative heat generation rates. In all models, the heat generation was assumed to be homogeneously distributed over the top 12 in. of the ACB charcoal. An ambient temperature of $T_{\infty}=61.5^{\circ} \mathrm{F}$ was used for all convective surfaces more than $2 \mathrm{in}$. above the ACB-1 thermocouple plane. Lower points had $T_{\infty}=62.0^{\circ} \mathrm{F}$. In the best-estimate case, McAdams's correlation led to the natural-convection expressions:

$$
h=0.4200\left(T_{s}-T_{\infty}\right)^{1 / 4} \text { for air , }
$$

and

$$
h=0.2899\left(T_{s}-T_{\infty}\right)^{1 / 4} \quad \text { for } \mathrm{CO}_{2},
$$


where $h$ is expressed in Btu/h- $\mathrm{ft}^{2}-{ }^{\circ} \mathrm{F}$. These relations also incorporated a correction factor developed by Sparrow and Gregg ${ }^{10}$ to adjust McAdams's natural-convection coefficients for a vertical wall to an upright cylinder geometry. All surfaces exposed to air included radiation heat transfer with $\varepsilon=$ 0.7 , which seemed to fit the new thermocouple probe measurements taken in air more closely than the value of $\varepsilon=0.5$ used in previous best-estimate calculations.

The conservative case models used

$$
h=0.4550\left(T_{s}-T_{\infty}\right)^{1 / 4} \text { for air, }
$$

and

$$
h=0.3769\left(T_{s}-T_{\infty}\right)^{1 / 4} \text { for } \mathrm{CO}_{2}
$$

after including the correction to a cylindrical geometry. An emissivity of $\varepsilon=1.0$ was assumed for calculating radiation effects.

Results from these new HEATING7 models of the MSRE charcoal column and pipe are summarized in Table 10. For the best-estimate source strength distributed over 12 in., a charcoal conductivity of $0.0639 \mathrm{Btu} / \mathrm{h}-\mathrm{ft}-{ }^{\circ} \mathrm{F}$ gives an ACB thermocouple reading of $73.5^{\circ} \mathrm{F}$ (within $0.5^{\circ} \mathrm{F}$ of the $74^{\circ} \mathrm{F}$ temperature recorded on November 7 ). The conservative source indicated a conductivity of $0.1182 \mathrm{Btu} / \mathrm{h}-\mathrm{ft}-{ }^{\circ} \mathrm{F}$ for a similar match with the ACB data. Both these values for $\mathrm{k}_{\text {charcoal }}$ are reasonable compared to the literature, although the $0.0639 \mathrm{Btu} / \mathrm{h}-\mathrm{ft}-{ }^{\circ} \mathrm{F}$ value is a bit lower than the expected range of $\sim 0.08$ to $0.15 \mathrm{Btu} / \mathrm{h}-\mathrm{ft}-{ }^{\circ} \mathrm{F}{ }^{3-5}$ Two figures are provided comparing the wall temperature distribution predicted by the best-estimate HEATING7 model with the November 7 measurements. Figure 13 shows the calculated profile relative to raw data from the split junction thermocouple probe and infrared thermometer, while Fig. 14 plots the same profile together with split junction thermocouple probe data corrected for thermocouple bias and offset. As seen in both figures, the best-estimate model yields a quite good overall fit to the data.

To develop an additional HEATING7 model that would definitely lead to conservative centerline temperature predictions, the limiting heat source of $3.93 \mathrm{~W}$ was combined with a charcoal conductivity of only $0.05 \mathrm{Btu} / \mathrm{h}-\mathrm{ft}-{ }^{\circ} \mathrm{F}$ (lower than any literature value) for the third case included in Table 10. This case is consistent with all the measured parameters except the ACB thermocouple reading on the bed centerline. The third column of Table 10 shows the maximum centerline temperature in the charcoal for each of the three HEATING7 solutions with the pipe surrounded by air at $62^{\circ} \mathrm{F}$. Switching to $\mathrm{CO}_{2}$ at the same temperature changed these maximum temperatures by $<0.5^{\circ} \mathrm{F}$ for all three cases, as demonstrated by the last column of Table 10 .

\subsection{FILLING THE CBC WITH $\mathrm{CO}_{2}$ OR VERMICULITE}

Two-dimensional $r-z$ HEATING7 models of the entire ACB were also developed by building on an initial model created by K. W. Childs of the Computational Physics and Engineering Division to examine the maximum charcoal temperatures that might be present when the $\mathrm{CBC}$ is filled with air, $\mathrm{CO}_{2}$, or vermiculite. The geometry being considered is illustrated in Fig. 15 for the $\mathrm{CO}_{2}$ case and in Fig. 16 for vermiculite. The solutions for air and $\mathrm{CO}_{2}$ incorporated heat transfer by natural circulation in the region adjacent to the heated pipe, while the gas at the bottom of the CBC was assumed stagnant; in addition, heat transfer by radiation was included near the heated portion of the pipe. To model heat transfer within a cavity such as the $\mathrm{CBC}$, a new correlation is needed to include the 
Table 10. Creation of new best-estimate and conservative heat generation cases based on the November 7, 1994, temperature measurements

\begin{tabular}{|l|c|c|c|c|}
\hline $\begin{array}{c}\text { HEATING7 case } \\
\text { analyzed }\end{array}$ & $\begin{array}{c}\text { Total heat } \\
\text { source over } \\
12 \mathrm{in} . \\
(\mathrm{W})\end{array}$ & $\begin{array}{c}\text { Charcoal } \\
\text { conductivity } \\
\left(\mathrm{Btu} / \mathrm{h}-\mathrm{ft}-{ }^{\circ} \mathrm{F}\right)\end{array}$ & $\begin{array}{c}\text { Maximum ACB } \\
\text { centerline } \\
\text { temperature in air } \\
\text { at } 62^{\circ} \mathrm{F} \\
\left({ }^{\circ} \mathrm{F}\right)\end{array}$ & $\begin{array}{c}\text { Maximum ACB } \\
\text { centerline } \\
\text { temperature in } \\
\mathrm{CO}_{2} \text { at } 62^{\circ} \mathrm{F} \\
\left({ }^{\circ} \mathrm{F}\right)\end{array}$ \\
\hline Best estimate & 2.36 & 0.0639 & 74.45 & 74.80 \\
\hline Conservative source & 3.93 & 0.1182 & 74.45 & 74.67 \\
\hline $\begin{array}{l}\text { Conservative source } \\
\text { and conductivity }\end{array}$ & 3.93 & 0.05 & 86.14 & 86.36 \\
\hline
\end{tabular}

natural-convection coefficient from horizontal surfaces. From the work of McAdams, an appropriate equation for the Nusselt number on a horizontal surface is given by ${ }^{7}$

$$
N u_{a v}=\frac{h L}{k_{f}}=0.27 R a_{L}^{1 / 4} .
$$

Combining this expression with the other correlations for vertical cylinders yields the following heat transfer coefficients in Btu/h- $\mathrm{ft}^{2}{ }^{\circ} \mathrm{F}$ :

For the air case

$$
\begin{array}{ll}
h=0.3470\left(T_{s}-T_{\infty}\right)^{1 / 4} & \text { from the pipe to convective air, } \\
h=0.1148\left(T_{s}-T_{\infty}\right)^{1 / 4} & \text { from horizontal surfaces to convective air, and } \\
h=0.1989\left(T_{s}-T_{\infty}\right)^{1 / 4} & \text { from convective air to the CBC sidewalls. }
\end{array}
$$

For the $\mathrm{CO}_{2}$ case

$$
\begin{array}{ll}
h=0.2907\left(T_{s}-T_{\infty}\right)^{1 / 4} & \text { from the pipe to convective } \mathrm{CO}_{2}, \\
h=0.1008\left(T_{s}-T_{\infty}\right)^{1 / 4} & \text { from horizontal surfaces to convective } \mathrm{CO}_{2} \text {, and } \\
h=0.1745\left(T_{s}-T_{\infty}\right)^{1 / 4} & \text { from convective } \mathrm{CO}_{2} \text { to the } \mathrm{CBC} \text { sidewalls. }
\end{array}
$$

On the other hand, the vermiculite case was a pure conduction calculation using $k=0.0364 \mathrm{Btu} / \mathrm{h}-\mathrm{ft}-{ }^{\circ} \mathrm{F}$ for the vermiculite, ${ }^{11}$ with no convective or radiative heat transport involved. 


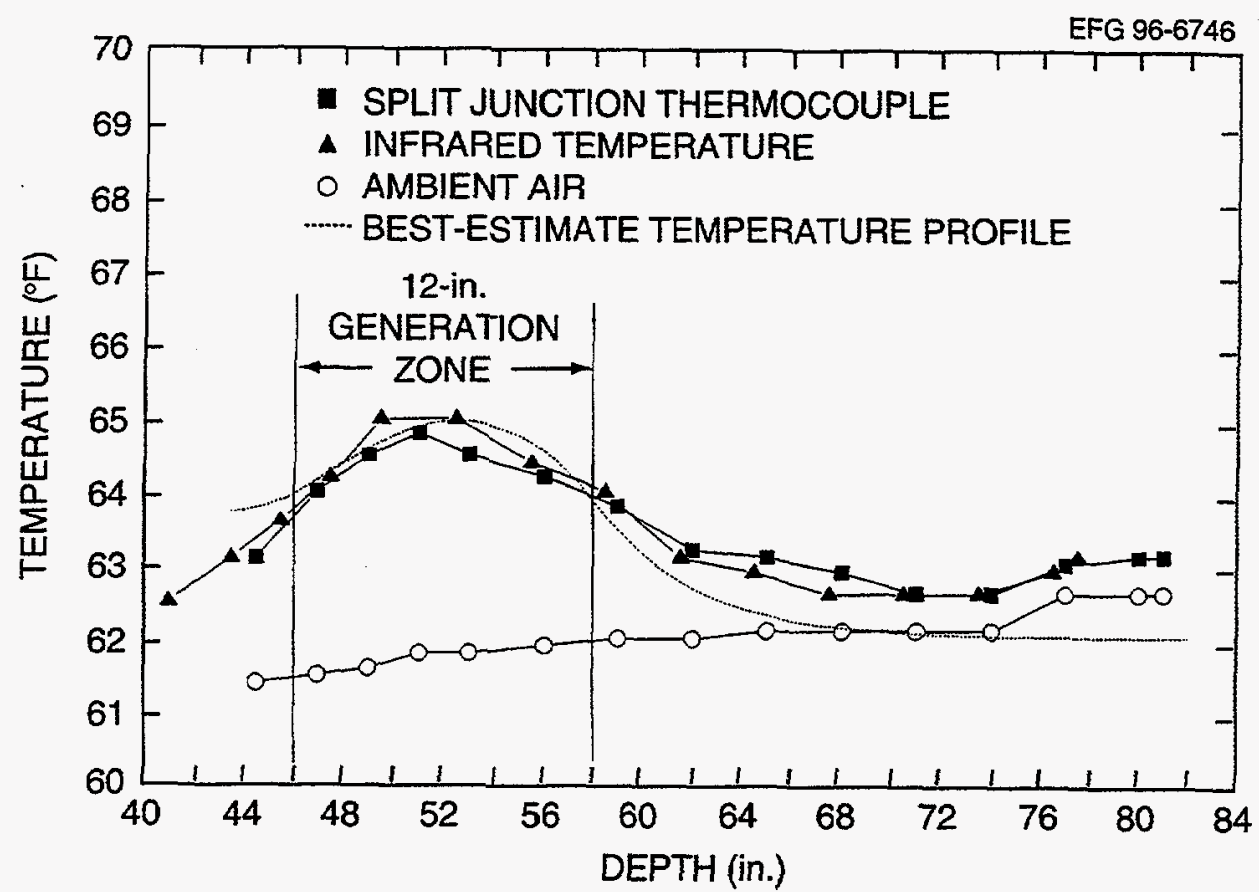

Fig. 13. Comparison of the calculated best-estimate temperature profile to the raw data from November 7,1994.

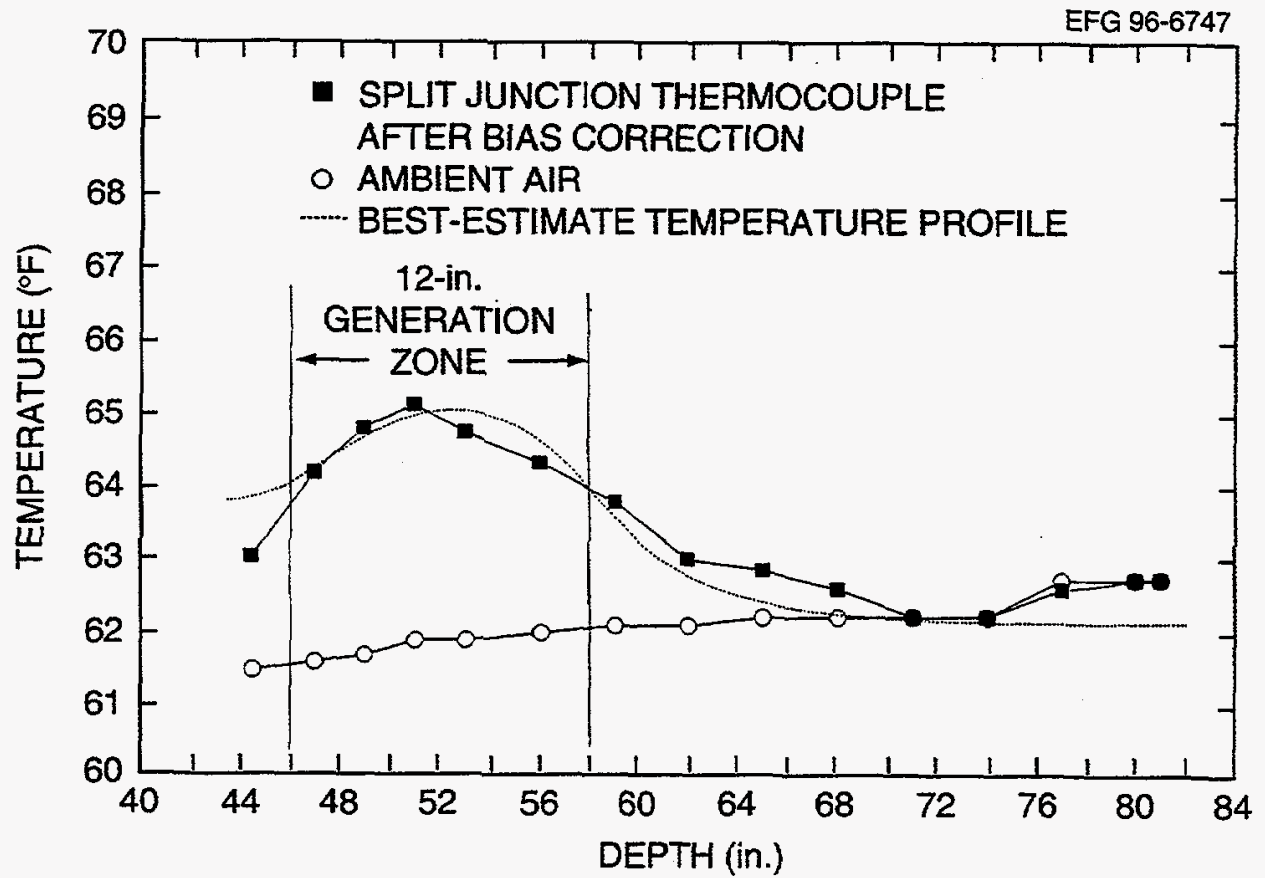

Fig. 14. Comparison of the calculated best-estimate profile to the split junction data after bias and offset correction. 


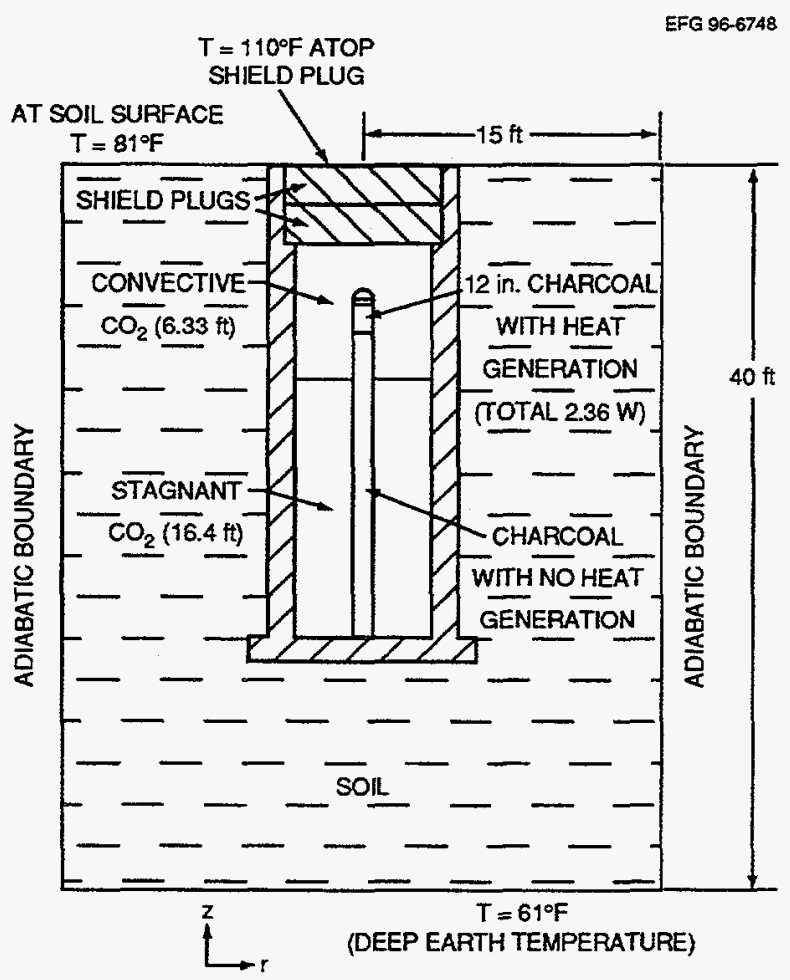

Fig. 15. Schematic of the $\mathrm{CBC}$ geometry analyzed for the $\mathrm{CO}_{2}$ case.

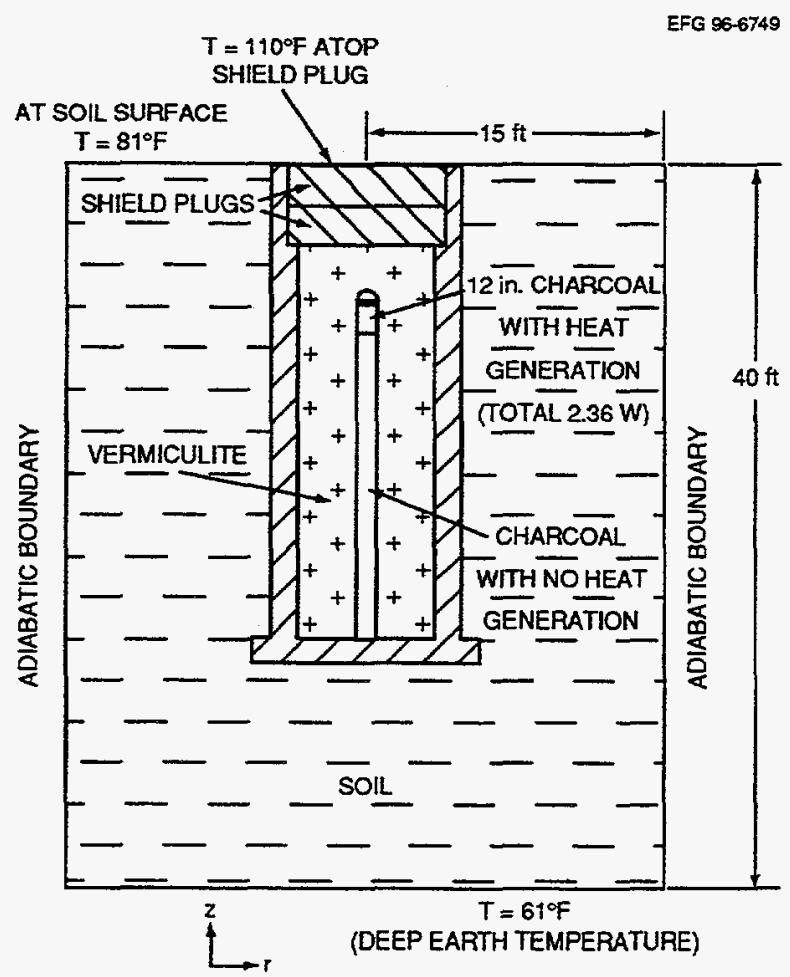

Fig. 16. Schematic of the CBC geometry analyzed for the vermiculite case. 
Boundary conditions applied to all three models reproduced the $61^{\circ} \mathrm{F}$ deep earth temperature characteristic of the Oak Ridge area ${ }^{12} 40 \mathrm{ft}$ below the surface. The grassy surface around the CBC was maintained at $81^{\circ} \mathrm{F}$, which is a conservative value for this region of the United States. ${ }^{12}$ Temperatures of either 100 or $110^{\circ} \mathrm{F}$ were assumed for the concrete surface of the upper shield plug. All these HEATING7 models are steady-state solutions that ignore any changes in the ground surface temperature over the course of the daily solar cycle. Thus, they definitely indicate conservative results.

Output from the HEATING7 code consisted of radial temperature distributions at each axial location. Results from these HEATING7 models of the whole CBC are collected in Table 11, including the mean filler temperature and the maximum temperature present in the charcoal for each case. As observed when the pipe alone was modeled, results are practically identical for either air or $\mathrm{CO}_{2}$ with equivalent temperature boundary conditions. The vermiculite calculations yielded a maximum charcoal temperature of $155.23^{\circ} \mathrm{F}$ for any of the cases studied. Best-estimate results with vermiculite filler showed a limiting value of $122.42^{\circ} \mathrm{F}$ in the $\mathrm{ACB}, \sim 23.6^{\circ} \mathrm{F}$ hotter than expected in air. All results presented in Table 11 were obtained assuming the charcoal-filled pipe extended to the bottom of the MSRE CBC, as shown in Figs. 15 and 16.

Table 11. Steady-state thermal analysis of MSRE cell

\begin{tabular}{|c|c|c|c|c|c|}
\hline $\begin{array}{c}\text { Filler } \\
\text { material }\end{array}$ & $\begin{array}{c}\text { Total heat } \\
\text { source over } \\
12 \text { in. } \\
(\mathrm{W})^{a}\end{array}$ & $\begin{array}{c}\text { Charcoal } \\
\text { conductivity } \\
\left(\mathrm{Btu} / \mathrm{h}-\mathrm{ft}-{ }^{\circ} \mathrm{F}\right)\end{array}$ & $\begin{array}{c}\text { Temperature } \\
\text { atop shield } \\
\text { plug } \\
\left({ }^{\circ} \mathrm{F}\right)\end{array}$ & $\begin{array}{c}\text { Mean filler } \\
\text { temperature } \\
\left({ }^{\circ} \mathrm{F}\right)\end{array}$ & $\begin{array}{c}\text { Maximum } \\
\text { charcoal } \\
\text { temperature } \\
\left({ }^{\circ} \mathrm{F}\right)\end{array}$ \\
\hline \multirow{2}{*}{ Air } & 2.36 & 0.0639 & 100 & 86.31 & 98.79 \\
& 2.36 & 0.0639 & 110 & 90.17 & 102.60 \\
& 3.93 & 0.1182 & 100 & 86.40 & 99.56 \\
& 3.93 & 0.1182 & 110 & 90.26 & 103.36 \\
& 3.93 & 0.05 & 100 & 86.40 & 111.49 \\
& 3.93 & 0.05 & 110 & 90.26 & 115.29 \\
\hline \multirow{2}{*}{$\mathrm{CO}_{2}$} & 2.36 & 0.0639 & 100 & 86.33 & 98.94 \\
& 2.36 & 0.0639 & 110 & 90.20 & 102.75 \\
& 3.93 & 0.1182 & 100 & 86.42 & 99.80 \\
& 3.93 & 0.1182 & 110 & 90.29 & 103.59 \\
& 3.93 & 0.05 & 100 & 86.42 & 111.74 \\
& 3.93 & 0.05 & 110 & 90.29 & 115.53 \\
\hline \multirow{2}{*}{ Vermiculite } & 2.36 & 0.0639 & 100 & & 122.42 \\
& 2.36 & 0.0639 & 110 & & 126.24 \\
& 3.93 & 0.1182 & 100 & & 138.64 \\
& 3.93 & 0.1182 & 110 & & 142.42 \\
& 3.93 & 0.05 & 100 & & 151.42 \\
& 3.93 & 0.05 & 110 & & 155.23 \\
\hline
\end{tabular}

${ }^{a} 2.36 \mathrm{~W}$ is the best-estimate heat generation rate and $3.93 \mathrm{~W}$ is the conservative one. 
Like the analysis to support draining of the charcoal bed, the new model development and numerical calculations were peer reviewed by P. T. Williams (Computational Physics and Engineering Division) and G. L. Yoder (Engineering Technology Division). Williams built independent numerical models for the pipe and the entire charcoal bed using the CFDS-FLOW3D ${ }^{9}$ and TOPAZ ${ }^{13}$ codes. Yoder reviewed creation of the best-estimate and conservative HEATING7 cases and the assumptions involved, as well as checking all the input files. No significant discrepancies were detected. Chapter 6 describes the independent verification of these results in much greater detail. 


\section{VERIFICATION AND BENCHMARKING OF HEATING MODELS}

Check and review studies of the HEATING7.2 results used to predict temperature distributions within an ACB and its associated concrete cell in the MSRE were performed. The upper portion of this ACB is presumed to have internal heat generation due to decay heat from ${ }^{233} U,{ }^{232} U$ (and daughters), and possibly chemical reaction sources. The steady-state and transient models of the ACB draining process are discussed in Chapter 4, and the cell-filling models are presented in Chapter 5. Each review consisted of two parts: (1) a check of the HEATING7.2 code input and modelling assumptions and (2) an independent series of calculations using the CFDS-FLOW3D and TOPAZ codes.

\subsection{STEADY-STATE MODELS}

The steady-state models analyzed the draining process as it progressed from the original water level to the bottom region where decay/chemical heat was expected (decay/chemical heat generation was assumed to be present within the charcoal bed in a region extending from the bottom of the steel wool to 30 in. below the bottom of the steel wool). Drain cases were run assuming various surface heat transfer conditions and heat loads.

For each series of runs, detailed checks of selected HEATING7.2 input decks were carried out to ensure that the geometry was properly modeled, the materials were properly characterized, and the volumetric heat generation corresponded to the assumed total decay/chemical heating rates. Boundary condition input was also checked for appropriate location and representation. These checks involved evaluating natural-convection heat transfer coefficients for water and air (including property checks) to ensure that the proper heat transfer coefficients were being used (e.g., to ensure that the flow was laminar, the Rayleigh number was checked). Comparisons of heat transfer coefficients were made to an alternate correlation for laminar flow natural-convection heat transfer. Spot checks of relevant altered input parameters were made for all of the runs.

A one-dimensional heat-conduction calculation was also made to ensure that the HEATING7.2 models were calculating reasonable centerline temperature distributions. The check was performed for two cases: one with the water at its original level and the second with the water level lowered 30 in. Both comparisons were made at a point 18 in. below the original water level to eliminate as many two-dimensional effects as possible. These comparisons showed a difference in centerline temperature between the one-dimensional model and the HEATING7.2 model of $<0.1^{\circ} \mathrm{F}$ for the original water level (check of $A C B$ to water heat transfer) and $<0.45^{\circ} \mathrm{F}$ for the case where the water level was lowered 30 in. (check of ACB to air heat transfer), showing that the model calculations were providing reasonable temperature results.

A heat conduction model of the MSRE ACB was also developed for the CFDS-FLOW3D code. ${ }^{9}$ Although primarily used for computational fluid dynamics applications, the conjugate heat transfer features of CFDS-FLOW3D provide for an analysis of heat conduction in solids that is comparable to HEATING7.2 calculations. Detailed convective and radiative boundary conditions and temperature-dependent thermophysical property data were implemented through user-supplied subroutines. The model included the charcoal bed, stainless steel pipe, stainless steel wool above the charcoal, and the thermocouple thermowell. Both convective and radiative boundary conditions were applied to surfaces exposed to air, and a natural-convection boundary condition was used for surfaces exposed to water. For the best-estimate cases, the total decay heat was $4.72 \mathrm{~W}$ distributed uniformly over a distance of $2.5 \mathrm{ft}$ below the top of the charcoal bed. This decay heat rate gave a temperature of $77.0^{\circ} \mathrm{F}$ at the thermocouple location 6 in. below the top of the charcoal. The 
conservative-estimate (homogeneous-limiting) cases used a decay heat rate of $54.4 \mathrm{~W}$. Higher effective heat transfer coefficients were also used in the conservative-estimate cases to reduce the pipe surface-to-air and surface-to-water temperature differences.

The best-estimate and conservative CFDS-FLOW3D calculations (shown in Tables 12 and 13) were compared to results from the HEATING7.2 models. Discretization studies were performed to ensure mesh independence for the solutions. Seven cases for both the best-estimate and conservative models were run to calculate steady-state temperature distributions for a full range of water levels that would occur during draining of the pool. In terms of distance drained (or distance below the initial water level), the check calculations included water levels at $0,4,5,15,16,29$, and $30 \mathrm{in}$. For each run, global heat balances and iteration histories of the residuals for the energy equation were monitored to ensure convergence to a steady-state solution.

The results of these steady-state CFDS-FLOW3D calculations were compared to results from the HEATING7.2 model. For each distance drained, the following data were selected for comparison: (1) maximum centerline temperature and its location, (2) maximum surface temperature and its location, (3) ACB thermocouple reading, and (4) surface temperatures $1 \mathrm{in}$. below and $1 \mathrm{in.}$ above the current waterline. The printer output file from CFDS-FLOW3D provides a resolution of three significant figures in its temperature maps. When compared to the HEATING7.2 results, the CFDSFLOW3D solutions agreed to within $\pm 0.1^{\circ} \mathrm{F}$ for all cases. For those locations where the maximum temperatures could be resolved at a single material control volume, the CFDS-FLOW3D results agreed with the HEATNG7.2 model to within \pm 0.2 in. In some cases, the CFDS-FLOW3D maximum temperature was located within a temperature distribution that was uniform (for the three significant-figure resolution in the output temperature map) over a certain length of the bed. The HEATING7.2 results for these cases were consistent with the CFDS-FLOW3D solutions, although it was not possible to determine the exact location of the maximum temperature from the CFDS-

FLOW3D output. As a final check, the 30-in. best-estimate case was rerun using a total decay heat of $4.686 \mathrm{~W}$ (instead of $4.72 \mathrm{~W}$ ) to match the decay heat level determined independently by the HEATING7.2 model. The temperature differences between the HEATING7.2 and CFDS-FLOW3D results were within $\pm 0.1^{\circ} \mathrm{F}$.

The steady-state model, described above, was modified to simulate filling of the drained pool with either air or $\mathrm{CO}_{2}$. These modifications involved applying the decay heat uniformly to the top $12 \mathrm{in.} \mathrm{of} \mathrm{the} \mathrm{carbon} \mathrm{column.} \mathrm{For} \mathrm{all} \mathrm{surfaces} \mathrm{above} \mathrm{a} \mathrm{horizontal} \mathrm{plane} \mathrm{located} 2 \mathrm{in}$. above the ACB thermocouple position, the ambient temperature was set to $61.5^{\circ} \mathrm{F}$. Below this plane, the ambient temperature was $62.0^{\circ} \mathrm{F}$. The new best-estimate case assumed a total decay heat of $2.36 \mathrm{~W}$, charcoal thermal conductivity of $0.0639 \mathrm{Btu} / \mathrm{h}-\mathrm{ft}-{ }^{\circ} \mathrm{F}$, and surface emissivity of 0.7 . The new conservative case assumed a total decay heat of $3.93 \mathrm{~W}$, charcoal thermal conductivity of $0.05 \mathrm{Btu} / \mathrm{h}-\mathrm{ft}-{ }^{\circ} \mathrm{F}$, and surface emissivity of 1.0. Correlations for natural-convection coefficients of the form

$$
h=C\left(T_{\text {surface }}-T_{\text {ambient }}\right)^{0.25}
$$

were applied to the model, where $C$ was defined in best-estimate and conservative cases: 
Table 12. CFDS-FLOW3D best-estimate steady-state temperatures at each state of draining the ACB ${ }^{a}$

\begin{tabular}{|c|c|c|c|c|c|c|c|c|c|}
\hline $\begin{array}{l}\text { Distance } \\
\text { drained } \\
\text { (in.) }\end{array}$ & $\begin{array}{c}\text { Maximum } \\
\text { centerline } \\
\text { temperature } \\
\left({ }^{\circ} \mathrm{F}\right)\end{array}$ & $\begin{array}{l}\text { Distance } \\
\text { below } \\
\text { top of } \\
\text { charcoal }^{b} \\
\text { (in.) }\end{array}$ & $\begin{array}{l}\text { Location } \\
\text { relative to } \\
\text { current } \\
\text { waterline } \\
\text { (in.) }\end{array}$ & $\begin{array}{l}\text { Maximum } \\
\text { surface } \\
\text { temperature } \\
\left({ }^{\circ} \mathrm{F}\right)\end{array}$ & $\begin{array}{l}\text { Distance } \\
\text { relative } \\
\text { to top of } \\
\text { charcoal }^{b} \\
\text { (in.) }\end{array}$ & $\begin{array}{l}\text { Distance } \\
\text { above } \\
\text { current } \\
\text { waterline }^{b} \\
\text { (in.) }\end{array}$ & $\begin{array}{c}\mathrm{ACB} \\
\text { thermocouple } \\
\text { reading } \\
\left({ }^{\circ} \mathrm{F}\right)\end{array}$ & $\begin{array}{c}\text { Surface } \\
\text { temperature } \\
1 \text { in. above } \\
\text { waterline } \\
\left({ }^{\circ} \mathrm{F}\right)\end{array}$ & $\begin{array}{c}\text { Surface } \\
\text { temperature } \\
1 \text { in. below } \\
\text { waterline } \\
\left({ }^{\circ} \mathrm{F}\right)\end{array}$ \\
\hline 0 & 78.4 & 15.8 & -15.8 & 69.0 & 2.2 & 2.2 & 77.0 & 68.9 & 68.3 \\
\hline 4 & 78.4 & 10.6 & -6.6 & 70.9 & 1.6 & 5.6 & 77.8 & 69.9 & 68.5 \\
\hline 5 & 78.5 & 7.1 & -2.1 & 71.2 & 1.2 & 6.2 & 78.2 & 70.0 & 68.6 \\
\hline 15 & 82.8 & 7.9 & 7.1 & 73.2 & -5.5 & 9.4 & 81.7 & 70.2 & 68.5 \\
\hline 16 & 83.0 & 8.1 & 7.9 & 73.4 & -5.9 & 10.1 & 81.8 & 70.2 & 68.5 \\
\hline 29 & 84.2 & 13.0 & 16.0 & 74.1 & -13.2 & 15.8 & 82.2 & 70.1 & 68.2 \\
\hline 30 & 84.2 & 13.0 & 17.1 & 74.2 & -13.3 & 16.7 & 82.2 & 70.1 & 68.2 \\
\hline $30^{c}$ & 84.1 & 13.0 & 17.1 & 74.1 & -13.1 & 16.9 & 82.2 & 70.1 & 68.2 \\
\hline
\end{tabular}

${ }^{a}$ Results calculated using a uniform decay heat source $2.5 \mathrm{ft}$ long and $\mathrm{k}_{\text {charcoal }}=0.05 \mathrm{Btu} / \mathrm{h}-\mathrm{ft}-{ }^{\circ} \mathrm{F}$, based on the October 7 temperature measurements. (Two significant figures were used to show differences between the temperatures at each water level.) $\mathrm{T}_{\text {water }}=68^{\circ} \mathrm{F}, \mathrm{T}_{\text {air }}=70^{\circ} \mathrm{F}$.

${ }^{b}$ Distances are best estimates based on resolution (two significant figures) of temperature distributions in the CFDS-FLOW3D output printer file.

Total decay heat is $4.686 \mathrm{~W}$. All other cases have a total decay heat of $4.72 \mathrm{~W}$. 
Table 13. CFDS-FLOW3D conservative ${ }^{a}$ steady-state temperatures at each state of draining the $\mathrm{ACB}^{b}$

\begin{tabular}{|c|c|c|c|c|c|c|c|c|c|}
\hline $\begin{array}{l}\text { Distance } \\
\text { drained } \\
\text { (in.) }\end{array}$ & $\begin{array}{l}\text { Maximum } \\
\text { centerline } \\
\text { temperature } \\
\quad\left({ }^{\circ} \mathrm{F}\right)\end{array}$ & $\begin{array}{l}\text { Distance } \\
\text { below } \\
\text { top of } \\
\text { charcoal } \\
\text { (in.) }\end{array}$ & $\begin{array}{l}\text { Location } \\
\text { relative to } \\
\text { current waterline } \\
\text { (in.) }\end{array}$ & $\begin{array}{l}\text { Maximum } \\
\text { surface } \\
\text { temperature } \\
\left({ }^{\circ} \mathrm{F}\right)\end{array}$ & $\begin{array}{l}\text { Distance } \\
\text { relative } \\
\text { to top of } \\
\text { charcoal } \\
\text { (in.) }\end{array}$ & $\begin{array}{l}\text { Distance } \\
\text { above } \\
\text { current } \\
\text { waterline } \\
\text { (in.) }\end{array}$ & $\begin{array}{l}\mathrm{ACB} \\
\text { thermocouple } \\
\text { reading } \\
\left({ }^{\circ} \mathrm{F}\right)\end{array}$ & $\begin{array}{c}\text { Surface } \\
\text { temperature } \\
1 \text { in. above } \\
\text { waterline } \\
\left({ }^{\circ} \mathrm{F}\right)\end{array}$ & $\begin{array}{c}\text { Surface } \\
\text { temperature } \\
1 \text { in. below } \\
\text { waterline } \\
\left({ }^{\circ} \mathrm{F}\right)\end{array}$ \\
\hline 0 & 187.4 & 16.4 & -16.4 & 72.8 & 2.4 & 2.4 & 169.6 & 72.4 & 69.5 \\
\hline 4 & 187.3 & 16.4 & -12.4 & 79.9 & 0.4 & 4.4 & 173.0 & 77.2 & 70.5 \\
\hline 5 & 187.3 & 16.1 & -11.1 & 80.6 & -1.1 & 3.9 & 174.0 & 76.2 & 70.0 \\
\hline 15 & 206.0 & 9.2 & 5.8 & 90.5 & -7.1 & 7.9 & 188.0 & 80.6 & 70.7 \\
\hline 16 & 206.6 & 9.4 & 6.6 & 90.8 & -7.7 & 8.2 & 188.4 & 78.6 & 70.0 \\
\hline 29 & 211.2 & 14.2 & 14.8 & 93.5 & -14.3 & 14.7 & 189.8 & 78.5 & 68.9 \\
\hline 30 & 211.3 & 14.9 & 15.1 & 93.6 & -14.6 & 15.4 & 189.9 & 78.1 & 68.8 \\
\hline
\end{tabular}

${ }^{a}$ Conservative means high effective heat transfer coefficients used, which reduces pipe surface-to-air and -water temperature differences. If it is assumed that the ACB thermocouple is not reliable, then exceeding these temperature differences could result in the carbon centerline temperature exceeding the $100^{\circ} \mathrm{C}$ temperature limit.

${ }^{b}$ Results calculated using a uniform decay heat source $2.5 \mathrm{ft}$ long and $\mathrm{k}_{\text {charcoal }}=0.05 \mathrm{Btu} / \mathrm{h}-\mathrm{ft}-{ }^{\circ} \mathrm{F}$, based on the October 7 temperature measurements. (Four significant figures were used to show differences between the temperatures at each water level.) $\mathrm{T}_{\text {water }}=68^{\circ} \mathrm{F}, \mathrm{T}_{\text {air }}=70^{\circ} \mathrm{F}$. 
Best-estimate case:

and

$$
\text { for air, } C=0.4200
$$

$$
\text { for } \mathrm{CO}_{2} \quad \mathrm{C}=0.2899 \text {. }
$$

Conservative-estimate case:

and

for air, $C=0.4550$

$$
\text { for } \mathrm{CO}_{2}, \quad C=0.3769 \text {. }
$$

The comparisons between HEATING7.2 and CFDS-FLOW3D for four cases are presented in Table 14.

Table 14. Maximum steady-state carbon temperture for $\mathrm{ACB}$ filled with air or $\mathrm{CO}_{2}$

\begin{tabular}{|c|c|c|c|c|}
\hline \multirow{2}{*}{ Case } & \multicolumn{2}{|c|}{$\begin{array}{c}\text { Maximum carbon temperature in air } \\
\left({ }^{\circ} \mathrm{F}\right)\end{array}$} & $\begin{array}{r}\text { Maximum carbon temperature in } \mathrm{CO}_{2} \\
\left({ }^{\circ} \mathrm{F}\right)\end{array}$ \\
\cline { 2 - 5 } & HEATING7.2 & CFDS-FLOW3D & HEATING7.2 & CFDS-FLOW3D \\
\hline Best-estimate & 74.45 & 74.32 & 74.80 & 74.66 \\
\hline Conservative & 86.14 & 85.86 & 86.36 & 86.08 \\
\hline
\end{tabular}

As demonstrated in Table 14, there was good agreement between the HEATING7.2 and CFDSFLOW3D predictions with CFDS-FLOW3D slightly under predicting the HEATING results by 0.13 to $0.28^{\circ} \mathrm{F}$.

\subsection{TRANSIENT MODELS}

The CFDS-FLOW3D best-estimate and conservative steady-state water-draining models discussed in Sect. 6.1 were modified to run transient draining cases. The check calculations used the prescribed draining schedule shown in Fig. 17, and selected results for the first $26.0 \mathrm{~h}$ of the transient were compared to the HEATING7.2 results. Figure 18 presents a comparison of the time histories of the ACB thermocouple prediction for the HEATING7.2 and CFDS-FLOW3D simulations.

Tables 15 and 16 give CFDS-FLOW3D results for the best-estimate and conservative cases, respectively. Good agreement between the two models was observed for both cases.

\subsection{CELL-FILLING MODELS}

The benchmarking of the HEATING7.2 cell-filling models required that a new heat conduction model be built. Because CFDS-FLOW3D does not have the capability to simulate radiation and convection across gap regions (as required in the air and $\mathrm{CO}_{2}$ cases), the TOPAZ heat conduction $\operatorname{code}^{13}$ was selected for the check calculations. The MAZE code ${ }^{14}$ was employed to generate the required finite-element mesh. Using the vermiculite cases, three mesh refinement levels, ranging from 


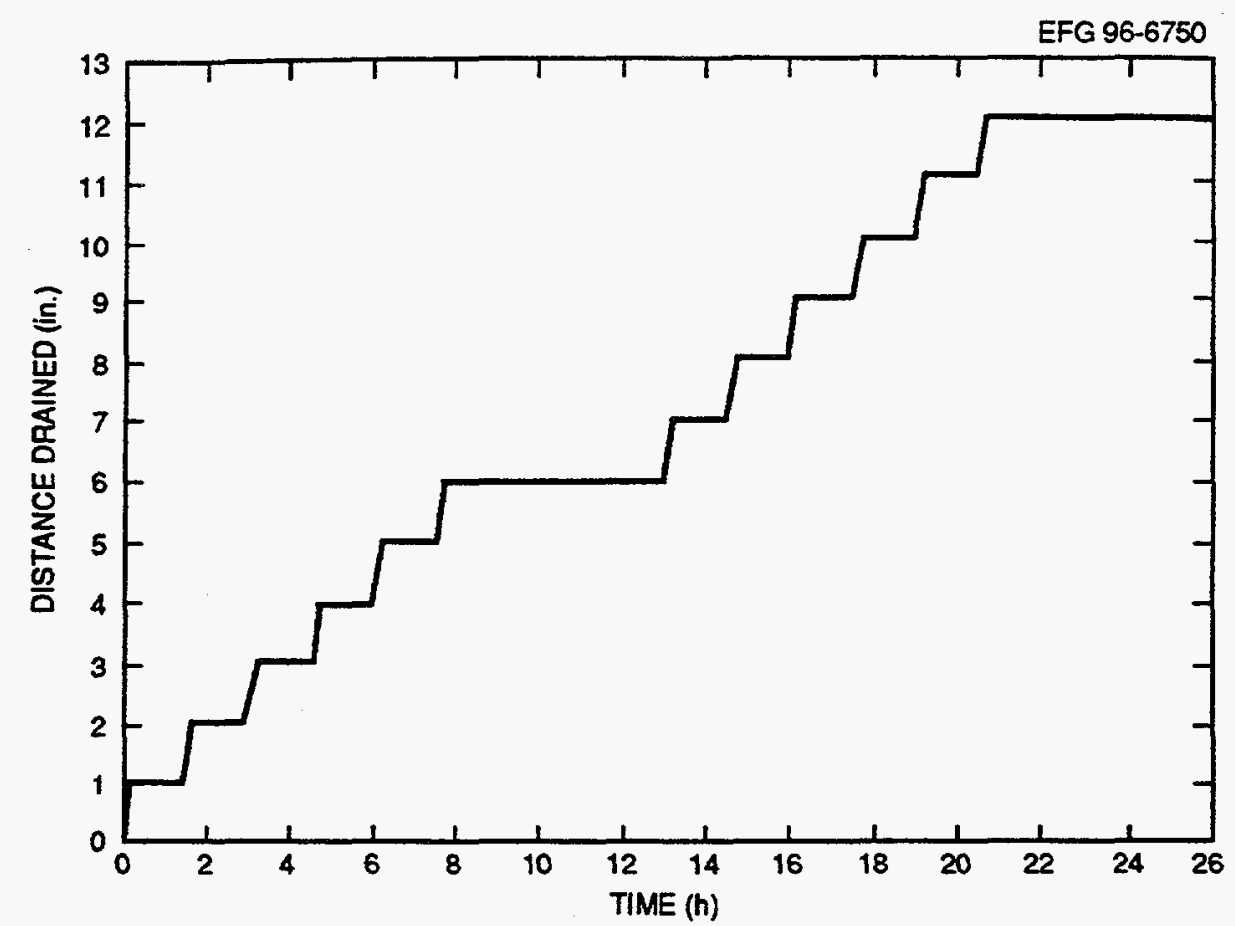

Fig. 17. Water level schedule for transient draining cases.

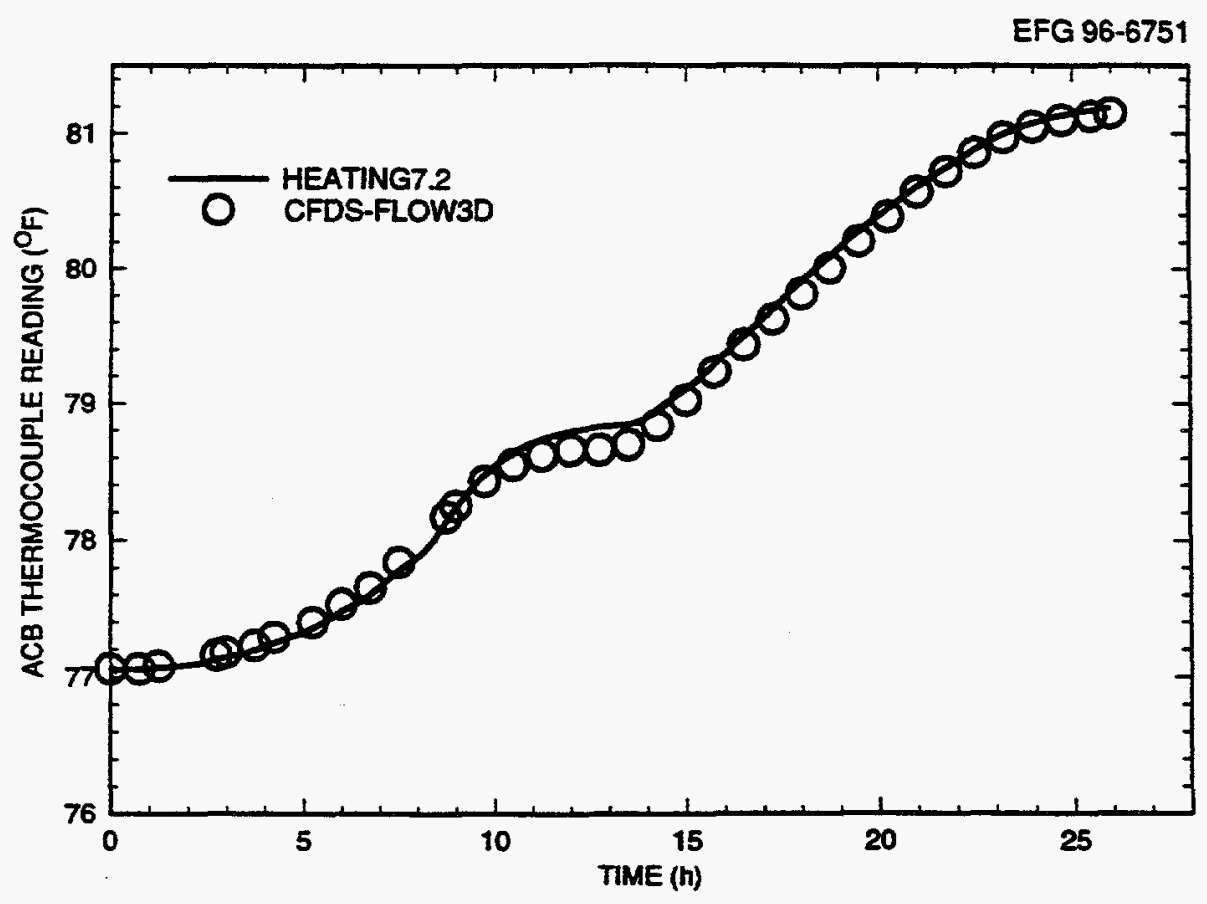

Fig. 18. Comparison of HEATING7.2 and CFDS-FLOW3D best-estimate transient-ACB thermocouple. 
Table 15. CFDS-FLOW3D best-estimate transient temperatures at each state of draining the $\mathrm{ACB}^{a}$

\begin{tabular}{|c|c|c|c|c|c|c|c|c|c|c|}
\hline $\begin{array}{l}\text { Time } \\
\text { (h) }\end{array}$ & $\begin{array}{l}\text { Distance } \\
\text { drained } \\
\text { (in.) }\end{array}$ & $\begin{array}{c}\text { Maximum } \\
\text { centerline } \\
\text { temperature } \\
\left({ }^{\circ} \mathrm{F}\right)\end{array}$ & $\begin{array}{l}\text { Distance } \\
\text { below } \\
\text { top of } \\
\text { charcoal }^{b} \\
\text { (in.) }\end{array}$ & $\begin{array}{l}\text { Location } \\
\text { relative to } \\
\text { current } \\
\text { waterline }^{b} \\
\text { (in.) }\end{array}$ & $\begin{array}{l}\text { Maximum } \\
\text { surface } \\
\text { temperature } \\
\left(^{\circ} \mathrm{F}\right)\end{array}$ & $\begin{array}{l}\text { Distance } \\
\text { relative } \\
\text { to top of } \\
\text { charcoal }^{b} \\
\text { (in.) }\end{array}$ & $\begin{array}{l}\text { Distance } \\
\text { above } \\
\text { current } \\
\text { waterline }^{b} \\
\text { (in.) }\end{array}$ & $\begin{array}{c}\mathrm{ACB} \\
\text { thermocouple } \\
\text { reading } \\
\left({ }^{\circ} \mathrm{F}\right)\end{array}$ & $\begin{array}{c}\text { Surface } \\
\text { temperature } \\
1 \text { in. above } \\
\text { waterline } \\
\left({ }^{\circ} \mathrm{F}\right)\end{array}$ & $\begin{array}{c}\text { Surface } \\
\text { temperature } \\
1 \text { in. below } \\
\text { waterline } \\
\left({ }^{\circ} \mathrm{F}\right)\end{array}$ \\
\hline 1.25 & 1 & 78.3 & 16.4 & -15.4 & 69.5 & 2.3 & 3.3 & 77.2 & 69.2 & 68.4 \\
\hline 2.75 & 2 & 78.3 & 16.5 & -14.5 & 69.9 & 2.3 & 4.3 & 77.2 & 69.4 & 68.4 \\
\hline 4.25 & 3 & 78.3 & 16.4 & -13.4 & 70.4 & 2.3 & 5.3 & 77.4 & 69.6 & 68.5 \\
\hline 5.75 & 4 & 78.3 & 16.3 & -12.3 & 70.8 & 2.3 & 6.3 & 77.5 & 69.8 & 68.5 \\
\hline 7.25 & 5 & 78.3 & 16.4 & -11.4 & 71.1 & 1.0 & 6.0 & 77.8 & 69.9 & 68.5 \\
\hline 8.75 & 6 & 78.4 & 7.4 & -1.3 & 71.4 & 0.5 & 6.5 & 78.2 & 70.0 & 68.5 \\
\hline 13.0 & 6 & 78.8 & 6.9 & -0.9 & 71.6 & 0.4 & 6.4 & 78.7 & 70.1 & 68.5 \\
\hline 14.25 & 7 & 78.9 & 6.9 & 0.1 & 71.7 & -1.1 & 5.8 & 78.8 & 70.3 & 68.6 \\
\hline 15.75 & 8 & 79.4 & 6.8 & 1.2 & 71.9 & -1.6 & 6.4 & 79.2 & 70.2 & 68.5 \\
\hline 17.25 & 9 & 79.8 & 6.8 & 2.2 & 72.1 & -2.1 & 6.9 & 79.6 & 70.0 & 68.5 \\
\hline 18.75 & 10 & 80.3 & 6.8 & 3.2 & 72.4 & -2.7 & 7.3 & 80.0 & 70.2 & 68.5 \\
\hline 20.25 & 11 & 80.8 & 6.8 & 4.1 & 72.6 & -3.2 & 7.8 & 80.4 & 70.2 & 68.5 \\
\hline 21.75 & 12 & 81.2 & 7.1 & 4.9 & 72.7 & -3.6 & 8.4 & 80.8 & 70.2 & 68.5 \\
\hline 26.0 & 12 & 81.8 & 7.1 & 4.9 & 72.8 & -4.0 & 8.0 & 81.2 & 70.2 & 68.5 \\
\hline
\end{tabular}

${ }^{a}$ Results calculated using a uniform decay heat source $2.5 \mathrm{ft}$ long and $\mathrm{k}_{\text {charcoal }}=0.05 \mathrm{Btu} / \mathrm{h}-\mathrm{ft}-{ }^{\circ} \mathrm{F}$, based on the October 7 temperature measurements. (Three significant figures were used to show differences between the temperatures at each water level.) $\mathrm{T}_{\text {water }}=68^{\circ} \mathrm{F}, \mathrm{T}_{\text {air }}=70^{\circ} \mathrm{F}$.

${ }^{b}$ Distances are best estimates based on resolution (three significant figures) of temperature distributions in the CFDS-FLOW3D output printer file. 
Table 16. CFDS-FLOW3D conservative ${ }^{a}$ transient temperatures at each state of draining the $\mathrm{ACB}^{b}$

\begin{tabular}{|c|c|c|c|c|c|c|c|c|c|c|}
\hline $\begin{array}{l}\text { Time } \\
\text { (h) }\end{array}$ & $\begin{array}{c}\text { Distance } \\
\text { drained } \\
\text { (in.) }\end{array}$ & $\begin{array}{c}\text { Maximum } \\
\text { centerline } \\
\text { temperature } \\
\left({ }^{\circ} \mathrm{F}\right)\end{array}$ & $\begin{array}{l}\text { Distance } \\
\text { below } \\
\text { top of } \\
\text { charcoal } \\
\text { (in.) }\end{array}$ & $\begin{array}{l}\text { Location } \\
\text { relative to } \\
\text { current } \\
\text { waterline } \\
\text { (in.) }\end{array}$ & $\begin{array}{l}\text { Maximum } \\
\text { surface } \\
\text { temperature } \\
\left({ }^{\circ} \mathrm{F}\right)\end{array}$ & $\begin{array}{l}\text { Distance } \\
\text { relative } \\
\text { to top of } \\
\text { charcoal } \\
\text { (in.) }\end{array}$ & $\begin{array}{l}\text { Distance } \\
\text { above } \\
\text { current } \\
\text { waterline } \\
\text { (in.) }\end{array}$ & $\begin{array}{l}\mathrm{ACB} \\
\text { thermocouple } \\
\text { reading } \\
\left({ }^{\circ} \mathrm{F}\right)\end{array}$ & $\begin{array}{c}\text { Surface } \\
\text { temperature } \\
1 \text { in. above } \\
\text { waterline } \\
\left({ }^{\circ} \mathrm{F}\right)\end{array}$ & $\begin{array}{c}\text { Surface } \\
\text { temperature } \\
1 \text { in. below } \\
\text { waterline } \\
\left({ }^{\circ} \mathrm{F}\right)\end{array}$ \\
\hline 1.25 & 1 & 187.4 & 16.4 & -15.4 & 75.1 & 2.3 & 3.3 & 169.8 & 74.0 & 70.0 \\
\hline 2.75 & 2 & 187.3 & 16.7 & -14.7 & 76.2 & 1.9 & 3.9 & 170.1 & 73.7 & 69.8 \\
\hline 4.25 & 3 & 187.3 & 16.7 & -13.7 & 78.1 & 0.7 & 3.7 & 170.6 & 75.4 & 70.0 \\
\hline 5.75 & 4 & 187.3 & 16.7 & -12.7 & 79.7 & 0.3 & 4.3 & 171.5 & 77.0 & 70.4 \\
\hline 7.25 & 5 & 187.3 & 16.7 & -11.7 & 80.5 & -1.2 & 3.8 & 172.8 & 76.3 & 70.0 \\
\hline 8.75 & 6 & 187.3 & 16.4 & -10.4 & 82.3 & -2.1 & 3.9 & 174.4 & 77.8 & 70.3 \\
\hline 13.0 & 6 & 187.3 & 14.4 & -8.4 & 82.5 & -2.1 & 3.8 & 176.6 & 77.9 & 70.3 \\
\hline 14.25 & 7 & 187.5 & 8.6 & -1.6 & 83.9 & -3.0 & 4.0 & 177.3 & 78.8 & 70.6 \\
\hline 15.75 & 8 & 188.8 & 7.8 & 0.2 & 84.7 & -3.0 & 5.0 & 179.0 & 77.3 & 70.0 \\
\hline 17.25 & 9 & 190.9 & 7.8 & 1.2 & 85.9 & -3.8 & 5.2 & 180.6 & 78.1 & 70.2 \\
\hline 18.75 & 10 & 193.6 & 7.7 & 2.2 & 86.9 & -4.3 & 5.7 & 182.4 & 79.0 & 70.2 \\
\hline 20.25 & 11 & 196.2 & 7.8 & 3.2 & 87.8 & -4.7 & 6.2 & 183.9 & 79.4 & 70.4 \\
\hline 21.75 & 12 & 198.6 & 8.2 & 3.8 & 88.6 & -5.7 & 6.3 & 185.2 & 80.1 & 70.6 \\
\hline 26.0 & 12 & 201.6 & 8.4 & 3.6 & 88.9 & -5.7 & 6.3 & 186.7 & 80.2 & 70.7 \\
\hline
\end{tabular}

${ }^{a}$ Conservative means high effective heat transfer coefficients used, which reduces pipe surface-to-air and -water temperature differences. If it is assumed that the ACB thermocouple is not reliable, then exceeding these temperature differences could result in the carbon centerline temperature exceeding the $100^{\circ} \mathrm{C}$ temperature limit.

${ }^{b}$ Results calculated using a uniform decay heat source $2.5 \mathrm{ft}$ long and $\mathrm{k}_{\text {charcoal }}=0.05 \mathrm{Btu} / \mathrm{h}-\mathrm{ft}-{ }^{\circ} \mathrm{F}$, based on the October 7 temperature measurements. (Four significant figures were used to show differences between the temperatures at each water level.) $\mathrm{T}_{\text {water }}=68^{\circ} \mathrm{F}, \mathrm{T}_{\text {air }}=70^{\circ} \mathrm{F}$. 
1288 to 4992 nodes, were examined to ensure a mesh-independent solution. Six cases were run corresponding to the best-estimate and conservative conditions for a shield plug upper surface temperature of $110^{\circ} \mathrm{F}$. The comparisons are presented in Table 17. As shown in Table 17, there was good agreement between the HEATING7.2 and TOPAZ models with TOPAZ underpredicting the HEATING results by 0.24 to $1.4^{\circ} \mathrm{F}$.

Table 17. Comparison of HEATING7.2 and TOPAZ results for cell-filling models

\begin{tabular}{|c|c|c|c|c|}
\hline \multirow{2}{*}{ Case } & \multicolumn{4}{|c|}{ Maximum carbon temperatures $\left({ }^{\circ} \mathrm{F}\right)$} \\
\cline { 2 - 5 } & \multicolumn{2}{|c|}{ Best-Estimate } & \multicolumn{2}{c|}{ Conservative } \\
\cline { 2 - 5 } & HEATING & TOPAZ & HEATING & TOPAZ \\
\hline Air & 102.60 & 101.2 & 115.29 & 115.0 \\
\hline $\mathrm{CO}_{2}$ & 102.75 & 101.6 & 115.53 & 115.2 \\
\hline Vermiculite & 126.24 & 126.0 & 155.23 & 154.8 \\
\hline
\end{tabular}





\section{CONCLUSIONS}

All the thermal analysis conducted in support of the MSRE remediation project can be summarized by the following conclusions.

1. Thermal conditions inside the MSRE charcoal column could not be characterized based on the single thermocouple already mounted in the bed.

2. Development of a thermocouple probe for taking additional temperature measurements was necessary to assess the thermal situation. After mock-up testing to quantify uncertainties, the measurements could be interpreted accurately enough to give valuable results.

3. Probe data in water allowed a reasonable calculation of the heat source present in the pipe.

4. The best-estimate temperature results from steady-state calculations were well below the agreed limit of $100^{\circ} \mathrm{C}$, provided the heat generation is homogeneous and does not increase with temperature. They quite accurately predicted the actual temperature increase observed during draining of the charcoal bed.

5. The limiting case temperatures were high enough above the best-estimate predictions to have been detected and provide a warning of trouble during the draining process.

6. Transient calculations showed the proposed draining procedure involving a $\mathrm{l}-\mathrm{h}$ waiting period was sufficiently slow that excessive thermal lag would not accumulate during the process.

7. After the water had been drained, thermocouple probe measurements in air showed larger and more distinct surface temperature differences than could be observed in water. Thus, the air data provided a more accurate picture of the heat source than was previously available.

8. Filling the $\mathrm{CBC}$ with $\mathrm{CO}_{2}$ would make essentially no difference in the charcoal temperatures present under air cooling. Filling the $C B C$ with vermiculite does lead to some increase in the charcoal temperatures, but the charcoal remains well below $100^{\circ} \mathrm{C}$.

9. All the above results have been verified for accuracy by both hand calculations and independent numerical modeling. 


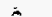




\section{REFERENCES}

1. J. E. Rushton et al., Molten Salt Reactor Experiment Remediation Project Review (Vol. 1), presentation for the MSRE Senior Review Board, Martin Marietta Energy Systems, Inc., Oak Ridge Natl. Lab., February 1995.

2. K. W. Childs, HEATING7.2 User's Manual, ORNL/TM-12262, Martin Marietta Energy Systems, Inc., Oak Ridge Natl. Lab., February 1993.

3. E. Glueckauf and R. E. Watts, Heat Conduction in Charcoal Columns, Atomic Energy Research Establishment, Harwell, United Kingdom, 1958.

4. P. N. J. Henrion and W. Claes, "Thermal Conductivity Measurements in Charcoal Beds near Room Temperature," Powder Technol., 19, 289-91 (1978).

5. O. M. M. Eltom and A. A. M. Sayigh, "A Simple Method to Enhance Thermal Conductivity of Charcoal Using Some Additives," Renewable Energy, 4, 113-18 (1994).

6. H. Schlichting, Boundary-Layer Theory, 7th ed., McGraw-Hill Book Company, New York, 1979 , pp. 315-21.

7. F. P. Incropera and D. P. DeWitt, Fundamentals of Heat and Mass Transfer, 3rd ed., John Wiley and Sons, New York, 1990, pp. 536-54.

8. W. M. Rohsenow and H. Choi, Heat, Mass, and Momentum Transfer, Prentice-Hall, Inc., Englewood Cliffs, New Jersey, 1961, pp. 202-04.

9. CFDS-FLOW3D: Release 3.3 Users Manual, Computational Fluid Dynamics Services, Harwell Laboratory, Oxfordshire, United Kingdom, June 1994.

10. E. M. Sparrow and J. L. Gregg, "Laminar Free Convection Heat Transfer from the Outer Surface of a Vertical Circular Cylinder," Trans. ASME, 78, 1823-29 (1956).

11. Y. S. Touloukian et al., Thermophysical Properties of Matter (Vol. 2, Thermal Conductivity of Nonmetallic Solids), IFL/Plenum, New York, 1970, pp. 823-26.

12. K. Labs, Regional Analysis of Ground and Above-Ground Climate, ORNL/Sub-81/40451/1, Union Carbide Corp., Nucl. Div., Oak Ridge Natl. Lab., December 1981.

13. A. B. Shapiro, TOPAZ-A Finite Element Heat Conduction Code for Analyzing 2-D Solids, UCID-20045, Lawrence Livermore Natl. Lab., March 1984.

14. J. O. Hallquist, MAZE - An Input Generator for DYNA2D and NIKE2D, UCID-19029, Rev. 1, Lawrence Livermore Natl. Lab., March 1982. 
Appendix A

SAMPLE FINALIZED HEATING7.2 MODEL 


\section{3}




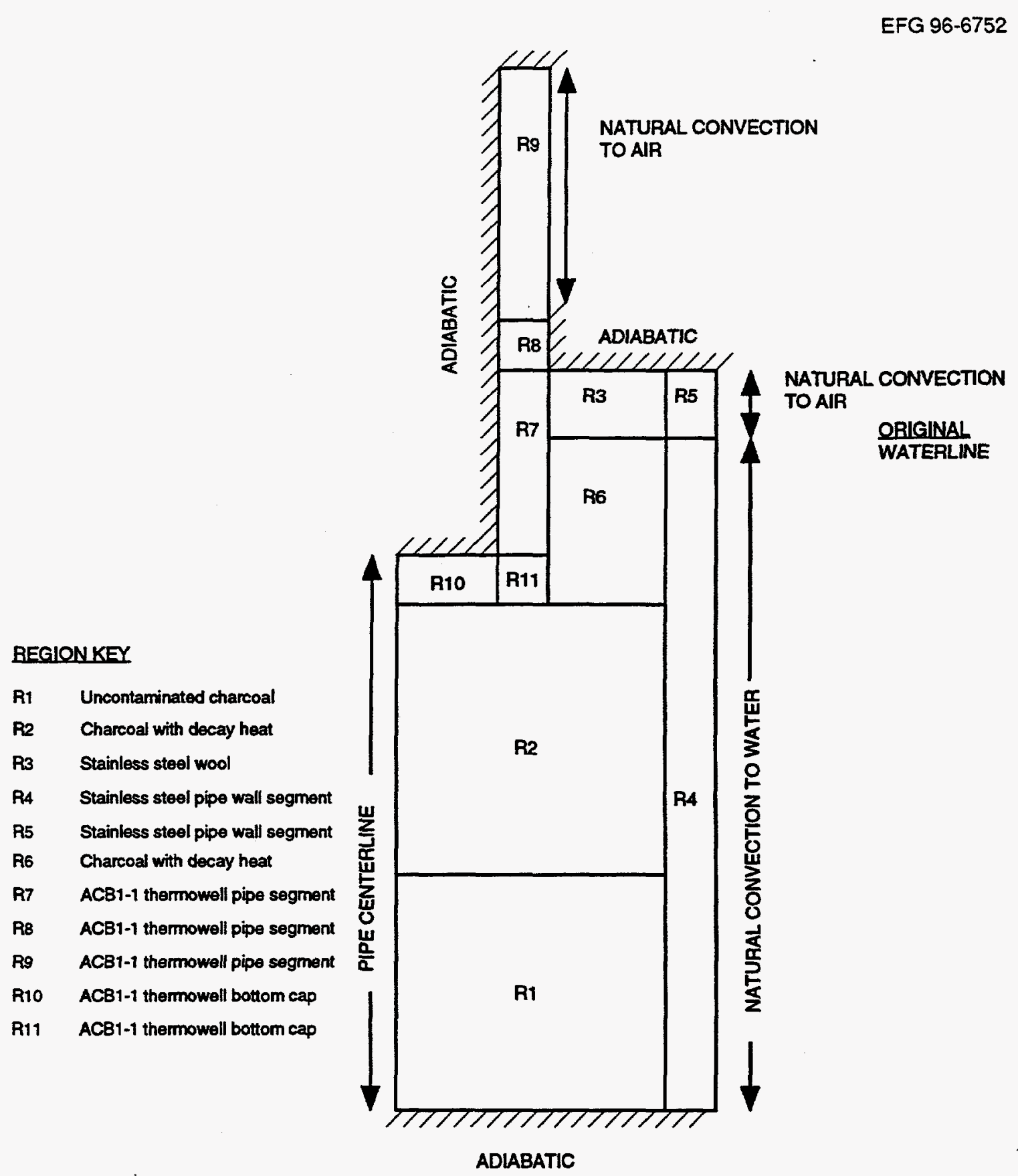

Fig. A.1a. Schematic of a finalized, best-estimate HEATING7.2 model showing the initial waterline and ACB1-1 thermowell. (Not drawn to scale) 
Steady-state solution including the effect of T/C well pipe

* A vertical pipe packed with graphite is surrounded by water.

* Over a period of time, some combination of uranium, fluorine,

* and graphite has reacted (inhomogeneously), creating heat

* generation due to the chemical reactions and additional heat

* from radioactive decay. The distribution of these heat

* sources is not known, so some plausible alternatives will

* be tested.

* The intent is to remove the water from outside the pipe,

* lessening the nuclear criticality problem but making the

* heat removal problem more difficult, because the heat

* previously removed by natural convection of water must

* now be removed by natural convection of air.

* "Customary Units" - BTU, F, FT, HR, LBm

$\begin{array}{llll}500 & 3 & 0 & 0\end{array}$

REGIONS

$\begin{array}{lllllllll}1 & 1 & 0.0 & 0.26488 & 0.0 & 0.0 & -1.5833 & -0.0833\end{array}$

$\begin{array}{llllllll}1 & 0 & 0 & 0 & 0 & 0 & 1 & 0\end{array}$

$\begin{array}{llll}2 & 1 & 0.0\end{array}$

$\begin{array}{lllll}0.26488 & 0.0 & 0.0 & -0.0833 & 1.9167\end{array}$

$\begin{array}{llllllll}1 & 1 & 0 & 0 & 0 & 0 & 0 & 0\end{array}$

$\begin{array}{llll}3 & 2 & 0.016875\end{array}$

$\begin{array}{llllllll}1 & 0 & 0 & 0 & 0 & 0 & 0 & 1\end{array}$

$\begin{array}{llll}4 & 3 & 0.26488\end{array}$

$\begin{array}{lllll}0.26488 & 0.0 & 0.0 & 2.4167 & 2.6250\end{array}$

$\begin{array}{llllllll}1 & 0 & 0 & 2 & 0 & 0 & 1 & 0\end{array}$

$\begin{array}{lll}5 & 3 & 0.26488\end{array}$

$\begin{array}{llllllll}1 & 0 & 0 & 3 & 0 & 0 & 0 & 1\end{array}$

610.016875

11

$\begin{array}{llllll}0.27604 & 0.0 & 0.0 & -1.5833 & 2.4167\end{array}$

$\begin{array}{lllll}0.27604 & 0.0 & 0.0 & 2.4167 & 2.6250\end{array}$

$\begin{array}{lllll}0.26488 & 0.0 & 0.0 & 1.9167 & 2.4167\end{array}$

730.011208

$\begin{array}{lllll}0.016875 & 0.0 & 0.0 & 1.9219 & 2.6250\end{array}$

$\begin{array}{lll}1 & 0 & 1\end{array}$

$\begin{array}{lll}8 & 3 & 0.011208\end{array}$

$\begin{array}{lllll}0.016875 & 0.0 & 0.0 & 2.6250 & 2.7917\end{array}$

$\begin{array}{llll}1 & 0 & 1 & 1\end{array}$

$\begin{array}{lll}1 & 3 & 0.011208\end{array}$

$\begin{array}{llllllll}1 & 0 & 1 & 3 & 0 & 0 & 0 & 1\end{array}$

$\begin{array}{lll}103 & 0.0\end{array}$

$\begin{array}{llllllll}1 & 0 & 0 & 0 & 0 & 0 & 0 & 1\end{array}$

1130.011208

$\begin{array}{lllll}0.016875 & 0.0 & 0.0 & 2.7917 & 4.3750\end{array}$

$\begin{array}{llll}0.011208 & 0.00 .0 & 1.9167 & 1.9219\end{array}$

10

0.0168750 .00 .0

$1.9167 \quad 1.9219$

BOUNDARY

1168.0

$\begin{array}{llllllll}1.0 \mathrm{e}-8 & 0.0 & 0.0 & 0.0 & 0.0 & 0\end{array}$

2168.0

$\begin{array}{llllll}0.0 & 0.0 & 19.0850 & 0.25 & 0.0 & 0\end{array}$

3170.0

$\begin{array}{llllll}0.0 & 8.57 \mathrm{e}-10 & 0.4642 & 0.25 & 0.0 & 0\end{array}$

MATERIALS

1 carbon $0.05 \quad 33.08680 .1694$

2 steelwol $0.62 \quad 4.9318 \quad 0.1139$

$3 * 31333$

INITIAL

184.0

HEAT

129.043

XGRID

$\begin{array}{lllll}0.0 & 0.011208 & 0.016875 & 0.26488 & 0.27604\end{array}$

$\begin{array}{llll}2 & 3 & 10 & 2\end{array}$

ZGRID

$-1.58336^{-0.0833} 46^{1.9167} 2^{1.9219} 2.00002 .41672^{2.6250}{ }_{4}^{2.7917} 4.3750$

NODES

11513

STEADY

2

$\%$

Fig. A.1b. HEATING7.2 input file for the model in Fig. A.1a. 
ORNL/TM-13026

Dist.Category UC-902

\section{INTERNAL DISTRIBUTION}

1. R. N. Borum

2. S. N. Burman

3. R. M. Canon

4. K. W. Childs

5. W. G. Craddick

6. A. G. Croff

7. G. D. Del Cul

8. M. F. P. DeLozier

9. J. R. Devore

10. R. L. Faulkner

11. M. K. Ford

12. R. G. Gilliland

13. M. A. Green

14. D. M. Hetrick

15. E. M. Hodges

16. J. S. Ivey

17. J. R. Keiser

18. B. L. Kimmel

19. M. A. Kuliasha

20. L. E. McNeese

21. G. T. Mei

22-24. D. G. Morris

25. D. E. Mueller

26. J. E. Park

27. S. H. Park

\author{
28-32. B. D. Patton \\ 33. F. J. Peretz \\ 34. D. W. Ramey \\ 35. J. P. Renier \\ 36. J. C. Rudolph \\ 37. J. E. Rushton \\ 38. G. W. Sherrill \\ 39. C. C. Southmayd \\ 40. J. O. Stiegler \\ 41-45. C. D. Sulfredge \\ 46. R. M. Szozda \\ 47. L. M. Toth \\ 48. L. D. Trowbridge \\ 49. K. L. Walker \\ 50. D. F. Williams \\ 51. P. T. Williams \\ 52. G. L. Yoder, Jr. \\ 53. ER Document Management Center \\ 54. Central Research Library \\ 55. Y-12 Technical Library \\ Document Reference Center \\ 56. ORNL Patent Section \\ 57-58. ORNL Laboratory Records \\ 59. ORNL Laboratory Records RC
}

\section{EXTERNAL DISTRIBUTION}

60. E. C. Crume, Jr., Pragmatics Inc., 708 S. Illinois Avenue, Suite E105, Oak Ridge, TN 37830

61. J. R. Engel, 118 E. Morningside Drive, Oak Ridge, TN 37830

62. M. R. Jugan, Environmental Restoration, Department of Energy, Oak Ridge Operations, P. O. Box 2001, Oak Ridge, TN 37831

63. N. W. Lingle, Environmental Restoration, Department of Energy, Oak Ridge Operations, P. O. Box 2001, Oak Ridge, TN 37831

64. K. J. Notz, Henley Point-River Road, Kingston, TN 37763

65. L. P. Pugh, 2024 Cedar Lane, Kingston, TN 37763

66. Office of Assistant Manager for Energy Research and Development, Department of Energy, Oak Ridge Operations, P. O. Box 2001, Oak Ridge, TN 37831

67-194. Office of Scientific and Technical Information, P. O. Box 62, Oak Ridge, TN 37831. Given distribution as shown in DOE/OSTI-4500-R75, under category UC-902. 